\title{
An integrative monograph of Carex section Schoenoxiphium (Cyperaceae)
}

\author{
Modesto Luceño ${ }^{\text {Corresp., } 1}$, Tamara Villaverde ${ }^{\text {Corresp., } 1,2}{ }^{2}$, José Ignacio Márquez-Corro ${ }^{1}$, Rogelio Sánchez-Villegas ${ }^{1}$, \\ Enrique Maguilla $^{3}{ }$, Marcial Escudero ${ }^{3}$, Pedro Jiménez-Mejías ${ }^{4}$, Manuel Sánchez-Villegas ${ }^{1}$, Mónica Míguez ${ }^{1}$, \\ Carmen Benítez-Benítez ${ }^{1}$, Abraham Muthama Muasya ${ }^{5}$, Santiago Martín-Bravo ${ }^{1}$ \\ ${ }^{1}$ Department of Molecular Biology and Biochemical Engineering , Botany area, Universidad Pablo de Olavide, Seville, Seville, Spain \\ 2 Department of Biology and Geology, Universidad de Almería, Almería, Almería, Spain \\ 3 Department of Plant Biology and Ecology, Universidad de Sevilla, Seville, Seville, Spain \\ 4 Department of Biology, Botany area, Universidad Autónoma de Madrid, Madrid, Madrid, Spain \\ 5 Department of Biological Sciences, Bolus Herbarium, University of Cape Town, Cape Town, South Africa, South Africa \\ Corresponding Authors: Modesto Luceño, Tamara Villaverde \\ Email address: mlucgar@upo.es, tvilhid@gmail.com
}

Carex section Schoenoxiphium (Cariceae, Cyperaceae) is endemic to the Afrotropical biogeographic region and is mainly distributed in southern and eastern Africa, with its center of diversity is eastern South Africa. The taxon was formerly recognized as a distinct genus and has a long history of taxonomic controversy. It has also an important morphological and molecular background in particular dealing with the complexity of its inflorescence and the phylogenetic relationships of its species. We here present a fully updated and integrative monograph of Carex section Schoenoxiphium based on morphological, molecular and cytogenetic data. A total of 1,017 herbarium specimens were examined and the majority of the species were studied in the field. Previous molecular phylogenies based on Sanger-sequencing of four DNA nuclear and plastid regions and RAD-seq were expanded. For the first time, chromosome numbers were obtained, with cytogenetic counts on 44 populations from 15 species and one hybrid. Our taxonomic treatment recognizes 21 species, one of them herein newly described ( $C$. gordon-grayae). Our results agree with previous molecular works that have found five main lineages in Schoenoxiphium. We provide detailed morphological descriptions, distribution maps and analytical drawings of section Schoenoxiphium and all accepted species, an identification key, and a thorough nomenclatural survey including 19 new typifications and one nomen novum. 


\section{An integrative monograph of Carex section 2 Schoenoxiphium (Cyperaceae)}

3

4

5

6 7

8

9
Modesto Luceño ${ }^{1 *}$, Tamara Villaverde ${ }^{2 *}$, José Ignacio Márquez-Corro ${ }^{1}$, Rogelio SánchezVillegas $^{1}$, Enrique Maguilla ${ }^{3}$, Marcial Escudero ${ }^{3}$, Pedro Jiménez-Mejías ${ }^{4}$, Manuel Sánchez-

Villegas ${ }^{1}$, Mónica Míguez ${ }^{1}$, Carmen Benítez-Benítez ${ }^{1}$, Abraham Muthama Muasya ${ }^{5} \&$ Santiago Martín-Bravo ${ }^{1}$

${ }^{1}$ Department of Molecular Biology and Biochemical Engineering, Botany area, Universidad Pablo de Olavide, Seville, Spain

${ }^{2}$ Department of Biology and Geology, Universidad de Almería, Almería, Spain

${ }^{3}$ Department of Plant Biology and Ecology, Universidad de Sevilla, Seville, Spain

${ }^{4}$ Department of Biology, Botany area, Biological Sciences Faculty, Universidad Autónoma de Madrid, Madrid, Spain

${ }^{5}$ Bolus Herbarium, Department of Biological Sciences, University of Cape Town, Cape Town, South Africa

Corresponding Author:

Modesto Luceño ${ }^{1}$

Tamara Villaverde ${ }^{2}$

${ }^{1}$ Department of Molecular Biology and Biochemical Engineering, Botany area, Universidad Pablo de Olavide, Seville, Spain

${ }^{2}$ Department of Biology and Geology, Universidad de Almería, Almería, Spain

Email addresses: mlucgar@upo.es, tvilhid@gmail.com 
30

31

32

33

34

35

36

37

38

39

40

41

42

43

44

45

46

47

48

49

50

51

52

53

54

55

56

57

58

59

60

61

62

63

64

65

66

67

68

69

\section{Abstract}

Carex section Schoenoxiphium (Cariceae, Cyperaceae) is endemic to the Afrotropical biogeographic region and is mainly distributed in southern and eastern Africa, with its center of diversity is eastern South Africa. The taxon was formerly recognized as a distinct genus and has a long history of taxonomic controversy. It has also an important morphological and molecular background in particular dealing with the complexity of its inflorescence and the phylogenetic relationships of its species. We here present a fully updated and integrative monograph of Carex section Schoenoxiphium based on morphological, molecular and cytogenetic data. A total of 1,017 herbarium specimens were examined and the majority of the species were studied in the field. Previous molecular phylogenies based on Sanger-sequencing of four DNA nuclear and plastid regions and RAD-seq were expanded. For the first time, chromosome numbers were obtained, with cytogenetic counts on 44 populations from 15 species and one hybrid. Our taxonomic treatment recognizes 21 species, one of them herein newly described (C. gordongrayae). Our results agree with previous molecular works that have found five main lineages in Schoenoxiphium. We provide detailed morphological descriptions, distribution maps and analytical drawings of section Schoenoxiphium and all accepted species, an identification key, and a thorough nomenclatural survey including 19 new typifications and one nomen novum.

\section{Introduction}

Carex L. is a member of the grass-like plant family Cyperaceae (sedges). This hyperdiverse genus is one the three largest plant genera, with around 2000 accepted species, which also makes it larger than 90\% of plant families (Escudero et al., 2012; Global Carex Group, 2015; JiménezMejías et al., 2016; Govaerts et al., 2020). Carex has a nearly cosmopolitan distribution, with higher species richness in cold-temperate regions of the Northern Hemisphere and lower species numbers in the Southern Hemisphere, especially at tropical latitudes. In particular, the Afrotropical biogeographic realm is the poorest one in terms of Carex species, with 111 species (Martín-Bravo et al., 2019). Nonetheless, important hotspots of Carex diversity and endemicity are found in southern Africa and Madagascar, which harbour the highest number of species in Sub-Saharan Africa (Govaerts et al., 2020; Larridon et al., 2021). An important proportion of South African's Carex diversity corresponds to section Schoenoxiphium (Nees) Baillon, which is considered one of the few examples of an in-situ radiation of the genus in the Afrotropical region (Martín-Bravo et al., 2019; Márquez-Corro et al., 2020).

\section{$\underline{\text { Taxonomic and systematic background }}$}

Schoenoxiphium was traditionally considered a distinct Cyperaceae genus (Nees, 1832), and the most primitive within tribe Cariceae on the basis of inflorescence structure (Kükenthal, 1909, 1910). Its relationship with other Cariceae lineages (e.g. former genus Kobresia Willd. and subgenus Vigneastra (Tuckerman) Kük.) based on morphology have long remained controversial (see Gehrke et al., 2010). However, the former genus Schoenoxiphium has been subsumed within 
70 Carex (Global Carex Group, 2015) together with three other satellite genera (Cymophyllus Mack.

71 ex Britton \& A.Br., Kobresia and Uncinia Pers.), after molecular phylogenies demonstrated that 72 they were all nested within a paraphyletic Carex (e.g. Waterway \& Starr, 2007; Starr \& Ford, 73 2009; Waterway, Hoshino \& Masaki, 2009). Subsequently, the support of former genus 74 Schoenoxiphium's monophyly (Gehrke et al., 2010; Villaverde et al., 2017), together with its 75 morphological synapomorphies led to the proposal of considering it as a Carex section 76 (Villaverde et al., 2017). Recent phylogenetic evidence (Jiménez-Mejías et al., 2016; Martín77 Bravo et al., 2019, Villaverde et al., 2020) indicates that section Schoenoxiphium is placed in 78 subgenus Psyllophorae (Degland) Peterm., a main Carex lineage that also contains a small

79

80

81

82

83

84

85

86

87

88

89

90

91

92

93

94

95

96

97

98

99

100

101

102

103

104

105

106

107

108 number of other species (e.g. C. andina Phil. clade, C. distachya Desf. clade; Gehrke et al., 2010; Villaverde et al., 2017; Roalson et al., 2020). The subgeneric classification of Carex has recently been rearranged following a genomic Hyb-Seq Carex phylogeny (Villaverde et al., 2020). Previous molecular phylogenies focused on section Schoenoxiphium were based on a relatively small number of DNA regions (nuclear ITS and ETS; plastid trnL-F, matK and rps 16). They found a well-supported internal phylogenetic backbone composed of five strongly supported main clades (Clades A-E; Gehrke et al., 2010; Villaverde et al., 2017; Márquez-Corro et al., 2020), although species relationships remained partially unresolved, sometimes suggesting the existence of cryptic species, which have been recently described (Márquez-Corro et al., 2017; this study). Furthermore, the available phylogenetic evidence suggests a complex evolutionary history, as illustrated by a documented case of intersectional hybridization followed by recombination involving section Schoenoxiphium (Clade C) and another member of subgenus Psyllophorae (C. camptoglochin V.I.Krecz., section Junciformes) (Gehrke et al., 2010). Molecular phylogenies have also revealed that $C$. acocksii C. Archer, a poorly known unispicate species with remarkable morphological, molecular, biogeographical and ecological differentiation, unexpectedly belongs to the section Schoenoxiphium (Márquez-Corro et al., 2020). More recently, a phylogenomic approach based on RAD-seq has further helped to clarify the systematics of section Schoenoxiphium (Villaverde et al., 2021).

Taxonomy in section Schoenoxiphium is complex and characterized by long-standing problems regarding species circumscription and nomenclature (Villaverde et al., 2017). Thus, previous taxonomic treatments have considerably varied in the number of accepted species (6 in Kükenthal, 1909; 15 in Kukkonen, 1978, 1983, 1986, and in Gordon-Gray, 1995; c. 18-20 in recent phylogenetic studies: Gehrke et al., 2010; Villaverde et al., 2017; Márquez-Corro et al., 2020; Villaverde et al., 2021; see Table 1).

In addition, while the five main lineages detected by previous phylogenies are well-supported, there are no clear combinations of morphological synapomorphies characterizing them. Moreover, weak morphological boundaries and species non-monophyly are common patterns found within some lineages (e.g. Clades C, D and E; Villaverde et al., 2017). High phenotypic plasticity has also been suggested to be related with these delimitation problems (Márquez-Corro et al., 2017). Thus, conspicuous morphological differences (e.g. in organ size or inflorescence 
109

110

111

112

113

114

115

116

117

118

119

120

121

122

123

124

125

126

127

128

129

130

131

132

133

134

135

136

137

138

139

140

141

142

143

144

145

146

147

148

complexity) have been observed between populations of the same species growing at different altitudes (e.g. C. killickii Nelmes).

\section{Biogeographic and evolutionary patterns}

Section Schoenoxiphium is endemic to the Afrotropical biogeographic region, with a clear center of diversity in eastern South Africa. It is distributed in southern and eastern Africa, including Madagascar, and marginally reaches the mountains of SE Arabian Peninsula (Villaverde et al., 2017). Interestingly, the high species number of the section in South Africa makes this one of the few regions worldwide where the richest Carex group is not the large subgenus Carex, but another one, in this case subgenus Psyllophorae.

The diversification of section Schoenoxiphium has been dated back to the Middle to Late Miocene (c. 8-16 mya; Martín-Bravo et al., 2019; Márquez-Corro et al., 2020; Villaverde et al., 2021), with its ancestral area probably located in the Drakensberg range in E South Africa, and several subsequent colonizations out of this area have been inferred, including the Cape region, tropical E Africa and Madagascar (Márquez-Corro et al., 2020). Active speciation processes in the Drakensberg could have taken place in concert with the uplift of this range during the MioPliocene boundary (5.5 mya; Márquez-Corro et al., 2020). The weak morphological boundaries, species lack of monophyly, together with the often overlapping distribution of species within lineages (Villaverde et al., 2017; see maps in Taxonomic treatment) and their frequent turnover along various ecological gradients (elevation, wetness, forest to grassland; see habitat description under each species) suggest that ecological specialization may have played an important role in the diversification of some main lineages within section Schoenoxiphium, perhaps linked to geomorphological evolution in the region (Bentley et al., 2014).

\section{Cytogenetics}

Sedges (Cyperaceae) present several uncommon cytological characteristics among angiosperms: i) degeneration of three nuclei during pollen formation (pseudomonads), ii) postreductional meiosis with separation of chromosomes in anaphase II instead of anaphase I (inverted meiosis), and iii) extended kinetochoric activity during cell division (holocentric/holokinetic chromosomes). These peculiarities allow a more relaxed chromosome number inheritance, as fragments from fission events are very likely to carry functional centromeres, and fused chromosomes would not have division problems due to inverted meiosis (Mola \& Papeschi, 2006; Hipp, Escudero \& Chung, 2013; Márquez-Corro et al., 2019a). Chromosome number evolution in Carex is dominated by dysploid events -even within species-, with exception of the polyploid early-diverging subgenus Siderosticta Waterway and other minor sparse lineages (Roalson, 2008; Hipp, Rothrock \& Roalson, 2009; Escudero et al., 2012). Some species present large dysploid series (Luceño \& Castroviejo, 1991; Hipp et al., 2010). The fact of dealing with extremely variable, wide chromosome number ranges even within species has historically 
149 hindered the estimation of ancestral numbers for the genus (Wahl, 1940; Roalson, 2008), even

150

151

152

153

154

155

156

157

158

159

160

161

162

163

164

165

166

167

168

169

170

171

172

173

174

175

176

177

178

179

180

181

182

183

184

185

186

187

188

with recent evolutionary analyses (Escudero et al., 2014; Márquez-Corro et al., 2019b, 2021).

No cytological study has ever been carried out in Carex section Schoenoxiphium. This lack of karyological knowledge has motivated its study during the last few years. Although some of these chromosome counts have been previously used for evolutionary works at different levels (Luceño et al., 2013; Márquez-Corro et al., 2019b; Márquez-Corro et al., 2021), these chromosome counts are formally published here for the first time.

\section{Inflorescence structure}

The structure of the inflorescence and the terminology of its different parts in Cyperaceae, and particularly in the Cariceae tribe -composed only by genus Carex according to the current concept (Global Carex Group, 2015)- has been the subject of attention since the nineteenth century (Kunth, 1838; Caurel, 1867). However, most works dealing with this topic have been published throughout the twentieth and twenty-first centuries (Snell, 1936; Blaser, 1944; Levyns, 1945; Holttum, 1948; Kukkonen, 1967, 1983, 1984, 1990; Kern, 1974; Eiten, 1976; Smith \& Faulkner, 1976; Goetghebeur, 1986, Reznicek, 1990; Bruhl, 1991; Timonen, 1998; Vegetti, 2002, 2003; Richards, Bruhl \& Wilson, 2006; Guarise \& Vegetti, 2008; Vrijdaghs et al., 2009, 2010; Molina, Acedo \& Llamas, 2012; Reutemann et al., 2012; Gehrke et al., 2012). A summary of the different interpretations may be found in Global Carex Group (2015) and Jiménez-Mejías et al. (2016).

The inflorescence of the species in the section Schoenoxiphium has often been discussed in these studies due to its particularities (Kukkonen, 1983, 1994; Timonen, 1998; Global Carex Group, 2015; Jiménez-Mejías et al., 2016). In short, the inflorescences of the species in the section vary from very simple, reduced to an androgynous spike at the end of the fertile stem, as is the case of C. acocksii and certain morphotypes of C. killickii (Márquez-Corro et al., 2020), to complex, constituting paniculiform inflorescences whose density and branching pattern is variable (Fig. 1). Inflorescences of the species in the section Schoenoxiphium show 1-4 branching orders (Fig. 1). The shape of the last order branches (rachilla) is very typical of the species in the section: straight, flat, linear to lanceolate in outline, with one central vein and ciliated or scabrous at the margins. Complex inflorescences are composed of a variable number of spiciform or paniculiform partial inflorescences (paracladia). Frequently, the lower partial inflorescences are variably pedunculated, usually distant and sometimes nodding, while the upper ones are usually sessile or subsessile and usually appear congested in the upper part of the inflorescence, which makes their individualization quite difficult. Each partial inflorescence is subtended by a leaflike bract (more rarely, glumaceous, setaceous or intermediate between the latter two types) and surrounded at its base by an usually tube-shaped prophyll called tubular cladoprophyll (JiménezMejías et al., 2016). The type of prophyll in the section Schoenoxiphium depends on the order of branching, so that, except in unispicate inflorescences, the cladoprophyll of the first-order branches is tubular (Fig. 1) and usually hyaline, while those of the following branching orders are utriculiform cladoprophylls (Fig. 2A), bisexual or unisexual utricles (Fig. 2B,C) or, more

Peer] reviewing PDF | (2021:02:57694:1:1:NEW 25 Mar 2021) 
189

190

191

192

193

194

195

196

197

198

199

200

201

202

203

204

205

206

207

208

209

210

211

212

213

214

215

216

217

218

219

220

221

222

223

224

225

226

227

228

rarely (C. lancea, C. multispiculata and C. schweickerdtii), open perigynia (Fig. 2D-F). However, the morphology of each type of cladoprophyll is not always homogeneous, so that tubular cladoprophylls may vary from strictly tubular to hypocrateriform, symmetric or asymmetric in the apical opening (mouth); likewise, the utriculiform cladoprophylls also vary notably in shape, although those that resemble bisexual utricles predominate, and are distinguishable from unisexual utricles by their broad and obliquely truncated mouth. It is worth noting the extraordinary morphological variability of prophylls, encompassing all imaginable intermediate forms between unisexual utricles and open perigynia (see Materials and Methods for a detailed explanation of prophyll types and the terminology adopted here; Fig. 2).

To summarize, there is a plethora of useful but fragmentary data that have contributed to improve our knowledge on the systematics, biogeography and evolution of section Schoenoxiphium. Thus, during the last 13 years, the authors of this study have been studying these aspects, which has resulted in several publications specifically focused on this group (Gehrke et al., 2010; Villaverde et al., 2017, 2021; Márquez-Corro et al., 2017, 2020; MárquezCorro et al., 2021). It is particularly noteworthy how the increasing efforts in taxonomic and molecular sampling have enabled a much more robust and sound phylogenetic inference for section Schoenoxiphium. This has been possible thanks to the progressive development of sequencing methods (from a few Sanger-sequenced DNA regions to the massive parallel sequencing of hundreds or thousands of loci with genomic techniques like Hyb-Seq or RADseq). However, a critical taxonomic revision that accounts for this phylogenetic framework is still lacking. Therefore, we herein present a fully updated and integrative global monograph of the group that includes the study of more than 1,000 herbarium specimens and considers all available sources of evidence.

\section{Materials \& Methods}

\section{Morphological study}

We have studied 1,017 vouchers of type and representative material (Table S1 in Supplementary Material) from the following herbaria (codes following Thiers, 2020), through in situ visits, the request of material on loan or digitized images of herbarium specimens, and the study of specimens available in the online repository JSTOR Global Plants (https://plants.jstor.org/): BM, BOL, E, EA, GRA, K, MA, MO, NBG, NU, P, PRE, S, SALA, SBT, TCD, TUB, UBT, UPOS, and Z. Material was also collected in the field during seven fieldwork campaigns to South Africa and Lesotho by some of the authors between 2008 and 2017, and deposited at BOL, PRE, NU and UPOS. Permits to collect were issued by CapeNature (AAA0005-00054-0028 to Abraham Muthama Muasya) and Ezemvelo KZN Wildlife (34/2008 to Abraham Muthama Muasya) and by The Lesotho Ministry of Tourism, Environment and Culture (collecting number permit $\mathrm{MTEC} / \mathrm{NES} / \mathrm{CONV} / 1$ to Tamara Villaverde). Observations from iNaturalist (https://www.inaturalist.org) considered as reliable (i.e. identifiable with confidence) were 
229 identified to the species level; these records also added relevant chorological information. In 230 addition, we performed a thorough nomenclatural revision to clarify the accepted names and 231 their synonyms. We consulted all the pertinent protologues and traced for original material with 232 the help of Stafleu \& Cowan (1976) and herbarium staff, resulting in the finding of type material 233 at E, H, HAL, S, SAM and UPS.

234 Herbarium material was identified and studied taking into account all relevant previous 235 taxonomic literature, and with a special focus on the most important characters for the taxonomy 236 of section Schoenoxiphium (Kükenthal, 1909; Levyns, 1945; Kukkonen, 1983; Gordon-Gray, 237 1995; Márquez-Corro et al., 2017; this study): width and length of rhizome internodes; lower 238 sheath leaves bladeless or with lamina, decaying or not in fibres; width and cross section of the 239 240 leaves; presence-absence of papilles and/or pricklets in leaf margins; ligule length; lowest inflorescence bract sheathing or not; inflorescence structure; length of partial inflorescences peduncles; presence-absence of open perigynia and utriculiform cladoprophylls; shape, size and indumentum of unisexual utricles; relative length of the rachilla with respect to the utricle; shape and size of the achenes; and shape of persistent style base. Macroscopic measurements were performed using a standard ruler. An Olympus SZX16 binocular magnifying glass was used to measure culm-width, leaf-width, ligules, glumes, achenes and utricles. Regarding the terminology used in the key and in the descriptions, we basically follow the guidelines set out by Global Carex Group (2015) and Jiménez-Mejías et al. (2016), with minor modifications. We consider rhizome "slender" when its diameter does not exceed $3 \mathrm{~mm}$, "moderately stout" when the diameter ranges between 3 and $6 \mathrm{~mm}$ and "stout" when exceeding 6 $\mathrm{mm}$ in diameter. We consider that the lowest bract of the inflorescence is not sheathing when the sheath is open or closed up to $7 \mathrm{~mm}$ above the insertion of the bract on the culm. The basal sheaths characters are referred only to those of fertile culms. Features and dimensions of the utricle always refer to mature unisexual utricles; in the same way, the shape and dimensions of the female glumes refer exclusively to those axilating the unisexual utricles, not the bisexual ones or to the utriculiform cladoprophylls. On the contrary, achenes have been described considering those included in utriculiform cladoprophylls, in glumiform perigynia, in glumiform cladoprophylles (see below) and in unisexual and bisexual utricles, since no variation was observed. We have considered partial inflorescence (first order paracladium; Guarise \& Vegetti, 2008) as the branch that arises directly from the main axis and branches at least twice (Fig. 1).

Regarding prophylls, Jiménez-Mejías et al. (2016) consider two types: (i) perigynium as any prophyll enclosing a female flower and surrounding the base of a terminal truncated short branch, and (ii) cladoprophyll as any modified prophyll surrounding lower order branches. When the margins of perigynia are fused, constituting a more or less closed structure, we distinguish two types of perigynia: (i) bisexual utricle (Fig. 2B), which encloses an achene and whose axis projects, outside the cladoprophyll, into a male spikelet; and (ii) unisexual utricle (Fig. 2A), when the axis is vestigial or protrudes from the apex of the cladoprophyll, but does not elongate into new branches that carry flowers nor a male spikelet, at most the branches carry some vestigial scales (glumes) at the apex. In addition, when the margins of cladoprophylls are fused, 
269

270

271

272

273

274

275

276

277

278

279

280

281

282

283

284

285

286

287

288

289

290

291

292

293

294

295

296

297

298

299

300

301

302

303

304

305

306

307

308

Jiménez-Mejías et al. (2016) also accept two types: (i) tubular cladoprophyll (Fig. 1), when it does not enclose a female flower; and (ii) utriculiform cladoprophyll (Fig. 2C), if they contain an achene and the axis of the branch protrudes from the apex of the cladoprophyll, generating new branches that produce female flowers and end in a male spike. Since the species of the section Schoenoxiphium show a great variability in the shape and position of the different types of prophylls, we accept here the classification proposed by Jiménez-Mejías et al. (2016), but we will additionally refer to glumiform perigynia, as those last-order branch prophylls whose edges are not fused or only very shortly in the base (Fig. 2D-E), similar to those of the species of the former genus Kobresia and those observed in C. lancea (Thunb.) Baill., C. multispiculata Luceño \& Martín-Bravo, and C. schweickerdtii (Merxm. \& Podlech) Luceño \& Martín-Bravo, and to glumiform cladoprophylls as the open or shortly fused in the base prophylls that contain an achene and whose branch axis protrudes from the apex of the cladoprophyll, generating new branches that produce female flowers and end in a male spike (Fig. 2F).

The distribution of taxa was specified using TDWG geographical codes at level 3 ("Botanical countries"; Brummitt, 2001), and represented in maps using the program QGis (https//qgis.org). Herbarium specimens without exact coordinates were manually georeferenced when the locality was clear and precise, in order to represent species distributions as complete as possible. Habitats description was based on field observations as well as on the classification of South African vegetation by Mucina \& Rutherford (2006). Analytical drawings were prepared for all accepted species by M. Sánchez-Villegas, except for C. badilloi Luceño \& Márq.-Corro, C. bolusii C.B.Clarke (prepared by R. Tavera) and C. chermezonii Luceño \& Martín-Bravo (only known from the type material), including details of the most important diagnostic characters of inflorescences, utricles and achenes. Representative iconography and selected references relevant for each accepted species were cited. The conservation status of species was reviewed and mainly obtained at the national level for South Africa (Red List of South African Plants; SANBI, 2020) and only for one species at the global level (Carex ludwigii; IUCN, 2020).

\section{Molecular study}

We included new samples in the previous molecular phylogenies of section Schoenoxiphium based on Sanger-sequencing of DNA regions (Villaverde et al., 2017; ten new samples, representing six species, with all four regions each; see Table S2 in Supplementary Material) and RAD-seq (Villaverde et al., 2021; 2 new samples representing two species). Thus, we expanded the taxon sampling, including one herein newly described species previously unsampled $(C$. gordon-grayae Luceño, Márq.-Corro \& Sánchez-Villegas sp. nov.) and one species recently included in the section (C. acocksii; Márquez-Corro et al., 2020). Methods for DNA extraction, PCR amplification and phylogenetic analysis were similar to the ones used in the respective Sanger and RAD-seq studies (Villaverde et al., 2017, 2021, respectively). For the RAD-seq assembly, we used iPyrad v.0.9.59 (Eaton \& Overcast, 2020). Maximum likelihood (ML) trees, using the concatenated individual marker matrices and the concatenated RAD-seq matrix, independently, were inferred in RAxML 7.2.6 (Stamatakis, 2014) and bootstrap support for 
309 clades were calculated using 200 non-parametric replicates searches from random starting trees

310 using an unpartitioned GTR+CAT nucleotide substitution model.

311

\section{Cytogenetic study}

313 Cytogenetic preparations were performed through the fixation of developing pollen grains from

314 immature anthers, following the standard protocol for Carex described in Luceño (1988) and

315 Escudero et al. (2008). Diploid numbers were inferred from obtained meiotic plates in Diakinesis

316 (DK), Metaphase I (MI) or Metaphase II (MII) of the meiosis, as well as in Pollen Grain Mitosis

317 (PGM), more rarely in premeiotic mitosis.

318

319

320

\section{Nomenclature}

The electronic version of this article in Portable Document Format (PDF) will represent a

321

published work according to the International Code of Nomenclature for algae, fungi, and plants

322 (ICN), and hence the new names contained in the electronic version are effectively published under that Code from the electronic edition alone. In addition, new names contained in this work which have been issued with identifiers by IPNI will eventually be made available to the Global Names Index. The IPNI LSIDs can be resolved and the associated information viewed through any standard web browser by appending the LSID contained in this publication to the prefix "http://ipni.org/". The online version of this work is archived and available from the following digital repositories: PeerJ, PubMed Central, and CLOCKSS.

329

330

331

\section{Results}

332

\section{Taxonomic revision}

333

334

Our taxonomic treatment considers 21 accepted species, one of them newly described here $(C$. gordon-grayii sp. nov.). Detailed morphological descriptions, distribution maps and analytical drawings are provided for all of them, as well as a general description for section Schoenoxiphium. An identification key is provided to distinguish between all species. A total of 19 new formal typifications and one nomen novum are provided. Our exhaustive revision of materials also revealed that section Schoenoxiphium is distributed in 13 countries through southern and eastern Africa, with an interesting disjunction in West Africa (C. dregeana in W of Angola) and a population of $C$. spartea in the Republic of Yemen (Arabian Peninsula, Asia; AlKhulaidi, 2013), whose voucher we have not been able to confirm, although we consider its presence plausible. South Africa has the highest number of species (20 out of 21), followed by Lesotho (11). Within South Africa, the provinces with the greatest species richness are the Eastern Cape with 17 species and KwaZulu-Natal with 15 (Fig. 3).

347 Carex section Schoenoxiphium consists of five evolutionary lineages (Fig. 4): (A) C.

348 schweickerdtii, C. lancea and C. multispiculata; (B) C. burkei, C. basutorum, C. distincta, and C. 
349

350

351

352

353

354

355

356

357

358

359

360

361

362

363

364

365

366

367

368

369

370

371

372

373

374

375

376

377

378

379

380

381

382

383

384

385

386

387

388

killickii; (C) C. capensis and C. sciocapensis; (D) C. acocksii, C. perdensa, C. dregeana, C. esenbeckiana, and C. spartea; (E) C. pseudorufa, C. ludwigii, C. kukkoneniana, C. badilloi and C. bolusii. The herein described species $C$. gordon-grayii appears in an unresolved lineage.

The monophyly of Carex section Schoenoxiphium is strongly supported using both Sanger and RAD-seq datasets (97\% and 100\% BS, respectively; Fig. 4 and Figs. S1-S2). Most of the main lineages are strongly supported in both phylogenetic reconstructions, with the exception of Clade A. The relationships between all these clades are weakly supported in the phylogenetic reconstruction using four different DNA regions (Fig. 4A), but they are strongly supported using the genomic RAD-seq dataset (Fig. 4B). Carex ackocsii appears in a weakly supported lineage sister to Clade D, while C. gordon-grayii in an unresolved lineage (Fig. 4A). Carex sciocapensis is retrieved as paraphyletic (Fig. 4A,B). Summary statistics for the individual marker matrices obtained with AMAS (Borowiec, 2016) are found in Table S3. Summary statistics for the RAD assembly are found in Table S4 in Supplementary Material.

\section{Chromosome numbers and meiotic configurations}

We report new chromosome numbers for 15 species (two thirds of the section) and one putative (morphologically intermediate) hybrid Table 2, Figs. 4 and 5). The counts show a distribution around three chromosome number clusters (see also Márquez-Corro et al., 2021): $2 \mathrm{n}=24-36$, $2 \mathrm{n}=60-72$ and a single count of $2 \mathrm{n}=88$ (Fig. 5). We also indicate the meiotic configuration, which may be different for the same chromosome number, due to the presence of univalents, bivalents or trivalents.

Specifically, in Clade A, C. schweickerdtii displayed 30II in MI (inferred diploid 2n =60; Fig. 5A); C. lancea showed $44^{\mathrm{II}}$ in MI (inferred diploid $2 \mathrm{n}=88$; Fig. $5 \mathrm{~B}$ ) and C. multispiculata showed $31^{\mathrm{II}}$ in MI (inferred diploid $2 \mathrm{n}=62$; Fig. $5 \mathrm{C}$ ), $1^{\mathrm{III}}+29^{\mathrm{II}}+1^{\mathrm{I}}$ (inferred diploid $2 \mathrm{n}=62$; Fig. $5 \mathrm{C}$ ) and $2 \mathrm{n}=$ ca. 62 in premeiotic mitosis. In Clade B, C. burkei showed $33^{\text {II }}$ in MI (inferred diploid 2n =66; Fig. 5D), 35 ${ }^{\mathrm{II}}$ in MI (inferred diploid $2 \mathrm{n}=70$; Fig. 5E) and $36^{\mathrm{II}}$ in MI (inferred diploid $2 \mathrm{n}=72$; Fig. $5 \mathrm{~F}$ ) and $C$. killickii displayed $1^{\mathrm{II}}+34^{\mathrm{II}}$ in $\mathrm{MI}$ (inferred diploid $2 \mathrm{n}=71$; Fig. $5 \mathrm{G}$ ), $36^{\mathrm{II}}$ in $\mathrm{MI}$ (inferred diploid $2 \mathrm{n}=72$; Fig. $5 \mathrm{H}$ ) and $\mathrm{n}=36$ in pollen grain mitosis (inferred diploid $2 \mathrm{n}=72$ ). In Clade $\mathrm{C}$, C. capensis showed $\mathrm{n}=36$ in pollen grain mitosis (inferred diploid $2 \mathrm{n}=72$; Fig. 5I) and C. sciocapensis displayed $\mathrm{n}=34$ in pollen grain mitosis (inferred diploid $2 \mathrm{n}$ $=68$; Fig. $5 \mathrm{~J})$. In Clade D, C. perdensa showed $15^{\mathrm{II}}$ in MI $(2 \mathrm{n}=30$; Fig. $5 \mathrm{O})$ and $\mathrm{n}=15$ in pollen grain mitosis (inferred diploid $2 \mathrm{n}=30$ ); $C$. dregeana showed $16^{\mathrm{II}}$ in $\mathrm{MI}$ (inferred diploid $2 \mathrm{n}=$ 32; Fig. 5P), $n=17$ in pollen grain mitosis (inferred diploid $2 n=34$; Fig 5Q); C. esenbeckiana displayed $13^{\mathrm{II}}$ in MI (inferred diploid $2 \mathrm{n}=26$; Fig. 5R) and C. spartea displayed $\mathrm{n}=12$ in pollen grain mitosis (inferred diploid $2 n=24$; Fig. $5 \mathrm{~S}$ ) and $\mathrm{n}=13$ in pollen grain mitosis (inferred diploid $2 \mathrm{n}=26$; Fig. 5T). The hybrid C. dregeana $\times$ C. spartea showed $\mathrm{n}=13,14$ in pollen grain mitosis (inferred diploid $2 \mathrm{n}=27$ ), $\mathrm{n}=12,13,14$ in pollen grain mitosis (inferred diploid $2 \mathrm{n}=26$; Fig. 5U) and $\mathrm{n}=14,15,16$ in Pollen Grain Mitosis (inferred diploid 2n $=30$; Fig. 5V). 
389 Finally, in Clade E, C. pseudorufa showed 32II in MI (inferred diploid 2n =64; Fig. 5K); .

390 bolusii showed $18^{\mathrm{II}}$ in DK $(2 \mathrm{n}=36$; Fig. $5 \mathrm{~L})$ and $\mathrm{n}=18$ in pollen grain mitosis (inferred diploid

$3912 \mathrm{n}=36$ ); C. badilloi showed $\mathrm{n}=17$ in (inferred diploid $2 \mathrm{n}=34$; Fig. $5 \mathrm{M}$ ) and $\mathrm{n}=18$ (inferred

392 diploid $2 \mathrm{n}=36$; Fig. $5 \mathrm{M}$ ) in pollen grain mitosis and C. ludwigii displayed $17^{\mathrm{II}}$ in MI (inferred

393 diploid $2 \mathrm{n}=34$ ) and $\mathrm{n}=17$ in pollen grain mitosis (inferred diploid $2 \mathrm{n}=34$; Fig. $5 \mathrm{~N}$ ).

394

395

396

397

398

399

400

401

402

403

404

405

406

407

408

409

410

411

412

413

414

415

416

417

418

419

420

421

422

423

424

425

426

427

428

\section{Discussion}

We have produced a fully updated and integrative study of Carex section Schoenoxiphium based on 1,017 herbarium specimens, field works conducted between 2008-2017, 164 sequenced samples represented in a Sanger and a RAD-seq phylogeny, cytogenetic counts on 44 populations, a nomenclatural survey and an exhaustive review of previous taxonomic and phylogenetic works.

Our taxonomic treatment considers 21 accepted species (Table 3), one of them newly described here (C. gordon-grayii sp. nov.). We provide detailed morphological descriptions, distribution maps, analytical drawings and an identification key including all species, as well as a general description for section Schoenoxiphium. A total of 19 new formal typifications and one nomen novum are provided.

\section{Systematics of Schoenoxiphium}

Carex section Schoenoxiphium consists of five well-supported evolutionary lineages: (A) C. schweickerdtii, C. lancea and C. multispiculata; (B) C. burkei, C. basutorum, C. distincta and C. killickii; (C) C. capensis and C. sciocapensis; (D) C. acocksii, C. perdensa, C. dregeana, C. esenbeckiana and C. spartea; (E) C. pseudorufa, C. ludwigii, C. kukkoneniana, C. badilloi and C. bolusii. Although Clade A is retrieved in a weakly supported lineage (Fig. 4), it has been shown to be strongly supported in Márquez-Corro et al. (2020). Similar situation occurs with $C$. acocksii, which is found in a strongly supported lineage in Márquez-Corro et al. (2020) but not here. Carex gordon-grayae sp. nov. and C. chermezonii (the later not included in any molecular analysis to date) are the only two species whose phylogenetic relationships have not been resolved yet. However, their morphological characteristics led us to hypothesize that $C$. chermezonii would belong to Clade A, and C. gordon-grayae to an isolated lineage.

Section Schoenoxiphium probably originated in the Mid-Miocene in the Afrotropical region and diversified in-situ (mean c. 8-16 mya; Martín-Bravo et al., 2019; Márquez-Corro et al., 2020; Villaverde et al., 2021), probably in the Drakensberg and adjacent mountain ranges (MárquezCorro et al., 2020). Most of the species in Schoenoxiphium are suspected to have originated during the Late Miocene (Villaverde et al., 2021), which corresponds to the uplift of the Drakensberg Mountains, the only South Africa's alpine zones. The provinces of Eastern Cape and KwaZulu-Natal treasure the highest number of section Schoenoxiphium species in South Africa (17 and 15, respectively; Fig. 3) followed by the country of Lesotho (11 species). 
429 (A) C. schweickerdtii, C. lancea, C. multispiculata, (C. chermezonii?).

430

431

432

433

434

435

436

437

438

439

440

441

442

443

444

445

446

447

448

449

450

451

452

453

454

455

456

457

458

459

460

461

462

463

464

465

466

467
This small clade of three species (or perhaps four; our untested hypothesis is that $C$. chermezonii belongs to this clade) is formed by large plants with wide leaves and straight apex leaves (but usually somewhat curved in C. lancea). Unlike other species in the section, these species may have open perigynia (occasional in C. multispiculata; not seen in C. chermezonii). Utricles are smooth, linear and gradually attenuated into a smooth beak; usually of medium size (4.4-6.5 $\mathrm{mm})$, but C. schweickerdtii may display among the largest utricles in the section $(6-10 \mathrm{~mm})$. Species in this clade are mainly distributed in southern Africa; additionally, C. schweickerdtii is also found in Zimbabwe, C. multispiculata in Madagascar, and C. chermezonii has only been found in its type locality in the Tsaratanana mountains of Madagascar. They usually occur in edges of streams or damp places in medium-high mountains (C. schweickerdtii also in stony meadows), although $C$. lancea is found in forests at low elevations (20-1500 m).

(B) C. burkei, C. distincta, C. basutorum, C. killickii.

Species in this clade are characterized by plants of small height, with very narrow or filiform leaves $(0.2-3.7 \mathrm{~mm}$, but $C$. burkei has wider ones, $1.5-5.5 \mathrm{~mm}$ ) curved to curled at the tip. Utricles are linear or narrowly ellipsoid, more or less hispid in the upper half, and smaller than 5 $\mathrm{mm}$, with the exception of $C$. basutorum $(5-7.2 \mathrm{~mm})$ and some forms of $C$. killickii. This clade of four species is endemic to Lesotho and South Africa and they occur at medium-high elevations (1400-3150 m; but $C$. killickii has been exceptionally found at $550 \mathrm{~m}$ ). They are typically found in open and dry grasslands, although $C$. killickii also occur in mesophilous meadows and $C$. burkei in temporary flooded meadows and edges of streams.

\section{(C) C. capensis, C. sciocapensis}

Carex capensis and C. sciocapensis have basal sheaths that are bladeless and the lowest bract of the inflorescence is not sheathing. The remaining species of the section have basal sheaths with lamina (except sometimes only the lowest with lamina), and a sheathing lowest bract in the inflorescence (except C. basutorum, C. chermezonii and multispiculata). C. capensis and $C$. sciocapensis are two species endemic to the southernmost areas of the Cape Region (South Africa). Both species occur at low elevations $(5-750 \mathrm{~m})$ and $C$. sciocapensis can also be found at medium elevations (below $1500 \mathrm{~m}$ ). Carex capensis inhabit open and sunny places whereas $C$. sciocapensis is common in shady places and margins and clearing of forest (and sometimes in fynbos areas).

(D) C. acocksii, C. perdensa, C. dregeana, C. spartea, C. esenbeckiana

Peer) reviewing PDF | (2021:02:57694:1:1:NEW 25 Mar 2021) 
468 The clade grouping C. acocksii, C. perdensa, C. dregeana, C. spartea and C. esenbeckiana is 469 characterized by fibrous basal sheaths (although in $C$. perdensa are entire or scarcely fibrous) 470 and by smooth utricles up to $5.5 \mathrm{~mm}$ (rarely $6 \mathrm{~mm}$ in C. esenbeckiana). This clade of five species 471 has the broadest distribution. Carex dregeana, C. spartea and C. esenbeckiana are distributed 472 across S and E Africa (C. dregeana also disjunctly in Angola and Madagascar) from low to high 473 elevations (4-2850 m). Carex spartea is the species with the northernmost distribution in the 474 section, reaching SE Arabian Peninsula. In contrast with these widely distributed species, $C$. 475 acocksii and C. perdensa are restricted endemics in South Africa, where they are found at 476 medium-high elevations (1200-1950 m). All of these species occur in open places, except $C$. 477 esenbeckiana, which is found in shady places in afromontane forests.

478

479 480

\section{(E) C. pseudorufa, C. ludwigii, C. kukkoneniana, C. badilloi and C. bolusii}

The clade grouping C. pseudorufa, C. ludwigii, C. kukkoneniana, C. badilloi and C. bolusii is characterized by basal sheaths entire to slightly fibrous and by scabrid utricles towards the apex. These species are mainly distributed in South Africa and Lesotho, while C. kukkoneniana reaches further north to Tanzania. They are found in edges of streams and other wet places at medium-high elevations, although $C$. badilloi and C. bolusii can also be found in grasslands and open places.

\section{Carex gordon-grayae}

C. gordon-grayae, long confused with C. esenbeckiana (Clade D), shows a number of distinctive morphological characters that do not match any of the groups described so far: (i) basal sheaths not or scarcely fibrous, typical of all groups except the Clade D; (ii) broad leaves (up to $9 \mathrm{~mm}$ ), as in Clade A species; (iii) subsessile or shortly pedunculated partial inflorescences, which is common in the Clades B, C and D; iv) lowest bract sheathing, unlike Clade C; v) hyaline glumes and pyramidal style base, as in C. acocksii; and (vi) long (5.4-7.9 mm), utricles narrowly linear and gradually attenuated in a long beak, unlike the D and E Clades. Moreover, this species is a rare endemic to SE of KwaZulu-Natal and E of Eastern Cape, where it inhabits forest near the coast, unlike the remaining species of the section, except $C$. esenbeckiana and C. sciocapensis.

\section{Cytogenetics}

Chromosome number evolution in Carex is dominated by dysploid events (Roalson, 2008; Hipp et al., 2009; Escudero et al., 2012) with some species presenting large dysploid series (Luceño \& Castroviejo, 1991; Hipp et al., 2010). The section Schoenoxiphium does not seem an exception to this general pattern in genus Carex, and it displays a wide range of chromosome numbers, from $2 n=24$ to $2 n=88$ (C. spartea and C. lancea, respectively; Table 2, Figs. 4 and 5). However, the distribution of the counts is rather discontinuous either overall and within some of the clades. High numbers have been reported for the Clade A $(2 n=60,62$ and 88$)$, Clade B $(2 n=66,70-$ 
508 72), Clade C $(2 n=68,72)$ and part of the Clade $E(2 n=64)$. The consistent presence of

509

510

511

512

513

514

515

516

517

518

519

520

521

522

523

524

525

526

527

528

529

530

531

532

533

534

535

536

537

538

539

540

541

542

543

544

545

546

547

relatively high chromosome numbers in all these clades suggests a likely high ancestral number for the section. The most diverse and karyologically complex would be Clade $\mathrm{D}$, in which the chromosome counts are reduced to half $(2 \mathrm{n}=24,26,27,30,32,34)$ and in Clade $\mathrm{E}(2 \mathrm{n}=34,36)$ excluding C. pseudorufa $(2 \mathrm{n}=64)$. This conspicuous reduction of chromosome numbers is probably due to a massive series of fusion events that have occurred through the diversification of the lineage, rather than several polyploid events in the Clades A, B, C and E. In fact, fusion events have been inferred to happen ca. 1.5 times as fission events in the non-Siderostictae Carex (Supplementary Data 7 in Márquez-Corro et al., 2019b). Moreover, a preliminary study that is currently being carried out considering genome size variation among and within species of the section points to the fusion hypothesis, because genome sizes do not vary proportionally to chromosome number (Márquez-Corro et al., 2021). However, the detection of an unusual high number within one of the two reduced lineages (i.e., C. pseudorufa) is very intriguing. Genome size of this species is yet unknown, so there are two possible hypotheses: either a rare polyploid event in C. pseudorufa or, at least, two convergent, independent fusion events in the reduced lineages (based on the topology retrieved in the RAD-seq phylogeny, see Fig. 4). Chromosome number variation of the section is very promising and posits possible evolutionary scenarios in which the establishment in different niches with sympatric species could be through karyotyperelated adaptation, since most members of the section inhabit the Drakensberg area (including most of the Eastern Cape mountains).

\section{Taxonomic treatment}

CAREX sect. SCHOENOXIPHIUM (Nees) Baillon, Hist. pl., monogr. Cypér.: 345, 1894 [1893]

इSchoenoxiphium Nees in Linnaea 7: 531, 1832 [basionym]

Type: Schoenoxiphium capense Nees (=Schoenus lanceus Thunb.)

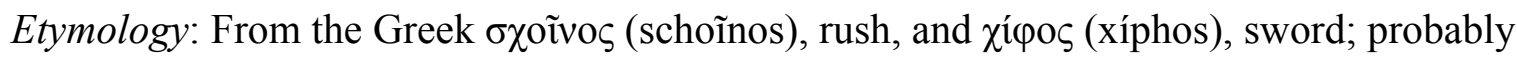
because of the shape and sharp edges of the leaves of some of its species.

Perennial herbs, not caespitose to densely caespitose. Rhizome with short to long internodes, brown. Flowering culms $(4.5) 10-180(200) \mathrm{cm}$, erect or, more rarely, nodding, acutely to obtusely trigonous, smooth to scabrid, $0.4-4 \mathrm{~mm}$ wide at the middle. Leaves $(0.2) 0.4-15(18) \mathrm{mm}$ wide, shorter to longer than the inflorescence, soft to coriaceous, filiform to linear, flat, involute, canaliculate, carinate or plicate, usually scabrid at the margin and distal part of abaxial midrib,

Peer) reviewing PDF | (2021:02:57694:1:1:NEW 25 Mar 2021) 
548 with straight to curled apex; ligule (0.1)0.3-12(17) $\mathrm{mm}$ long. Basal sheaths entire to very fibrous, 549 usually with lamina, but sometimes lowermost bladeless. Lowest bract of the inflorescence leaf-

550 like, more rarely glumaceous or setaceous, shorter to longer than the inflorescence, not sheathing 551 or with a sheath up to $84 \mathrm{~cm}$ long. Inflorescence branching 1-4 times, reduced to a single,

552 terminal spike or, more frequently, composed by several panicles and/or spikes, one terminal and 553 the remaining lateral (partial inflorescences) sessile to longly pedunculate, overlapping to distant, 554 erect to nodding. Glumiform perigynia and glumiform cladoprophylls rarely present. Tubular 555 cladoprophylls always present except in C. acocksii and unispikate morphotypes of C. killickii). 556 Uriculiform cladoprophylls frequently present. Male glumes usually ovate to lanceolate, more 557 rarely oblong, obovate or elliptic, brown to yellowish-brown, with a green central band, ending 558 in an aculeate mucro or ariste, more rarely acuminate, acute or obtuse. Female glumes usually 559 ovate, more rarely elliptic, lanceolate, obovate, oblong or suborbicular, brown, reddish-brown or

560

561

562

563

564

565

566

567

568

569

570

571

572

573

574

575

576

577

578

579

580

581

582

583

584

585

586

587

yellowish-brown, with a green central band, ending in an aculeate mucro or ariste, more rarely acuminate, acute or obtuse. Unisexual utricles present or, sporadically, absent, linear, lanceolate, oblong, ovate or elliptic in outline, straight or, more rarely, curvate or arcuate, straw-coloured, yellowish-brown or brown when mature, smooth to densely aculeate, especially in the upper tiers, with numerous, very prominent veins across the entire surface, rarely faintly veined, suberect to patent, gradually attenuate or abruptly contracted into an smooth to aculeate, bidentate, slightly bifid, split, truncate or irregular beak; rachilla usually reaching the apex or protruding from it, more rarely rudimentary to reaching the half of the utricle length. Bisexual utricles wide and obliquely truncate at the apex, rarely absent. Achenes ovate-trigonous or, more frequently ellipsoid-trigonous to oblong-trigonous, straw-coloured, yellowish-brown to darkbrown when mature, tipped by an obtusely trigonous to subterete, neck-like or, more rarely, pyramidal, persistent style base.

\section{Notes}

In addition to the names (accepted and synonyms) contained in the present monograph, the following names have been included under Schoenoxiphium, although they are now considered as synonymous of accepted names included in other sections of the genus Carex (Global Carex Group, 2015; Roalson et al., 2020; Villaverde et al., 2020):

Schoenoxiphium clarkeanum Kük. (accepted name Carex bonatiana (Kük.) Ivanova, former Kobresia bonatiana Kük.).

Schoenoxiphium fragile (C.B. Clarke) C.B. Clarke (accepted name C. bonatiana (Kük.) Ivanova).

Schoenoxiphium hissaricum Pissjauk. (accepted name Carex pseudolaxa (C.B. Clarke) O. Yano, former Kobresia pseudolaxa Pissauk.). 
588 Schoenoxiphium kobresioideum Kuk. (accepted name Carex kobresioidea (Kük.) S.R. Zhang, 589 former Kobresia kobresioidea (Kük.) J. Kern).

590

591 Schoenoxiphium kuekenthalianum (Hand.-Mazz.) Ivanova N.A. (accepted name Carex

592 liangshenensis S.R.Zhang, former Kobresia kuekenthaliana).

593

594 Schoenoxiphium laxum (Nees) Ivanova (accepted name Carex pseudolaxa (C.B. Clarke) O.

595 Yano, former Kobresia pseudolaxa Pissauk.)

596

597

598

599

\section{KEY}

600

601

1. Utricles papyraceous, not or very faintly veined, broadly ellipsoid; female glumes mostly

602 scarious, much wider than the utricles and concealing them; inflorescence reduced to a dense,

603 androgynous spike

C. acocksii

604 - Utricles not papyraceous, prominently veined, linear, lanceolate, ovate, oblong or

605 elliptical in outline; female glumes colored, more rarely hyaline, usually narrower than the

606 utricles, never concealing them; inflorescence paniculiform, rarely reduced to a solitary, lax,

607 androgynous spike, but then utricles narrowly linear or female glumes brown, narrower than

608 utricles

609

610

2. Rachilla rudimentary or reaching up to $1 / 2(2 / 3)$ of the length of the utricle C. dregeana

611 - Rachilla well developed, reaching the apex of the utricle or protruding from it ........... 3

612

613 3. Inflorescence very dense, rarely somewhat lax, multispiculate, broadly ovoid to

614 suborbicular, occupying up to the upper $1 / 5$ of the of the culm, rarely up to $1 / 3$, but then composed

615 by $2-3$ suberect to erect, ovoid to suborbicular parts, one terminal and 1-2 lateral, long616 pedunculate, distant parts C. multispiculata

617 - Inflorescence not as above 4

618

619

4. Leaves plicate when fresh, light green; young inflorescence compressed and

620 partially concealed by two lower, distichous bracts; utricles narrowly linear in

621 outline

C. schweickerdtii

622 - Leaves not plicate when fresh, if so (some individuals of C. esenbeckiana), then glaucous

623 and utricles widely ovoid to ellipsoid; young inflorescence never compressed nor concealed by

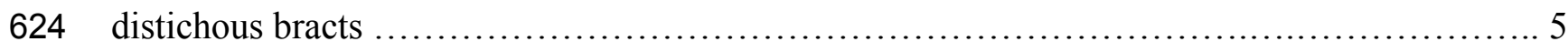

625

626 5. Partial inflorescences nodding (except the uppermost); unisexual utricles (5.3)5.5-8(8.4)

$627 \mathrm{~mm}$ long; linear, narrowly lanceolate or narrowly elliptic .... 6 
628 - $\quad$ Partial inflorescences never nodding (except rarely the lower one), if so (C. ludwigii),

629

630

631

632

633

634

635

636

637

638

639

640

641

642

643

644

645

646

647

648

649

650

651

652

653

654

655

656

657

658

659

660

661

662

663

664

665

666

667

then unisexual utricles (2.6)2.8-3.7(4.9) mm long, broadly ellipsoid 7

6. Partial inflorescences very dense, more or less ovoid, with peduncles much longer than the fertile part

C. pseudorufa

- $\quad$ Partial inflorescences more or less lax, linear to oblong, with peduncles usually shorter than the fertile part

C. lancea

7. Utricles linear, lanceolate, narrowly fusiform or oblong, gradually attenuate into the beak

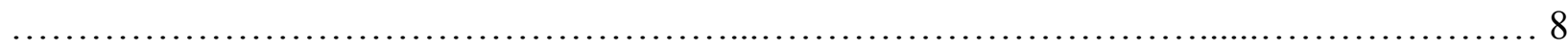

- Utricles broadly ovate or widely elliptic, abruptly contracted, very rarely attenuate (occasionally in C. spartea), into the beak 16

8. Leaves canaliculate, rarely flat, up to $1.5(3.2) \mathrm{mm}$ wide ................................ 9

- $\quad$ Leaves flat or slightly carinate, (2)2.5-9(10) mm wide 11

9. Utricles (5)6-7.2 mm long, densely hispid, at least in the upper half, more or less suberect at maturity: rachilla protruding $(0.5) 1-1.5 \mathrm{~mm}$ from the apex of the utricle

C. basutorum

- $\quad$ Utricles up to $4.1 \mathrm{~mm}$ long, if longer, then glabrous or sparsely aculeate at the apex and patent to erect-patent at maturity; rachilla protruding up to $(0.3) 0.5 \mathrm{~mm}$ from the apex of the utricle 10

10. Utricles and utriculiform cladoprophylls erect to suberect, narrowly ellipsoid; leaf apex strongly curved to curled; female glumes usually dark reddish-brown.

C. distincta

- Utricles and utriculiform prophylls patent, erect-patent or somewhat reflexed, linear to lanceolate in outline, leaf apex straight to little curved, exceptionally somewhat curled; female glumes pale to dark brown

C. killickii

11. Leaves coriaceous, very scabrid and rough on the margins, with the apex usually and clearly curled; lowest bract sheathing, utricles up to 4.2(5) $\mathrm{mm}$ long

C. burkei

- Leaves not or scarcely coriaceous, not or slightly scabrid, with the apex straight, curved or, more rarely, curled; lowest bract sheathing or not; utricles (3.8)4.3-8(10.1) mm long

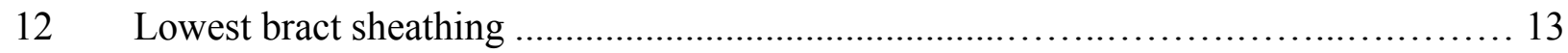

- Lowest bract not sheathing ....................................................... 14

13. Lowermost partial inflorescences long pedunculate, dense; female glumes yellowishbrown to brown

C. kukkoneniana 
668 - Partial inflorescences subsessile to very shortly pedunculate, lax; female glumes hyaline

670

67114 Basal sheaths usually with lamina; lowest partial inflorescences pedunculate; utricles 672 usually arcuate C. chermezonii

673 - $\quad$ Basal sheaths bladeless; partial inflorescences sessile; utricles usually straight ........... 15

674

67515 Densely caespitose (rhizome with short internodes); flowering culms (7.5)10-30(40) cm 676 long; inflorescence ovoid or shortly oblong, dense; utricles (3.8)4.3-5(5.8) mm long, suberect in 677 fruit C. capensis

678 - Not or loosely caespitose (rhizome with more or less long internodes); flowering culms 679 (25)40-70(96) cm long; inflorescence usually long oblong, lax at the maturity; utricles (6.1)6.4680

681

682 16. Leaves narrowly canaliculate or involute, up to $0.7(1.5) \mathrm{mm}$ wide; partial inflorescences very lax, with up to (2)3 female flowers

C. perdensa

684 - Leaves flat or scarcely carinate, more than (1)1.5 mm wide, if narrower, then leaves flat

685 in cross section; at least some partial inflorescence with more than (5) 8 female flowers 17

686

687

688

17. Utricles usually curved, rarely straight; lowermost partial inflorescence nodding; rhizome 689 stout C. ludwigii

690

691

692

693

694 - $\quad$ Utricles straight, exceptionally some of them slightly curved; lowermost partial inflorescence never nodding; rhizome slender to moderately stout 18

18. Utricles (4.3)4.5-5.5(6) mm long, ending in a beak (0.7)1.1-2.2(2.3) mm long, if smaller, then plants distinctly glaucous, lowermost partial inflorescence arising from close to the culm base, and plants growing in shady places

695

696

697 - $\quad$ Utricles (2.6)2.8-4(4.9) mm long, ending in a beak (0.2)0.5-0.8(1) mm long, plants light green to scarcely glaucous, lowermost partial inflorescence arising above of the upper $1 / 2(1 / 3)$ of

698

699 the culm, and plants growing in sunny places

700

701

702

703

19. Densely caespitose; basal sheaths usually very fibrous; culms (1)1.1-1.5(1.9) mm wide at the middle part; lowermost partial inflorescence located usually close to the base of the culm; peduncles of the partial inflorescences included in the sheaths or slightly protruding from it; bisexual utricles rarely present; unisexual utricles with a smooth beak; style base distinctly neck-

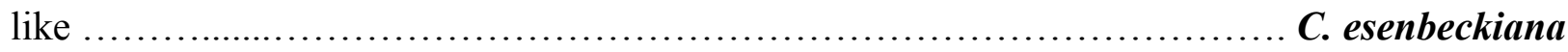

704 - Loosely caespitose; basal sheaths entire to somewhat fibrous; culms $1.7-2 \mathrm{~mm}$ wide at 705 the middle part; lowermost partial inflorescence located above the $1 / 2(2 / 3)$ of the length of the 706 culms; peduncles of the partial inflorescences much protruding from the sheaths; bisexual 
707

708

709

710

711

712

713

714

715

716

717

718

719

720

721

722

723

724

725

726

727

728

729

730

731

732

733

734

735

736

737

738

739

740

741

742

743

744

745

utricles usually present; unisexual utricles with an aculeate beak; style base never neck-like C. badilloi

20. Basal sheaths entire, somewhat broken or slightly fibrous; utriculiform cladoprophylls usually present; most unisexual utricles more or less densely hispid at least in the beak

C. bolusii

Basal sheaths usually very fibrous; utriculiform cladoprophylls rarely present; unisexual utricles smooth, very rarely with a few, very disperse, minute prickles C. spartea

Carex acocksii C. Archer, S. African J. Bot. 63: 342, 1998 [1997].

Type. South Africa. Northern Cape, Calvinia district, in vicinity of FM tower on top of Hantamsberg, Van Rhynshoek farm, 1580 m, 03-X-1987, Reid 1337 (holotype: PRE-0762273-0 digital image!; iso-: BM-000611185 digital image!, GENT-0000090034770 digital image!, K001044967 digital image!, MO-193695 digital image!, NBG-0200446-0 digital image!, P00199375 digital image!, S-06-20520 digital image!, S-G-10688 digital image!, TCD-0000356 digital image!).

Rhizome loosely cespitose, slender, brown. Flowering culms 14-40(47) cm long, bulbiform at the base, erect, terete and prominently ribbed, smooth, leafy only at the base, not reaching the third of the length, 0.6-1.2(1.3) mm wide at the middle. Leaves (0.2)0.6-1.1(1.4) mm wide, much shorter than the inflorescence, moderately rigid, light green or somewhat glaucous, canaliculate or, more frequently, involute in cross-section, scabrous along the margins in all its length; abaxial and adaxial surfaces smooth; ligule 0.8-1.5(2) $\mathrm{mm}$ long. Basal sheaths somewhat fibrous, bladeless. Lowest bract of the inflorescence glumaceous or setaceous with glumaceous base, shorter or longer than the inflorescence length, axilating an utricle, not sheathing. Inflorescence reduced to a solitary, androgynous spike (10)15-24(27) × (3)4-6 mm, with the male part usually shorter, rarely equaling the female one. Glumiform perigynia and glumiform cladoprophylls absent. Tubular cladoprophylls absent. Utriculiform cladoprophylls absent. Male glumes (2.3)2.7-4.5(6) × (1.1)1.8-2.7(3) mm, ovate, obovate or elliptical, brown in the upper half and straw-coloured to hyaline in the lower one, acute to acuminate, exceptionally obtuse. Female glumes (4)4.8-6.2(6.7) × (2.1)2.6-4.3(5.2) mm, longer and much wider than utricles, hiding them, widely obovate to suborbicular, single mid-veined, pale to golden-brown with hyaline margins at the upper parts and hyaline to yellowish at the lower ones, usually ending in a mucro up to 2(2.8) $\mathrm{mm}$ long, very rarely obtuse to roundate at the apex. Utricles 3.4-4(4.6) $\times$ (1.4)1.5-1.9(2.2) mm, unisexual, widely ellipsoid, stipitate, straight, papyraceous, hyaline to pale or golden-brown, translucid, glabrous, smooth, with only a few veins or inconspicuous, suberect and erostrate; rachilla reaching up to the half of the utricle. Achenes 3.2-3.9 $\times 1.4-2 \mathrm{~mm}$,

Peer) reviewing PDF | (2021:02:57694:1:1:NEW 25 Mar 2021) 
746 elliptic, yellowish to dark brown when mature, tipped by a widely pyramidal (mitrate), persistent

747 style base.

748

749

750 Endemic to the Northern Cape province in South Africa [27 CPP]. Fig. 6A.

751

752 Habitat

753 Open grounds and under shrub on dolerite outcrops in Succulent Karoo Biome (Western

754 Mountain Karoo: Hantam Karoo and Roggeveld Karoo); 1450-1600 m.

755

756

757

Etymology

758

759

760

761

762

763

764

765

Named after John Phillip Harison Acocks (1911-1979), a South African botanist and collector.

\section{Iconography}

Figs. 7 and 8A; Archer \& Balkwill (1997, holotype image); Márquez-Corro et al. (2020, detailed photographs of herbarium specimens).

766

767

768

769

770

771

\section{Notes}

773 This species was formerly included in section Petraea Lang. (Archer \& Balkwill, 1997), since it 774 shows unispikate inflorescences, very wide female glumes and hyaline-papyraceous utricles.

775 However, recent molecular studies (Márquez-Corro et al., 2020) have concluded that it should be

776

777

778

779

780

781

782

783

784 785 (VU). However, a recent reevaluation of the conservation status at global level following criteria, categories and guidelines from IUCN $(2012,2017)$ has resulted in the category Critically Endangered (CR) (Márquez-Corro et al., 2020; Márquez-Corro \& Martín-Bravo, 2020). The species is only known from two locations and appears to be severely threatened by overgrazing pressure by livestock and the possible impacts of climate change. included in section Schoenoxiphium, despite its deviant morphological features with respect to the remaining species in the section; nevertheless, its rachilla (flattened and ciliate at the margin) is quite typical of the species of this section (Global Carex Group, 2015; Márquez-Corro et al., 2020). Its position as sister group of the C. spartea clade is not strongly supported (Fig. 4;

Márquez-Corro et al., 2020), so further studies are needed to confirm its phylogenetic placement within this section.

\section{Selected references}

Archer \& Balkwill, 1997. Márquez-Corro et al., 2020; Márquez-Corro \& Martín-Bravo, 2020.

\section{Conservation}

Previous assessments of the species performed at the national level in South Africa (Victor, 2002; Raimondo et al., 2009; SANBI, 2020) had consistently resulted in the category Vulnerable 
786

787

788

789

790

791

792

793

794

795

796

797

798

799

800

801

802

803

804

805

806

807

808

809

810

811

812

813

814

815

816

817

818

819

820

821

822

823

824

825

Carex badilloi Luceño \& Márquez-Corro, Phytotaxa 303(1): 36, 2017.

Type. South Africa. KwaZulu-Natal, Drakensberg mountains, Garden Castle Nature Reserve,

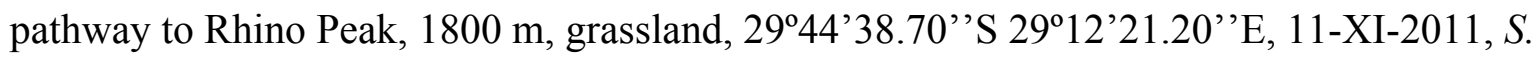
Martín-Bravo \& M. Luceño 96SMB11 (holotype: PRE!; iso-: NU-0049308!, UPOS-6576!).

- Schoenoxiphium ludwigii sensu Gordon-Gray (1995:168), non. Hochst. (1845:764).

Rhizome not or loosely caespitose, stout, dark-brown. Flowering culms (36)39-74(93) cm long, erect, obtusely trigonous, smooth, leafy up to lower two-thirds of its length, 2-3.1(3.2) mm wide at the middle. Leaves (3.7)4.5-6.5(9) $\mathrm{mm}$ wide, shorter than the inflorescence, moderately rigid, somewhat glaucous, slightly V-shaped in cross-section, scarcely to moderately scabrous along the edges and usually along the uppermost parts of the abaxial midrib; adaxial surface densely papillose; straight at the apex; ligule (0.8)1-3(3.5) mm long. Basal sheaths more or less entire, lowermost bladeless and uppermost with lamina. Lowest bract of the inflorescence leaf-like, much shorter than the inflorescence, with a sheath 35-49(63) cm long. Inflorescence branching up to 3 times. Partial inflorescences 4-7(8), uppermost subsessile and overlapping, lowermost more or less distant, pedunculate, more or less erect. Glumiform perigynia and glumiform cladoprophylls absent. Tubular cladoprophylls always present, those of the base of the first order branches terete, hyaline, those of the second order branches asymmetrically hypocrateriformis, somewhat hispid in the upper parts, more or less prominently veined and open. Utriculiform cladoprophylls sometimes present. Male glumes (2.9)3-4.4(4.9) $\times(1) 1.2-2.4(2.6) \mathrm{mm}$, ovate, yellowish-brown, with a green central band, ending in an aculeate mucro up to $0.2-1.7(3) \mathrm{mm}$ long. Female glumes (3.3)3.5-4.2 × (2.1)2.3-2.8(3.5) mm, widely ovate to suborbicular, yellowish-brown, with a green central band, ending in a light green, prominent, aculeate mucro up to $3.1 \mathrm{~mm}$ long. Unisexual utricles (4.3)4.7-5.3(5.4) $\times 1.7-2 \mathrm{~mm}$, ovoid to ellipsoid, straight, green to yellowish-brown when mature, hispid in the upper third or, very rarely, almost smooth, with prominent veins across the entire surface, suberect to erecto-patent; rachilla reaching the apex to protruding from it up to $0.5 \mathrm{~mm}$, abruptly contracted into an aculeate, bidentate to irregular beak 1.1-1.6(1.8) mm long; bisexual utricles wide and obliquely truncate at the apex. Achenes 3-3.3(3.5) $\times 1.4-1.9(2) \mathrm{mm}$, ovoid to ellipsoid, trigonous, straw-coloured to yellowishbrown when mature, tipped by a short, obtusely trigonous, persistent style base.

\section{Distribution}

Endemic to Drakensberg mountains in Lesotho (Qacha's Nek district) and South Africa (Eastern Cape and KwaZulu-Natal provinces) [27 CPP LES NAT]. Fig. 6B.

\section{Habitat}

Mesophilous, open grassland on clay soils in Grassland Biome (Drakensberg Grassland, Mesic Highveld Grassland); 1750-2500 m. 
826

827

828

829

830

831

832

833

834

835

836

837

838

839

840

841

842

843

844

845

846

847

848

849

850

851

852

853

854

855

856

857

858

859

860

861

862

863

864

865

\section{Etymology}

Named after Dr. Juan José González Badillo (1945-), Spanish researcher specialized in sport sciences at Universidad Pablo de Olavide (Seville, Spain).

\section{Iconography}

Figs. 8B and 9, Márquez-Corro et al. (2017, analytical drawing and photographs of living specimens in the field).

\section{Conservation}

Not evaluated (NE).

\section{Notes}

This species traditionally used to be called Schoenoxiphium ludwigii Hochst.; however, since the type of the latter name belongs to a different species (Schoenoxiphium rufum Nees, currently known as Carex ludwigii (Hochst.) Luceño \& Martín-Bravo; see Global Carex Group, 2015), the new species $C$. badilloi had to be described for this taxon (Márquez-Corro et al., 2017). The identity of $C$. badilloi has been well-supported by morphological (Márquez-Corro et al., 2017; this study) and molecular (Villaverde et al., 2017; Márquez-Corro et al., 2020; this study) data.

\section{Selected references}

Márquez-Corro et al. (2017).

\section{Carex basutorum (Turrill) Luceño \& Martín-Bravo, Bot. J. Linn. Soc. 179: 26, 2015.}

Type. [Lesotho] Basutoland. Plateau, Leribe Mount. Flowering season: summer, XII-1912, $A$. Dieterlen 948 (lectotype: K-000363525 digital image!, designated by Kukkonen (1983) ; iso-: PRE-0107825 digital image!, P-00540800 digital image! [sic. 1913]). 三 Schoenoxiphium basutorum Turrill, Bull. Misc. Inform. Kew 1914: 19, 1914 [basionym]

Rhizome caespitose, with short internodes, moderately stout, brown. Flowering culms (25)30$60(65) \mathrm{cm}$ long, acutely trigonous and smooth or scarcely scabrid at the apex, leafy usually up to upper third of its length, (0.6)0.9-1.4(1.5) mm wide at the middle. Leaves (0.3)1-1.5(2.3) mm wide, shorter, equaling or longer than the inflorescence, soft to scarcely rigid, light green, carinate or canaliculate, rarely trigonous or somewhat flat in cross-section, scabrid along the edges in all its length; abaxial surface smooth, except frequently in the midrib; adaxial surface smooth; trigonous and curled at the tip; ligule 1.5-3(3.7) $\mathrm{mm}$ long. Basal sheaths more or less fibrous, with lamina, but the lowest bladeless. Lowest bract of the inflorescence leaf-like, longer or, more rarely, shorter than the inflorescence, not sheathing. Inflorescence branching up to 2(3) 
866 times; partial inflorescences (3)5-8(10) overlapping or, rarely, the lowest somewhat distant; 867 sessile to shortly pedunculate, erect to suberect. Glumiform perigynia and glumiform

868 cladoprophylls absent. Tubular cladoprophylls present in the lowest partial inflorescence, rarely 869 absent, hyaline; utriculiform cladoprophylls always present. Male glumes 4.2-7 × 1.5-1.9 mm, 870 ovate to ovate-lanceolate, pale reddish-brown, with a narrow, green central band, acute,

871 acuminate to shortly aristate. Female glumes (4.1)4.8-6.3(6.8) × 1.7-2.2(2.4) mm, ovate, pale

872 reddish-brown, with a green central band, acute, acuminate or more frequently ending in a

873 smooth ariste up to $1 \mathrm{~mm}$. Unisexual utricles (5)6-7.2 $\times 0.7-1 \mathrm{~mm}$, narrowly linear, shortly

874 stipitate, straight or, very rarely, slightly arcuate, greenish, straw coloured to pale brown, densely

875 papillose-scabriuscule at least in the upper half, with numerous prominent veins across the entire

876 surface, erect to suberect, very gradually attenuated into an irregularly lacerate, asymmetrically

877 truncate, bidentate or bifid beak up to $2 \mathrm{~mm}$; rachilla protruding from the apex of the utricle up

878 to $1.5 \mathrm{~mm}$; bisexual utricles wide and obliquely truncate. Achenes (3.5)3.8-4.2 × 0.6-1 mm,

879 oblong-trigonous, yellowish-brown, tipped by a trigonous, acute, persistent style base.

880

881 Distribution

882 Endemic to Drakensberg and Winterhoek mountains in Lesotho (Leribe and Qacha's Nek

883 districts) and South Africa (Eastern Cape and Free State provinces) [27 CPP LES OFS]. Fig. 6C.

884

885

886 Grassland and scrub clearing in Grassland Biome (Drakensberg Grassland and Mesic Highveld 887 Grassland); 1500-2100 m.

888

889

890

891

892

893

894

895

896

897

898

899

900

901

902

903

\section{Etymology}

The epithet honours Basotho people, inhabitants of the country currently named Lesotho.

\section{Iconography}

Figs. 8C and 10.

\section{Conservation}

Not considered of conservation concern at the national level in South Africa, and thus categorized as Least Concern (LC) (SANBI, 2020; sub Schoenoxiphium basutorum).

904 designated; isolecto-: BOL-70348 digital image!). Syntype: Natal, Buchanan 328 (K-000693809

905 digital image!). 
906

907

908

909

910

911

912

913

914

915

916

917

918

919

920

921

922

923

924

925

926

927

928

929

930

931

932

933

934

935

936

937

938

939

940

941

942

943

944

945

=Carex parvirufa Luceño \& Márq.-Corro, Phytotaxa 303(1): 41, 2017.

Type. Lesotho, Leribe district, Pitseng, left side of the road in the ascent to the Mafika Lisiu Pass summit, $3101 \mathrm{~m}$, grasslands in the summit, 2903'58.30’S 28²4'27.10’E, 14 January 2014, T. Villaverde et al. 28TVH14 (holotype: PRE!; iso-: NU-0049310!, UPOS-8508!).

= Schoenoxiphium bracteosum Kukkonen, Notes Royal Botanic Garden Edinburgh 43: 365 (1986); non Carex bracteosa (Rchb.) Kunze ex Kunth (1837).

Type: [South Africa] Cape, Barkly East distr., Ben McDhi, 9000ft, in grass tussocks on hillside, 5-II-1983, Hilliard \& Burtt 16471 (holotype: H-1486367 digital image!; iso-: E-00200231 digital image!, GENT-0000090032912 digital image!, NU-0015688 digital image!).

Rhizome caespitose, with short internodes moderately stout, light-brown to dark-brown.

Flowering culms (4)12-67(95) cm long, erect, obtusely trigonous, smooth, occasionally with any minute prickle to the apex, leafy from one third to nearly half of its length, (0.3)0.8-1.2(1.5) mm wide at the middle. Leaves (0.5)1.7-3.8(5.5) mm wide, shorter, rarely longer (in dwarf plants) than the inflorescence, slightly to moderately rigid, straight at the apex, light-green to somewhat glaucous, flat to $\pm \mathrm{V}$-shaped in cross-section, slightly to moderately scabrous along the edges and usually along the abaxial midrib; adaxial surface usually finely papillose; ligule (0.5)0.8-3(4) $\mathrm{mm}$ long. Basal sheaths with lamina or, more rarely, the lowermost bladeless, entire, somewhat broken or slightly fibrous. Lowest bract of the inflorescence leaf-like, from half of the inflorescence length to equaling it, with a sheath (9)17-51(73) $\mathrm{mm}$ long. Inflorescence up to the upper $1 / 2$ of the length of the culm, branching up to 3(4) times; partial inflorescences (5)6-8(9), erect, the uppermost sessile, overlapping, the lowermost usually distant, long-pedunculate. Glumiform perigynia and glumiform cladoprophylls absent. Tubular cladoprophylls always present; utriculiform cladoprophylls usually present, similar to bisexual utricles. Male glumes $2.2-3(3.3) \times(1) 1.1-1.8(2) \mathrm{mm}$, ovate to obovate, yellowish-brown to brown, with a green central band, ending in an aculeate mucro up to $2 \mathrm{~mm}$ long. Female glumes 2-2.7(3.1) $\times(1.1) 1.3-2(2.1)$ $\mathrm{mm}$, ovate, yellowish-brown, with a green central band, ending in an aculeate mucro up to $2.8(3.1) \mathrm{mm}$ long, arising from the back, a little below the apex of the glume. Unisexual utricles (2) 2.5-3.6(4) $\times(0.6) 1-1.4(1.6) \mathrm{mm}$, ovoid to ellipsoid, stipitate, straight or, more rarely, slightly arcuate, straw-coloured to yellowish-brown when mature, dispersely aculeate to hispid in the upper third, with conspicuous prominent veins over the entire surface, suberect to erecto-patent, abruptly contracted into an aculeate, bidentate to irregular beak (0.3)0.5-1 mm long; rachilla reaching the apex to protruding from it up to $0.3(0.4) \mathrm{mm}$. Bisexual utricles usually present, widely and obliquely truncate at the apex. Achenes (1.2)1.4-2.2(2.5) $\times(0.7) 0.8-1.2(1.5) \mathrm{mm}$, ellipsoid-trigonous, straw-coloured to yellowish-brown when mature, tipped by a short, obtusely trigonous, usually asymmetric, persistent style base.

\section{Distribution}


946 Endemic to the Drakensberg and Central West of Eastern Cape mountains. Lesotho (Butha

947 Buthe, Maseru, Leribe, Qacha's Nek and Thaba Tseka districts) and South Africa (Eastern Cape,

948 Free State and KwaZulu-Natal). [27 CPP LES NAT OFS]. Fig. 6D.

949

950

951

\section{Habitat}

952

Edges of streams, grasslands, damp meadows and open bushy places (Grassland Biome:

953

954 Drakensberg Grassland); (1200)1650-3150 m.

955 Named after Harry Bolus (1834-1911), South African botanist and philanthropist who founded 956 the Bolus Herbarium (BOL) in 1865.

957

958

959

Iconography

960

Figs. 8D and 11, Márquez-Corro et al. (2017, analytical drawing and photographs of living

961

962 specimens in the field).

963 Not evaluated (NE).

964

965

966

967

968

969

970

971

972

973

974

975

976

977

\section{Notes}

The name C. bolusii C.B.Clarke has been considered synonymous with C. schimperiana Boeckeler (a synonym of $C$. spartea Wahlenb.; Global Carex Group, 2015). However, the type materials indicated by Clarke (Bolus 1974, K-000693810 and Buchanan 328, K-000693809) contain specimens of $C$. parvirufa Luceño \& Márq.-Corro, a species recently described (Márquez-Corro et al., 2017); so, by the principle of priority (ICN, 2018), the correct name of these plants should be the earlier C. bolusii C.B.Clarke. Kukkonen (in label) designated as lectotype the voucher Bolus 1974 and left as residual syntype the specimen Buchanan 328, but such typifications were never effectively published. For this reason, we have selected here as lectotype the voucher Bolus 1974, and as syntype the voucher Buchanan 328. Moreover, after a thorough examination of the type materials from Schoenoxiphium bracteosum Kukkonen (E, GENT, NU) and a detailed reading of the protologue, we believe that the binomen must be

978 considered as synonym of $C$. bolusii C.B.Clarke, contrary to a previous publication (Global Carex Group, 2015), in which it was synonymized under C. schimperiana Boeckeler (a synonym

980 of $C$. spartea) circumscription. This is based on the slightly fibrous basal sheaths of the type

981 materials, as typically occurs in $C$. bolusii, and not completely fibrous, as shared by the $C$.

982 spartea specimens. Moreover, the leaf and culm width are similar to the measurements observed

983

984 in C. bolusii.

985

\section{Selected references}

Márquez-Corro et al. (2017). 
986

987

988

989

990

991

992

993

994

995

996

997

998

999

1000

1001

1002

1003

1004

1005

1006

1007

1008

1009

1010

1011

1012

1013

1014

1015

1016

1017

1018

1019

1020

1021

1022

1023

1024

1025

Carex burkei (C.B. Clarke) Luceño \& Martín-Bravo, Bot. J. Linn. Soc. 179: 26, 2015.

इ Schoenoxiphium burkei C.B.Clarke, J. Linn. Soc. Bot. 20: 386, 1883 [basionym]

Type: South Africa. Eastern Cape, Cradock Div. [Inxuba Yethemba Local Municipality], Burke 211 (lectotype: K-000693801 digital image!, designated by Gordon-Gray (1995)).

Rhizome loosely caespitose to caespitose, with short internodes, scarcely to moderately stout, dark-brown. Flowering culms (29)40-80(93) cm long, acutely trigonous, more or less scabrid to the apex, leafy from lower one-third to two-thirds of its length, (1)1.3-2.3(3) mm wide at the middle. Leaves (1.5)2.5-4.5(5.5) mm wide, shorter than the inflorescence, coriaceous, light green to somewhat glaucous, flat to, more rarely, carinate in cross-section, strongly scabrous along the edges and usually also along the abaxial midrib; adaxial surface papillose on the veins, especially in the upper half; tip usually very curled, ligule $0.5-4(7) \mathrm{mm}$ long. Basal sheaths entire, with lamina. Lowest bract leaf-like, shorter than, rarely equaling, the inflorescence, with a sheath (19)30-60(80) mm long. Inflorescence branching up to 4 times; partial inflorescences (3)7-10(13), uppermost overlapping, sessile, lowermost distant, with scabrid peduncles up to 11 $\mathrm{cm}$ long, suberect. Glumiform perigynia and glumiform cladoprophylls absent. Tubular cladoprophylls present at the base of some peduncles, hyaline-brownish; utriculiform cladoprophylls always present, usually numerous. Male glumes 3-4.5(5.1) × 1.3-2.2(2.5) mm, ovate to obovate, yellowish-brown with a green central band and, frequently, with a wide hyaline margins, acute or ending in an aculeate mucro or arista up to $0.8 \mathrm{~mm}$ long. Female glumes (3)3.2-4(4.1) × 1.6-2.3(2.6) $\mathrm{mm}$, ovate, obovate or elliptic, with scarious margin, yellowishbrown to light-brown with a green central band, acute or with an mucro or ariste up to $1.5(2) \mathrm{mm}$ long. Unisexual utricles (3.3)4.1-4.5(5) $\times(0.9) 1.1-1.3 \mathrm{~mm}$, narrowly ellipsoid or, more rarely, narrowly suboblong, stipitate, straight, green to yellowish-brown when mature, more or less hispid in the upper half, rarely subglabrous, with numerous prominent veins across the entire surface, suberect, gradually attenuate into a bidentate, obliquely truncate or irregularly lacerate beak up to $1 \mathrm{~mm}$ long; rachilla reaching the apex of the utricle or, more rarely, protruding from the mouth up to $0.5 \mathrm{~mm}$, sometimes bearing some small, sterile glumes at the tip. Bisexual utricles ending in a beak wide and obliquely truncate. Achenes (2.3)2.5-3.1 $\times 0.8-1 \mathrm{~mm}$, narrowly ellipsoid-trigonous to oblong-trigonous, yellowish-brown when mature, tipped by a very short and wide, obtusely trigonous, persistent, style base.

\section{Distribution}

Endemic to Lesotho (Leribe, Mokhotlong, Qacha's Nek and Thaba Tseka districts) and South Africa (Eastern Cape, KwaZulu-Natal, Free State and Western Cape provinces). [27 CPP LES NAT OFS]. Fig. 6E.

PeerJ reviewing PDF | (2021:02:57694:1:1:NEW 25 Mar 2021) 


\section{Habitat}

1027 Grassland, clearing of shrubland, usually in dry places, but sometimes in temporary flooded

1028 meadows and edges of streams (Grassland Biome: Drakensberg Grassland); 1400-2900 m.

1029

1030

\section{Etymology}

1031 Named after Joseph Burke (1834-1911), British explorer who collected animals and plants for 1032 Edward Smith-Standley (Lord Derby) in South Africa between 1840 and 1842.

1033

1034

\section{Iconography}

1035 Figs. 8E and 12.

1036

1037

\section{Conservation}

1038 Not evaluated (NE).

1039

1040

1041

Carex capensis Thunb., Prodr. Pl. Cap.: 14, 1794.

1042

1043 Type. Cap. b. Spei (lectotype UPS-21777, digital image!, specimen on the left, here designated)

1044 三Schoenoxiphium thunbergii Nees, Linnaea 9: 305, 1834.

$1045 \equiv$ Archaeocarex thunbergii (Nees) Pissjauk., Bot. Mater. Gerb. Bot. Inst. Komarova Akad. Nauk 1046 S.S.S.R. 12: 83, 1950.

1047

1048 = Schoenoxiphium ecklonii Nees, Linnaea 10: 200, 1835 [1836].

1049 Type: [South Africa] 'Adowhúgel, 3' et., 'Distr. Uitenhagen,' Oct. 1829, Ecklon \& Zeyher 909

1050 (lectotype: SAM, designated by Kukkonen (1983); isolecto-: S; see notes below)

$1051 \equiv$ Archaeocarex ecklonii (Nees) Pissjauk., Bot. Mater. Gerb. Bot. Inst. Komarova Akad. Nauk

1052 S.S.S.R. 12: 83, 1950.

1053 三Kobresia ecklonii (Nees) T.Koyama, J. Fac. Sci. Univ. Tokyo, Sect. 3, Bot. 8: 80, 1961.

$1054=$ Carex bisexualis C.B.Clarke in Harvey \& auct. suc. (eds.), Fl. Cap. 7: 302, 1898.

1055 Type: [South Africa] In Cap. Buona Spei, Ecklon 853 (lectotype: C-10000624 digital image!,

1056 here designated) Syntype: Lions rump, near Cape Town, Pappe (K-000693803 digital image!)

1057 = Schoenoxiphium ecklonii var. unisexuale Kük. in Engler, Pflanzenr. 38(IV, 20): 33, 1909.

1058 Type: [South Africa] In Cap. Buona Spei, Ecklon 853 (lectotype: C-10000624 digital image!, 1059 here designated)

1060 = Carex zeyheri C.B.Clarke in Harvey \& auct. suc. (eds.), Fl. Cap. 7: 303, 1898.

1061 Type: Swellendam Div., on mountains along the lower part of Zonder Einde river, 500-2000 ft.,

1062 Zehyer 4441 (lectotype: K-000693804 digital image!, here designated, isolecto-: FI-001040

1063 digital image!, LE-000434 digital image!, LE-00010433 digital image!, P-00540798 digital

1064 image!, P-540799 digital image!, E-00286073 digital image!, S-10-1167).

1065 
1066 Rhizome lax to densely caespitose, with short internodes, moderately stout, dark-brown.

1067 Flowering culms (5.5)12-30(42) cm long, erect, obtusely trigonous, smooth, leafy up to lower

1068 third of its length, (0.7)0.8-1.5 mm wide at the middle. Leaves (1.5)2-3(3.8) mm wide, shorter

1069 than the inflorescence, somewhat rigid, light green to glaucous, flat to carinate in cross-section,

1070 scabrous along the edges and sometimes also along the abaxial midrib; adaxial surface smooth;

1071 straight to curled at the apex; ligule (0.5)0.7-1.6(2.5) mm long. Basal sheaths more or less

1072 fibrous, bladeless. Lowest bract of the inflorescence (and frequently the next one) leaf-like,

1073 longer than the inflorescence, not sheathing. Inflorescence ovoid to shortly oblong, branching up

1074 to 3 times; partial inflorescences 4-6(8), overlapping, rarely the lowest distant, sessile.

1075 Glumiform perigynia and glumiform cladoprophylls absent. Tubular cladoprophylls always

1076 present at the base of the partial inflorescences, hyaline; utriculiform cladoprophylls usually

1077 present in lower parts of developed inflorescences. Male glumes (3)3.5-4(4.6) $\times 1.3-2.2 \mathrm{~mm}$,

1078 ovate-lanceolate to ovate, occasionally elliptic, light to yellowish-brown with a green central

1079 band, acute, rarely obtuse or very shortly acuminate. Female glumes (3)3.5-4.5(4.9) × 1.6-

$10802.3(2.5) \mathrm{mm}$, ovate to ovate-lanceolate, with scarious margin, yellowish to dark brown with a

1081 green central band, acute to shortly acuminate. Unisexual utricles (3.5)4-5.1(5.8) $\times 1-1.4(1.5)$

$1082 \mathrm{~mm}$, oblong to narrowly ellipsoid to ovoid, long-stipitate, straight, straw-coloured to yellowish-

1083 brown when mature, more or less hispid in the upper third, with numerous prominent veins

1084 across the entire surface, suberect, gradually attenuate into a bidentate or slightly bifid beak up to

$10851 \mathrm{~mm}$ length; rachilla reaching the apex of the utricle or, more rarely, protruding from the mouth

1086 and bearing some small, sterile glumes at the tip, but then wide and obliquely mouthed. Bisexual

1087 utricles widely and obliquely truncate at the apex. Achenes (3)3.2-3.6(4.1) $\times(0.7) 1-1.1(1.4)$

$1088 \mathrm{~mm}$, narrowly ellipsoid-trigonous to almost oblongoid, yellowish-brown when mature, tipped by

1089 a very short and wide, obtusely trigonous, persistent, style base.

1090

1091 Distribution

1092 Endemic to Cape region (Eastern and Western Cape provinces), South Africa. [27 CPP]. Fig. 6F.

1093

1094 Habitat

1095 Open and sunny places on shale soils, commonly observed in after-fire vegetation (Fynbos

1096 Biome: mostly in Renosterveld). 5-750 m.

1097

1098

\section{Etymology}

1099 From the latin capens-is, from the Cape, in reference to the South African region where it was

1100 discovered and to where it is endemic.

1101

1102 Iconography

1103 Figs. 8F and 13. Kükenthal (1909, sub Schoenoxiphium ecklonii).

1104

1105 Conservation 
1106 Considered as Least Concern (LC) at the national level in South Africa (SANBI, 2020; sub 1107 Schoenoxipium ecklonii).

1108

1109

1110

Notes

1111

We have been unable to locate the lectotype of Schoenoxiphium ecklonii Nees, designated by

1112 Kukkonen (1983). Kukkonen considered this species as distinct (Kukkonen, 1983), as also

1113 confirms the revision labels he left in numerous herbarium specimens (M.L., pers. obs.). After

1114 the examination of the type of $C$. capensis Thunb., we consider $S$. ecklonii to be a synonym of the former, in view of the multiple specimens revised by Kukkonen whose taxonomic identity matches that of the $C$. capensis type. In addition we have located a number of potential syntypes of S. ecklonii that belong to C. capensis ([South Africa], Zwartkopsrivier, August, Ecklon \& Zeyher 4440, SAM-0023405 digital image!, second specimen from the left in the upper middle half; Uitenhage, Grassrug, Kalksteinhaltige, grasreiche flächen \& Hügelsnischen, Koega \& Zondagsrivier, 500-1000 ft., 15-VIII, Ecklon \& Zeyher, S-101142).

Carex chermezonii Luceño \& Martín-Bravo, Bot. J. Linn. Soc. 179: 27, 2015. Curtis (1782). Type. Madagascar. Mont Tsaratanana, 2500 m, X-1912, Perrier de la Bâthie, 2502 (holotype: P00536708 digital image!).

1128

1129

1130

Rhizome caespitose, moderately stout, brown. Flowering culms $29-51 \mathrm{~cm}$ long, erect, obtusely trigonous, scabrid to the apex, leafy up to $1 / 3$ of its length, $1-1.2 \mathrm{~mm}$ wide at the middle. Leaves 1.6-4.2 mm wide, shorter than the inflorescence, moderately rigid, more or less glaucous, flat in cross-section, straight at the apex; ligule not measured. Basal sheaths not or scarcely fibrous, usually with lamina, but those of the sterile shoots bladeless. Lowest bract leaf-like, longer than the inflorescence, not sheathing. Inflorescence c. $1 / 3$ of the length of the culm, branching up to 3 times; partial inflorescences $2-5$, the lowest short-pedunculate and more or less distant, the upper sessile to shortly pedunculate and overlapping. Glumiform perigynia and glumiform cladoprophylls not seen. Tubular cladoprophylls not seen. Utriculiform cladoprophylls present. Male glumes up to $4.5 \mathrm{~mm}$ long, lanceolate to ovate, yellowish-brown to brown, with a green central band, acute to acuminate. Female glumes $3.4-4.5 \mathrm{~mm}$ long, ovate, yellowish-brown to brown, shortly aristate, with a green central band. Unisexual utricles $4.9-7 \times 0.6-0.8 \mathrm{~mm}$, linear to narrowly ellipsoid, stipitate, strongly arcuate to straight, straw-coloured to yellowish-brown when mature, with numerous prominent veins across the entire surface, suberect, gradually attenuate into an obliquely truncate beak up to $2 \mathrm{~mm}$ long; rachilla reaching to slightly protruding from the apex of the utricle; bisexual utricles with the beak widely and obliquely truncate. Achenes up to $6 \mathrm{~mm}$ long, oblong. 
1146

1147

1148

1149

1150

1151

1152

1153

1154

1155

1156

1157

1158

1159

1160

1161

1162

1163

1164

1165

1166

1167

1168

1169

1170

1171

1172

1173

1174

1175

1176

1177

1178

1179

1180

1181

1182

1183

1184

1185

\section{Distribution}

Endemic to N Madagascar (Tsaratanana mountains), only known from the type collection. [29 MDG]. Fig. 6G.

\section{Habitat}

Montane forest; c. $2500 \mathrm{~m}$.

\section{Etymology}

Named after Henri Chermezon (1885-1939), French botanist specialized in tropical sedges, mainly from Madagascar. He was who originally described this species.

\section{Conservation}

Not Evaluated (NE).

\section{Notes:}

To our knowledge, the only known collection of this species are those of the type material, which consists of two specimens in whose photograph (P-00536708) we have relied on the preparation of this description. Our measurements match those contained in the protologue (Chermezon, 1923), but differ significantly from those published by Kukkonen (1983). This is especially pronounced regarding the length of the fertile culms and of the achenes. We have taken this last character from the author of the species, who was astonished by the unusual length $(6 \mathrm{~mm})$ of the fruit and used this character to differentiate $C$. chermezonii from $C$. multispiculata (Chermezon, 1923).

Carex distincta (Kukkonen) Luceño \& Martín-Bravo, Bot. J. Linn. Soc. 179: 27, 2015. इ Schoenoxiphium distinctum Kukkonen, Bot. Not. 131: 263, 1978 [basionym].

Type: Lesotho. Between Indumeni Dome and Castle Buttress, locally common in alpine grassveld on summit of Drakensberg, 9800', 10-XII-1957, Killick 2274 (holotype: BM000922721 digital image!; iso-: K-000363524 digital image!, PRE-0107831 digital image!.

Rhizome caespitose, with short internodes, slender, brown. Flowering culms (10)15-40(64) cm long, obtusely trigonous, smooth or very scarcely aculeate at the apex, leafy usually up to upper third of its length, (0.5)1-1.3(1.4) mm wide at the middle. Leaves (0.2)1.3-2.8(3.2) mm wide, shorter than the inflorescence, soft to scarcely rigid, light green, canaliculate, carinate or, more rarely, flat in cross-section, scabrous along the edges, at least in the distal half; abaxial surface smooth, except in the distal parts of the midrib; adaxial surface smooth; trigonous and usually curled at the apex; ligule (1)1.5-2 mm long. Basal sheaths not or scarcely fibrous, with lamina, more rarely the lowest bladeless. Lowest bract of the inflorescence leaf-like, shorter or, exceptionally, little longer than the inflorescence, with a sheath 18-37 mm long. Inflorescence 
1186 branching up to 3 times; partial inflorescences 1-4(5) distant; lateral subsessile to long1187 pedunculate, erect to suberect; terminal more or less oblong, with the first-order branches more 1188 or less distichous. Glumiform perigynia and glumiform cladoprophylls absent. Tubular 1189 cladoprophylls always present except in the terminal partial inflorescence, hyaline; utriculiform 1190 cladoprophylls always present. Male glumes 3.1-4.2(5) $\times 1.2-1.5(1.9) \mathrm{mm}$, ovate, ovate1191 lanceolate to elliptical, reddish-brown with a green central band, acute to shortly acuminate, 1192 rarely obtuse. Female glumes (2.8)3.2-4.3(4.5) × (1.3)1.4-1.8(2) mm, ovate, dark reddish-brown 1193 with a green central band, acute to acuminate, occasionally with a scabrid acumen up to $1 \mathrm{~mm}$. 1194 Unisexual utricles (3.2)3.7-4(4.1) $\times 0.7-1 \mathrm{~mm}$, linear-oblongoid to narrowly elipsoid, distinctly 1195 stipitate, straight, straw-coloured to yellowish-brown when mature, smooth or disperse and 1196 shortly aculeate at the apex, with numerous prominent veins across the entire surface, erect to 1197 suberect, gradually attenuated into a more or less bidentate beak $0.6-1 \mathrm{~mm}$; rachilla reaching or protruding a little from the apex of the utricle or, more rarely, much protruding from the mouth and bearing some small, sterile glumes at the top, but then, utricles wide and obliquely truncate; bisexual utricles wide and asymmetrically truncate. Achenes $(2.1) 2.3-2.8(2.9) \times 0.6-1 \mathrm{~mm}$, oblong-trigonous, yellowish-brown, tipped by a short, obtusely trigonous, persistent style base.

\section{Distribution}

Endemic to Drakensberg and the northeast mountains of Western Cape. Lesotho (Leribe, Maseru, Mohale's Hoek, Mokhotlong and Qacha's Nek) and South Africa (Eastern Cape, KwaZulu-Natal and Western Cape provinces). [27 CPP LES NAT]. Fig. 6H.

\section{Habitat}

1209

Open, stony and usually dry meadows and shrubland at high altitudes (Grassland Biome: Drakensberg Grassland); 1750-3000 m.

1211

1212

\section{Etymology}

1213 From the latin distinctus-a-um, distinct, distinguishable to the eye, probably because the species 1214 is easily recognizable because of its aspect.

1215

1216

1217 Figs. 8G and 14. Kukkonen (1978).

1218

\section{Conservation}

1220 Considered as Least Concern (LC) at national level in South Africa (SANBI, 2020; sub

1221 Schoenoxipium distinctum). 
1226 Type. [South Africa] Zuurbergen, Bontjesrivier-Strubels, 2500-3000', 4-XI-1829, Drège 2033a

1227 (lectotype: P-00540802 digital image!, here designated). Syntypes: [South Africa] Afr. austr.,

1228 Zuurberg range, Alexandria Div., July, 2000-3000 ft., Drège 1040 (K-000693805 specimen in

1229 the upper left corner, digital image!); [South Africa] S Africa, Zuurberg range, Alexandria Div.,

1230 July, 2000-3000 ft., Drège s.n. (K- 00363530 specimen in the left, digital image!)

1231

1232

इ Schoenoxiphium caricoides C.B.Clarke, Bull. Misc. Inform. Kew, Addit. Ser. 8: 67 (1908).

1233

इ Schoenoxiphium kunthianum Kük. in Engler (ed.), Pflanzenr. 38(IV, 20): 31 (1909).

1234

$\equiv$ Archaeocarex kunthiana (Kük.) Pissjauk., Bot. Mater. Gerb. Bot. Inst. Komarova Akad. Nauk

1235 S.S.S.R. 12: 83 (1950).

1236 इ Kobresia kunthiana (Kük.) T. Koyama, J. Fac. Sci. Univ. Tokyo, Sect. 3, Bot. 8: 80 (1961).

1237

1238

Rhizome caespitose, with short internodes, moderately stout, dark-brown. Flowering culms

1239 (15)20-50(60) cm long, erect, more or less acutely trigonous, smooth, leafy up to lower twothirds of its length, (0.5)0.8-1.2(1.6) $\mathrm{mm}$ wide at the middle. Leaves (0.9)1.5-3.2(3.5) mm wide, shorter than the inflorescence, moderately rigid, light green, flat to carinate or canaliculate in cross-section, scabrous along the edges and usually also along the abaxial midrib; adaxial surface smooth, sometimes very sparsely aculeate towards de apex, straight or, very rarely, curved to curled; ligule (0.6)0.8-5(8) $\mathrm{mm}$ long. Basal sheaths with lamina, densely fibrous. Lowest bract of the inflorescence leaf-like, shorter than the inflorescence length, usually much widened at the base and with scarious margin, as the remaining bracts, with a sheath (8)15-30(32) $\mathrm{mm}$ long. Inflorescence up to the upper $1 / 2$ of the length of the culm, branching up to 3 times; partial inflorescences 3-5(7), erect, the 1-3 lowermost distant, pedunculate, the (2)3-4 uppermost overlapping, subsessile, rarely all subsessile and overlapping. Glumiform perigynia and glumiform cladoprophylls absent. Tubular cladoprophylls always present at the base of the peduncles, hyaline-brownish; utriculiform cladoprophylls very rarely present. Male glumes (2)2.5-3.8(4.1) $\times(1) 1.5-2.1(2.3) \mathrm{mm}$, ovate to elliptical, yellowish-brown, ending in an aculeate mucro or arista up to $1.3 \mathrm{~mm}$ long. Female glumes (2)2.5-4(5.2) $\times(1.2) 1.7-2.6(2.8) \mathrm{mm}$, ovate to suborbicular, yellowish to yellowish-brown, ending in an aculeate mucro up to 3(4) $\mathrm{mm}$ long. Unisexual utricles (2.1)2.5-3.5(4) $\times 1.1-1.9 \mathrm{~mm}$, ovate to ellipsoid, stipitate, straight, strawcoloured to yellowish-brown when mature, glabrous, smooth or, exceptionally, with some scattered pricklets, with numerous prominent veins across the entire surface, more or less suberect, abruptly contracted in a bidentate to irregularly truncate, smooth, minute beak up to 0.3 $\mathrm{mm}$ length; rachilla rudimentary to reaching up to $1 / 2(2 / 3)$ of the utricle. Bisexual utricles very rare, widely and obliquely truncate at the apex. Achenes $2-3(3.2) \times 1-1.5(1.7) \mathrm{mm}$, ellipsoidtrigonous, dark brown when mature, tipped by a very short, obtusely trigonous, persistent style base.

\section{Distribution}


1265 Eastern and southern parts of Africa and Madagascar with a disjunct population in Western

1266 Angola. Angola (Benguela province), Eswatini (HhoHho district), Kenya (Kericho and Trans

1267 Nzoia counties), Lesotho (Leribe and Qacha's Nek districts), Madagascar (Fianarantsoa

1268 province), South Africa (Eastern Cape, Free State, KwaZulu-Natal, Mpumalanga, Northwest and

1269 Western Cape provinces), Tanzania (Rukwa and Ruvuma regions), Uganda (Northern region)

1270 and Zimbabwe (Manicaland province). [25 KEN TAN UGA 26 ANG ZIM 27 CPP LES NAT

1271 OFS SWZ TVL 29 MDG]. Fig. 15A.

1272

1273

\section{Habitat}

1274 Dry to damp grassland and grassy clearing of shrubs (mainly in Grassland Biome, more rarely in 1275

1276 Albany Thicket, Indian Ocean Coastal Belt and Savanna biomes) and extending into

1277

1278 afromontane areas of tropical Africa; 200-2850 m.

1279

\section{Etymology}

1280

Named after Johann Franz Drège (1794-1881), German (with Huguenot ancestry) botanist and

1281 explorer, who collected c. 8000 species and c. 200000 specimens throughout the present Eastern

1282

1283 Cape, KwaZulu-Natal, Northern Cape and Western Cape provinces, between 1826 and 1832.

\section{Iconography}

1285

1286

Figs. 16 and 17A. Haines \& Lye (1983, sub Schoenoxiphium caricoides).

\section{Conservation}

1288

1289

Due to the long-standing problems concerning delimitation of this species, it has not previously been evaluated under the taxonomic concept here proposed, and should therefore be considered Not Evaluated (NE).

1290

1291

\section{Notes}

1292 C. dregeana is the only species in the section whose rachilla does not reach the apex of the unisexual utricles and, moreover, they are frequently reduced to a barely visible, vestigial elongation of the branch at the base of the utricle. This species is easily recognizable both for that peculiarity and for the very rare presence of bisexual utricles and utriculiform cladoprophylls. Another character that allows the correct identification of this species from the similar ones, as C. spartea and C. esenbeckiana, is the utricle beak length, that does not lengthen beyond $0.3 \mathrm{~mm}$. In addition, the upper partial inflorescence bracts usually present a wide base and an evident scarious margin, that elongates in a subulate apex. This species hybridizes with certain frequency with $C$. spartea, resulting in numerous intermediate morphotypes, characterised by the rachillas that do not reach the apex of the utricle, bisexual utricles sometimes present, bracts not or slightly widened at the base, and utricle beak up to $0.6 \mathrm{~mm}$. section). 
1305 We have designated the lectotype of $C$. dregeana Kunth on a specimen from P, where Kunth was

1306

1307

1308

1309

1310

1311

1312

1313

1314

1315

1316

1317

1318

1319

1320

1321

1322

1323

1324

1325

1326

1327

1328

1329

1330

1331

1332

1333

1334

1335

1336

1337

1338

1339

1340

1341

1342

1343

1344

established (Stafleu \& Cowan 1976). Our designation intends to conserve the current usage of

the name. There are a number of specimens also collected by Drège in South Africa, and bearing a label probably handwritten by Kunth but their labels are not a perfect match to the one of the selected lectotype, so we have considered such material as syntypes.

Carex esenbeckiana Boeckeler, Linnaea 40: 372 (1876)

इUncinia lehmannii Nees, Linnaea 10: 206 (1836), non Carex lehmannii Drejer (1844).

Type: [South Africa] In montibus prope urban Cape, Ecklon \& Zehyer site 85 [Plantae capenses. "Cap, östlicher Abhang des Tafelberges, bei Konstantia" (see Drège, 1847a: 258)] (lectotype: S10-1129 digital image!, designated by Kukkonen (1983)).

इSchoenoxiphium lehmannii (Nees) Kunth ex Steud., Syn. Pl. Glumac. 2: 245 (1855).

इ Schoenoxiphium sparteum var. lehmannii (Nees) Kük. in Engler, Pflanzenr. 38(IV, 20): 32 (1909).

इ Kobresia lehmannii (Nees) T.Koyama, J. Fac. Sci. Univ. Tokyo, Sect. 3, Bot. 8: 80 (1961).

$=$ Carex uhligii K.Schum. ex C.B.Clarke, Bot. Jahrb. Syst. 38(2): 136, 1907.

Type: Tanzania, Usambara, zwischen Mbalu und Mlalo, XII-1901, Uhlig 856 (lectotype: EA s.n. digital image!, here designated).

Rhizome densely caespitose, with very short internodes, moderately stout, dark-brown. Flowering culms (10)40-70(90) cm long, more or less acutely trigonous, smooth to slightly scabrous, leafy up to $1 / 10(1 / 4)$ of its length, (0.6)0.8-1.1(1.3) $\mathrm{mm}$ wide at the middle. Leaves (0.9)2-5(7) mm wide, shorter, more rarely equaling, than the inflorescence, soft to very slightly rigid, straight to scarcely curved at the apex, light green, flat, more rarely, scarcely canaliculate, carinate or plicate in cross-section, scabrous along the margins and along the abaxial midrib to the apex, mainly in the upper half; adaxial surface smooth or somewhat aculeate; ligule (0.9)1.52.5(3.4) $\mathrm{mm}$ long. Basal sheaths with lamina, more rarely lowermost bladeless, moderately to densely fibrous. Lowest bract of the inflorescence leaf-like, shorter, rarely longer, than the inflorescence, with a sheath (7)15-30(44) mm long. Inflorescence up to the upper $85 \%$ of the length of the culm, branching up to 2(3) times; partial inflorescences (6)7-10(12), all distant and pedunculate, except the 2(3) uppermost, that are subsessile and overlapping; peduncles included in the sheaths or slightly protruding from it. Glumiform perigynia and glumiform cladoprophylls absent. Tubular cladoprophylls always present. Utriculiform cladoprophylls rarely present. Male glumes (1.7)2-3.5(3.9) $\times(0.6) 1.5-2 \mathrm{~mm}$, widely ovate to oblong, straw-coloured to yellowishbrown, with a green central band, acute to ending in an aculeate mucro up to 0.3(2) $\mathrm{mm}$ long. Female glumes (1.8)2-3.5(3.7) $\times(1) 1.5-1.9(2.1) \mathrm{mm}$, ovate, straw-coloured to, more frequently, pale reddish brown, with a green central band, acute to ending in an aculeate mucro up to $3 \mathrm{~mm}$

PeerJ reviewing PDF | (2021:02:57694:1:1:NEW 25 Mar 2021) 
1345 long. Unisexual utricles (3.1)3.8-5.5(6) $\times(1) 1.1-1.5(1.9) \mathrm{mm}$, widely ovoid to ellipsoid, long1346 stipitate, straight, more rarely slightly curved, straw-coloured to brownish when mature, smooth, 1347 with conspicuous prominent veins over the entire surface, suberect to erecto-patent, very abrutly 1348 contracted, into a smooth, bidentate to irregularly truncate beak (0.7)1.3-2(2.3) mm long; 1349 rachilla reaching the apex of the utricle or, more frequently protruding from it up to $0.5(1) \mathrm{mm}$. 1350 Bisexual utricles very rare, althoug ocasionally predominant in some individuals, widely and 1351 obliquely truncate at the apex. Achenes (2.1)2.3-2.7(3) $\times(1.2) 1.3-1.5(1.6) \mathrm{mm}$, ellipsoid1352 trigonous, more or less straw-coloured to brown when mature, tipped by a short, obtusely 1353 trigonous, distinctly neck-like, rarely asymmetric, persistent style base.

1354

1355

1356

1357

1358

1359

1360

1361

1362

1363

1364

1365

1366

1367

1368

1369

1370

1371

1372

1373

1374

1375

1376

1377

1378

1379

1380

1381

1382

1383

1384 Carex gordon-grayae Luceño, Márquez-Corro \& Sánchez-Villegas, sp. nov. 
1385

1386

1387

1388

1389

1390

1391

1392

1393

1394

1395

1396

1397

1398

1399

1400

1401

1402

1403

1404

1405

1406

1407

1408

1409

1410

1411

1412

1413

1414

1415

1416

1417

1418

1419

1420

1421

1422

1423

Diagnosis: Similar in appearance to $C$. esenbeckiana Boeckeler, from which it differs by its wider leaves ((4.5)5.5-9 $\mathrm{mm}$ in C. gordon-grayae vs. (0.9)2-5(7) $\mathrm{mm}$ in C. esenbeckiana), the utricles (5.4-7.9 mm long, linear-oblong to narrowly ellipsoid, gradually attenuated in the beak in C. gordon-grayae vs. (3.1)3.8-5.5(6) mm long, ovoid to broadly ellipsoid, abruptly contracted in the beak utricles in $C$. esenbeckiana), and by its broadly pyramidal style base in $C$. gordongrayae vs. shortly trigonous, neck-like style base in C. esenbeckiana.

Holotype: South Africa. KwaZulu-Natal, Port Shepstone, Baboon Spruit district, Oribi Gorge, II1973, L.E. Davidson 2649 (NU-0002643-0!). Paratypes: South Africa, Eastern Cape, Hagga-

Hagga district, marsh, 7-II-1995, B. Sonnenberg 446 (NU-s.n.!). Ibidem, Kentani, 32³0'7.628”S 28²0'9.499'E, edge of stream in forest, 4-IV-1904, A.M. Pegler 1097 (BOL-4655 digital image! ).

Rhizome laxly caespitose, with short internodes, moderately stout, medium to dark-brown. Flowering culms 29.5-65 cm long, obtusely trigonous, smooth, leafy up to half of its length, 0.9$1.7 \mathrm{~mm}$ wide at the middle. Leaves (4.5)5.5-9 mm wide, shorter than the inflorescence, somewhat rigid, glaucous, flat in cross-section, scabrous along the edges, at least in the upper two-thirds; abaxial surface smooth, but scabrous in the upper third of the mibrid; adaxial surface papillose-aculeate near the margins of the distal half, straight at the apex; ligule $4.5-5.3 \mathrm{~mm}$ long. Basal sheaths broken to slightly fibrous, lowermost bladeless. Lowest bract of the inflorescence leaf-like, shorter than the inflorescence length, with a sheath 20-40 mm long. Inflorescence branching up to three times; partial inflorescences 3-5, very distant, except terminal ones; lateral from subsessile to shortly pedunculate, erect. Glumiform perigynia and glumiform cladoprophylls absent. Tubular cladoprophylls always present at the base of partial inflorescences and in some first order branches of lateral partial inflorescences, hyaline; utriculiform cladoprophylls usually present at lower parts of developed partial inflorescences. Male glumes $2.9-4.2 \times 0.9-1.4 \mathrm{~mm}$, lanceolate to ovate, hyaline, with a green central band, acute to acuminate, usually with a scabrid acumen up to $1.1 \mathrm{~mm}$ long. Female glumes $4-6.5 \times$ 1.3-1.9 mm, lanceolate to ovate, hyaline, with a narrow, green central band, with a scabrid acumen up to $2.5 \mathrm{~mm}$ long. Unisexual utricles 5.4-7.9 $\times(0.9) 1.1-1.5 \mathrm{~mm}$, linear-oblong to narrowly-ellipsoid, shortly stipitate, straight to very slightly curved, green to yellowish brown when mature, sparsely aculeate at the apex of the beak, with numerous prominent veins across the entire surface, erect, gradually attenuated into an obliquely truncate, hyaline at the apex beak 1.4-2.5 mm long; rachilla protruding from the apex up to $2.5 \mathrm{~mm}$. Bisexual utricles similar to unisexal ones, but more widely mouthed. Achenes $3.5-4.3 \times 0.9-1.3 \mathrm{~mm}$, ellipsoid-trigonous, yellowish-brown, tipped by a broadly pyramidal and shortly neck-like at the lower part, persistent style base.

\section{Distribution}


1424 Endemic to Eastern Cape and KwaZulu-Natal provinces (South Africa). [27 CPP NAT]. Fig.

$142515 \mathrm{C}$.

1426

1427

1428

\section{Habitat}

1429

Shady places, mainly in margins and clearing of forests, close to the coast (Indian Ocean Coastal

1430

1431

Belt Biome: Pondoland-Ugu Sandston Coastal Sourveld); 200-400 m.

1432 The epithet honours Professor Kathleen D. Gordon-Gray (1918-2012), a South African Botanist, 1433 as homage to her excellent works in KwaZulu-Natal Cyperaceae, especially in the former genus 1434 Schoenoxiphium. In the holotype she noted: "This may possibly be an unusual specimen of Sch. 1435 lehmannii (Nees) Steudel, but the much wider leaves and longer utricles $(7 \mathrm{~mm})$ make this 1436 doubtful ... Field investigation needed".

1437

1438

1439

Iconography

1440

1441 Conservation

Figs. 19 and 20.

1442 Not Evaluated (NE).

1443

1444

1445

1446

1447

1448

1449

1450

Carex killickii Nelmes, Kew Bull. 10: 89, 1955.

1451

1452 = Schoenoxiphium filiforme Kük., Bull. Misc. Inform. Kew 1910: 129; non Carex filiformis L. 1453 (1753).

1454 Type: South Africa. Cape Colony: Summit of Great Winterberg, under rocks, 2570 m., 8-III-

1455 1900, Galpin 5605 (lectotype: K-000693800 digital image!, designated by Kukkonen (1983);

1456 iso-: PRE-0107826 digital image!, GRA-0000244 digital image!).

1457

1458 = Schoenoxiphium molle Kukkonen, Notes Roy. Bot.Gard. Edinburgh 43: 366, 1986. Type:

1459 South Africa. KwaZulu-Natal, Underberg district, 5 - 7 miles NNW of Castle View Farm,

1460 headwaters of Mlahlangubo River. c. 7000', 23-XI-1980, Hilliard \& Burtt 13574 (holotype: H-

14611455011 digital image!; iso-: E-00286097 digital image!, GENT-0000090032813 digital image!, 1462 NU-0015652 digital image!). 
1464 = Schoenoxiphium strictum Kukkonen, Notes Roy.Bot. Gard. Edinburgh 43: 366, 1986. Type:

1465 South Africa. KwaZulu-Natal, Underberg district, Garden Castle Forest Reserve, Mlambonja 1466 Valley. 6800', 05.01.1982, Hilliard \& Burtt 14909 (holotype: H-1461500 digital image!; iso-: E14670286107 digital image!, GENT-0000090032929 digital image!, NU-0015651 digital image!).

1468

1469

1470

1471

1472

1473

1474

1475

1476

1477

1478

1479

1480

1481

1482

1483

1484

1485

1486

1487

1488

1489

1490

1491

1492

1493

1494

1495

1496

1497

1498

1499

1500

1501

1502

1503

Rhizome loosely to densely caespitose, with short internodes, slender, brown. Flowering culms (8.5)15-50(95) cm long, acutely trigonous, smooth or, more rarely, somewhat aculeate at the apex, leafy usually up to half (upper third) of its length, 0.3-0.9(1.5) mm wide at the middle. Leaves $0.2-1(3.6) \mathrm{mm}$ wide, shorter to longer than the inflorescence, soft to somewhat rigid, light green, canaliculate to involute more rarely flat in cross-section, more or less scabrous along the edges; abaxial surface smooth or scabrid in the midrib; adaxial surface smooth; somewhat curved or scarcely curled at the apex; ligule $0.3-1.2 \mathrm{~mm}$ long. Basal sheaths usually not or scarcely fibrous, more rarely very fibrous, with lamina. Lowest bract of the inflorescence usually glumaceous with setaceous apex or, more rarely, leaf-like, shorter to longer than the inflorescence, not sheathing except when the lowest partial inflorescence is long-pedunculate and clearly separate from the remaining ones, in this case sheath up to $25(40) \mathrm{mm}$ long. Inflorescence reduced to a terminal, androgynous spike or branching up to 3 times; partial inflorescences 15(7), overlapping and sessile or, more rarely, the lowest one clearly distant and longpedunculate, patent, erect-patent or somewhat reflexed except the lowest one distant and pedunculate that is suberect when present. Glumiform perigynia and glumiform cladoprophylls absent. Tubular cladoprophylls absent or hyaline when the lowest partial inflorescence is distant and long-pedunculate. Utriculiform cladoprophylls present except in unispicate inflorescences. Male glumes (3)3.5-4.2(4.5) $\times(0.9) 1.2-1.5(1.7) \mathrm{mm}$, ovate-lanceolate, obovate or elliptical, brown with a green central band, acute to acuminate, frequently ending in an arista up to $0.8 \mathrm{~mm}$. Female glumes 3.1-4.2 $\times 1.2-2 \mathrm{~mm}$, lanceolate to ovate, pale to dark brown with a green central band, acute, acuminate to aristate, sometimes with a scabrid acumen up to $1.8 \mathrm{~mm}$. Unisexual utricles 3.8-5.3(7.2) $\times 0.5-1.2 \mathrm{~mm}$, narrowly linear-oblongoid to narrowly elipsoid, distinctly stipitate, usually straight, more rarely slightly arcuate, straw-coloured to yellowish-brown when mature, smooth to dispersely and shortly hispid in the upper half, with few to numerous faintly to strongly prominent veins across the entire surface, patent at the maturity, gradually attenuated into a more or less irregular beak up to $1 \mathrm{~mm}$; rachilla reaching or protruding a little from the apex of the utricle or, more rarely, much protruding from the mouth and bearing some small, sterile glumes at the top. Bisexual utricles wide and asymmetrically truncate. Achenes (2.)2.5$3.2(3.6) \times 0.4-1 \mathrm{~mm}$, oblong-trigonous, yellowish to pale-brown, tipped by a short, obtusely trigonous to long-pyramidal, persistent style base.

\section{Distribution}

Endemic to the Drakensberg Mountains with isolated localities in Eastern Cape and southeastern KwaZulu-Natal. Lesotho (Butha Buthe, Leribe, Maseru Qacha's Nek and Thaba Tseka districts) 
1504 and South Africa (Eastern Cape, Free State, KwaZulu-Natal and Western Cape). [27 CPP LES

1505 NAT OFS]. Fig. 15D.

1506

1507 Habitat

1508 Open, stony and mesophilous to damp meadows, bogs, and shrubland, usually at high altitudes

1509 (Grassland Biome: Drakensberg Grassland; Indian Ocean Coastal Belt Biome: KwaZulu Natal

1510 Coast Belt); (550)1650-3150 m.

1511

1512 Etymology

1513 Named after Donald Joseph Boomer Killick (1926-2008), South African botanist specialized in 1514 Drakensberg flora, who collected the type material of this species.

1515

1516 Iconography

1517 Figs. $17 \mathrm{C}$ and 21.

1518

1519 Conservation

1520 Not considered of conservation concern at the national level in South Africa, and thus

1521 categorized as Least Concern (LC) (see SANBI, 2020, sub Schoenoxipium molle; sub $S$.

1522 filiforme).

1523

1524

1525

1526

1527

1528

1529

1530

1531

1532

1533

1534

1535

1536

1537

1538

1539

1540

1541

Notes

This species is the most morphologically variable in the section, in particular its inflorescence structure. This has caused taxonomic delimitation problems between this species and close ones (e.g. the former Schoenoxiphum molle and S. strictum; see Gordon-Gray, 1995; SANBI, 2020). The common forms of $C$. killickii present fertile culms of 20-50(60) cm, canaliculate to involute, filiform leaves, unispicate or branched inflorescences and narrowly ellipsoid, smooth or slightly scabrid, utricles up to $5.3 \times 0.9-1.2 \mathrm{~mm}$ long, with numerous prominent veins. Nevertheless, the specimens that inhabits summits of the Drakensberg mountains are shorter $(8.5-30 \mathrm{~cm})$, with unispicate inflorescences and unisexual utricles narrowly linear, smooth or rarely slightly scabrid, 5-7.2 $\times 0.5-0.8 \mathrm{~mm}$, mostly without numerous veins and, however noticeable, hardly prominent. This form corresponds to the C. killickiii Nelmes type material, described from the mountain summits of Lesotho. Moreover, transition morphotypes towards the more common forms appear in lower altitudes from those mountains. Regarding the type material of Schoenoxiphium filiforme Kük. (1910), described from the Great Winterberg Mountain range (Eastern Cape, north of Adelaide), it shows unispicate inflorescences and fertile culms of 20-25 $\mathrm{cm}$, but the utricles are more similar to the common forms. Additionally, as it is shown in the phylogeny of Figure S2, the sample from the Lesotho summits is nested within more typical 1542 forms of the species (unispicate or with branched inflorescences). However, given the molecular variability of this taxon and the fact that a single sample from the summit form was included in 
1543 the RAD phylogeny, we cannot rule out that the summit morphotype corresponds to a different 1544 taxon. That can only be resolved by carrying out a phylogeographic study of the species.

1545 Moreover, densely caespitose forms inhabit the lower slopes of the Drakensberg (1800-2300 m), 1546 forming tussocks with fertile culms up to $70(95) \mathrm{cm}$, flat or slightly canaliculate leaves up to 1547 2.5(3.6) $\mathrm{mm}$ width that surpass the culms length, inflorescences always branched and utricles 1548 sparsely hispid towards the apex or hispid just in the lower half. This morphotype corresponds to 1549 the material described as Schoenoxiphium molle Kukkonen (1983). Likewise, in areas with 1550 similar habitats appear forms with smooth culms and less wider leaves, flat or canaliculate, that 1551 have been described as $S$. strictum Kukkonen. Between these two and the typical forms of the 1552 species, a multitude of intermediates phenotypes can be found, so we consider that, until further 1553 phylogeographic studies, these forms should be included under the wide morphological 1554 variability of $C$. killickii.

1555 Finally, since the population from Oribi gorge (Port Shepstone distr., KwaZulu-Natal, L.E. 1556 Davidson 2648 (NU)) grows in remarkably low altitude (ca. $550 \mathrm{~m}$ ), with respect to the 1557 remaining populations of the species, it would be interesting to further study this population.

1558

1559 Selected reference

1560 Gordon-Gray (1995).

1561

1562

1563 Carex kukkoneniana Luceño \& Martín-Bravo, Bot. J. Linn. Soc. 179: 27, 2015.

1564

1565 Type: [South Africa] Natal [KwaZulu-Natal], IV-1884, G. Buchanan 134 (holotype: K1566000693792 digital image!).

1567

1568

इ Carex buchananii C.B.Clarke in Harvey \& auct. suc. (eds.), Fl. Cap. 7: 305. 1898, nom. illeg.; 1569 non Carex buchananii Berggr. (1880).

1570 इSchoenoxiphium buchananii C.B.Clarke ex Kük. in Engler (ed.), Pflanzenr. 38(IV, 20): 31 1571 (1909).

1572 三 Kobresia buchananii (C.B.Clarke) T.Koyama, J. Fac. Sci. Univ. Tokyo, Sect. 3, Bot. 8: 80. 15731961.

1574

1575 Rhizome caespitose, stout, with short internodes, dark-brown. Flowering culms (77)100$1576180(200) \mathrm{cm}$ long, erect, obtusely trigonous, smooth, leafy up to the half of its length, (2.6)31577 3.7(4) $\mathrm{mm}$ wide at the middle. Leaves (4.1)5.5-9.6(12.8) $\mathrm{mm}$ wide, shorter than the 1578 inflorescence, moderately rigid, glaucous, flat in cross-section, scabrous on the margins, mainly 1579 in the uppermost parts, and sometimes also along the abaxial midrib; adaxial surface smooth 1580 except at the apical part; straight at the apex; ligule 4-17 mm long. Basal sheaths entire to 1581 scarcely fibrous, usually with lamina. Lowest bract leaf-like, shorter than the inflorescence, with 1582 a sheath (20)29-63(80) mm long. Inflorescence c. $1 / 4$ of the length of the culm, branching up to 4 
1583 times; partial inflorescences (4)6-9(11), the 2-4 lowest long-pedunculate and more or less 1584 distant, the upper sessile to shortly pedunculate and overlapping. Glumiform perigynia and 1585 glumiform cladoprophylls absent. Tubular cladoprophylls always present, hyaline to brownish. 1586 Utriculiform cladoprophylls always present. Male glumes (1.9)2.2-3.6(4.2) $\times 1.4-2.1 \mathrm{~mm}$, ovate, 1587 elliptic or obovate, yellowish-brown to dark brown, with a green central band, usually 1588 mucronate, with an aculeate mucro up to $0.6 \mathrm{~mm}$ long. Female glumes (2.7)3.1-3.8(4.4) $\times 1.5-$ $15892.3(2.8) \mathrm{mm}$, ovate, yellowish-brown to brown, with a green central band, ending in an aculeate 1590 mucro up to 2(4) $\mathrm{mm}$. Unisexual utricles (3.7)5-6.8(7.6) $\times(0.8) 0.9-1.1(1.2) \mathrm{mm}$, linear to 1591 narrowly ellipsoid, long-stipitate, straight or, more rarely, arquate, straw-coloured to yellowish1592 brown when mature, more or less aculeate in the upper third, with numerous prominent veins 1593 across the entire surface, suberect to erecto-patent, gradually attenuate into a split in one side 1594 beak up to $1.5(1.9) \mathrm{mm}$; rachilla reaching to protruding from the apex of the utricle by up to 0.5 $\mathrm{mm}$, sometimes bearing 1-few small, sterile glumes at the top. Bisexual utricles with the apex wide and obliquely truncate. Achenes (2.9)3-3.9(4.1) $\times(0.6) 0.8-1.1 \mathrm{~mm}$, oblong, trigonous, straw-coloured to yellowish-brown when mature, tipped by a neck-like, more rarely subterete, persistent style base.

1599

1600

\section{Distribution}

Eastern Africa, from Tanzania to South Africa: Eswatini (Hhohho district), Malawi (Chitipa and 1602 Rumphi districts), South Africa (Eastern Cape, KwaZulu-Natal and Mpumalanga provinces), Tanzania (Iringa and Mbeya regions) and Zimbabwe (Manicaland province). [25 TAN 26 MLW 1604 ZIM 27 CPP NAT SWZ TVL]. Fig. 15E.

1605

1606

\section{Habitat}

1608

Edges of streams, marshy grounds and other damp soils in mountains (Grassland Biome:

1609 Drakensberg Grassland, Sub-Escarpment Grassland and Mesic Highveld Grassland); 950-2500

1610

1611 $\mathrm{m}$.

1612 Named after Dr. Toivo Ilkka Kalervo Kukkonen (1926-2020), Finnish botanist specialized in 1613 sedges, who worked in the former genus Schoenoxiphium and described several new species.

1614

1615

1616

Iconography

1617

1618

Fig. 22. Haines \& Lye (1983, sub Schoenoxiphium rufum).

1619 Not evaluated (NE).

1620

1621

1622 Carex lancea (Thunb.) Baill., Hist. Pl. 12: 341, 1894. 
1623

1624

1625

1626

1627

1628

1629

1630

1631

1632

1633

1634

1635

1636

1637

1638

1639

1640

1641

1642

1643

1644

1645

1646

1647

1648

1649

1650

1651

1652

1653

1654

1655

1656

1657

1658

1659

1660

1661

1662

Type. [South Africa] Cap. b. Spei, Thunberg s.n. (lectotype: UPS-1350 digital image!, designated by Kukkonen (1983)).

三 Schoenus lanceus Thunb., Prodr. P1. Cap.: 17, 1794 [basionym.]

三Schoenoxiphium capense Nees, Linnaea 7: 533. 1832.

三Schoenoxiphium lanceum (Thunb.) Kük. in Engler (ed.), Pflanzenr. 38(IV, 20): 28, 1909.

三 Kobresia lancea (Thunb.) Koyama, J. Fac. Sci. Univ. Tokyo, Sect. 3. Bot. 8: 80, 1961.

= Schoenoxiphium meyerianum Kunth, Enum. P1. 2: 530.1837.

Type: [South Africa] Cap. b. spei, Drège s.n. (lectotype: P-00461996 digital image! here designated; isolecto-: LE-00010148 digital image!).

= Schoenoxiphium sickmannianum Kunth, Enum. P1. 2: 530. 1837.

Type: [South Africa] Cape b. spei, Ecklon s.n. "Sickmann in herb. Lucae." Not found.

Rhizome caespitose with more or less short internodes, stout, dark-brown. Flowering culms (50)60-110(170) cm long, erect, acutely trigonous, smooth, leafy from lower half of its length, (1)1.5-2 mm wide at the middle. Leaves (3)4-8(8.8) mm wide, shorter than the inflorescence, moderately coriaceous, green, flat in cross-section, but with an adaxial groove in the midrib area and trigonous to the apex, very scabrous along the edges and also along the abaxial midrib; adaxial surface smooth; usually curved at the apex; ligule 0.7-1.5(2) mm long. Basal sheaths entire to scarcely fibrous, with lamina. Lowest bract of the inflorescence leaf-like, shorter than the inflorescence length, with a sheath $40-60 \mathrm{~mm}$ long. Inflorescence occupying between $1 / 3$ and

$1 / 2$ of the length of the culm, branching up to 4 times; partial inflorescences (8)11-14(16), the 3-7 lowest distant, pedunculate, nodding, with the part of the peduncle protruding from the sheath much shorter than the linear fertile part, the upper subsessile to shortly pedunculate and overlapping. Glumiform perigynia present, unisexual or bisexual. Glumiform cladoprophylls present. Tubular cladoprophylls present at the base of the distant partial inflorescences, hyaline. Utriculiform cladoprophylls absent. Male glumes 4.1-6.4(6.9) $\times(1.1) 1.5-(2.2) \mathrm{mm}$, ovatelanceolate to ovate, yellowish-brown to brown, with a green central band, acuminate, ending in an aculeate mucro or ariste up to $1 \mathrm{~mm}$ long. Female glumes 5-6.2 $\times 1.8-2.2 \mathrm{~mm}$, lanceolate to ovate, straw-coloured-brown to pale brown, with a green central band, acuminate, ending in an aculeate mucro up to $1(1.7) \mathrm{mm}$ long. Unisexual utricles $5.5-6.1 \times 0.7-1 \mathrm{~mm}$, narrowly linear to narrowly oblong, stipitate, straight, straw-coloured to pale brown when mature, smooth, more rarely scabrous in the upper tiers, with numerous prominent veins across the entire surface, suberect, gradually attenuate in a more or less split, more or less scabrous beak up to $1.7 \mathrm{~mm}$ length; rachilla reaching to protruding from the apex up to $0.6 \mathrm{~mm}$. Bisexual utricles absent. Achenes 3.5-4.5 × 0.6-1.2 mm, oblong-trigonous, pale to dark-brown when mature, tipped by a longly pyramidal, persistent style base.

Peer] reviewing PDF | (2021:02:57694:1:1:NEW 25 Mar 2021) 
1663

1664

1665

1666

1667

1668

1669

1670

1671

1672

1673

1674

1675

1676

1677

1678

1679

1680

1681

1682

1683

1684

1685

1686

1687

1688

1689

1690

1691

1692

1693

1694

1695

1696

1697

1698

1699

1700

1701

1702

\section{Distribution}

Endemic to Cape region, South Africa (Eastern and Western Cape provinces). [27 CPP]. Fig. $15 \mathrm{~F}$.

\section{Habitat}

Edges of streams and other damp and shady places in forest (Afrotemperate, Subtropical and Azonal Forests Biome: Southern Afrotemperate Forest; Fynbos Biome: Sandstone Fynbos;

Succulent Karoo Biome: Rainshadow Valley Karoo); 20-1500 m.

\section{Etymology}

From the latin lancea-ae, spear, probably because of the shape of its broadly linear leaves.

\section{Iconography}

Figs. 23 and 24A. Kükenthal (1909; sub Schoenoxiphium lanceum).

\section{Conservation}

Not considered of conservation concern at the national level in South Africa, and thus categorized as Least Concern (LC) (SANBI, 2020; sub Schoenoxiphium lanceum).

\section{Notes}

There are a number of potential syntypes of the name Schoenoxiphium meyerianum Kunth which do not fully match the lectotype label but could have been original material seen by Kunth (e.g. LE00010147 digital image!, P00461995 digital image!). Likewise, we have not been able to trace an adequate lectotype for the name Schoenoxiphium sickmannianum Kunth. A potential syntype ([South Africa, Cape Town, Mount Table] In umbrosis inter saxa altitud. 4 mont. tabul, C.F. Ecklon 851; HAL-0109862 digital image!, TUB007505 digital image!) which belongs to $C$. lancea is nonetheless cited by Kunth as doubtful.

Carex ludwigii (Hochst.) Luceño \& Martín-Bravo, Bot. J. Linn. Soc. 179: 27, 2015.

इ Schoenoxiphium ludwigii Hochst., Flora, 28: 764 (1845) [basionym].

Type: [South Africa] In Cap b. Spei, 1837, B. de Ludwig (lectotype: TUB-007504 digital image!, here designated; iso-: TUB-007503 digital image!, M-0110633 digital image!)

= Schoenoxiphium rufum Nees in Linnaea 10: 201 (1836).

Type: [South Africa] Ceded Territory, bei Phillipstown am Katrivier, 2000-3000', October, leg. Ecklon \& Zeyher site 33 (see Drège, 1847b: 586) (lectotype: S-10-1122, designated by Kukkonen (1983) digital image!, isolecto-: G-00195305 digital image!). 
1703 三 Carex rufa (Nees) Baill., Hist. Pl. 12: 340. 1894, nom. illeg.; non Lam. (1779).

$1704 \equiv$ Archaeocarex rufus (Nees) Fedde \& J.Schust., Just's Bot. Jahresber. 41(2): 7 (1913) (publ.

1705 1918).

$1706 \equiv$ Kobresia rufa (Nees) T.Koyama, J. Fac. Sci. Univ. Tokyo, Sect. 3, Bot. 8: 80 (1961).

1707

1708 =Schoenoxiphium dregeanum Kunth, Enum. Pl. 2: 529 (1837); non Carex dregeana Kunth

1709 (1837).

1710 Type: [South Africa] Cap-de-Bonne-Espérance. Stormberg, 17-XII-1832, 5000-6000 ped., Drège

$17117399 a$ (lectotype: P-00461997 digital image!, here designated; isolecto-: P00540803 digital

1712 image!). Syntypes: Afrique Australe, Wynberg, 5-V-1856, Drège 7399c, P-00461998 digital

1713 image!; Cap b. sp., Drège s.n., LE-00010146 digital image!.

1714 इSchoenoxiphium rufum var. dregeanum (Kunth) Kük., in Engler (ed.), Pflanzenr. 38(IV, 20):

171530 (1909).

1716

1717 = Schoenoxiphium rufum var. pondoense Kük. in Engler (ed.), Pflanzenr. 38(IV, 20): 31 (1909).

1718 Type. [South Africa] Pondoland, Bachmann n. 116. Not seen, originally probably at B, likely

1719 destroyed.

1720

1721

Rhizome more or less caespitose, with short or somewhat elongated internodes, stout, medium to

1722

1723

1724

1725

1726

1727

1728

1729

1730

1731

1732

1733

1734

1735

1736

1737

1738

1739 dark-brown. Flowering culms (34)65-110(115) cm long, erect, obtusely trigonous, smooth, leafy up to the half of its length, (1.1)1.8-2.3(2.5) mm wide at the middle. Leaves (2.4)4.5-7.5(9.4) $\mathrm{mm}$ wide, shorter than the inflorescence, moderately rigid, more or less glaucous, flat to slightly $\mathrm{V}$-shaped in cross-section, scabrous on the margins, except at the base, and along the abaxial midrib; adaxial surface scabrid at the apical parts; straight to curved at the apex; ligule (1)3$6(9.5) \mathrm{mm}$ long. Basal sheaths with lamina or, more rarely, 1-few lowermost bladeless, entire or, more rarely, somewhat fibrous. Lowest bract of the inflorescence leaf-like, shorter than the inflorescence, rarely equaling it, with a sheath (20)29-59(66) $\mathrm{mm}$ long. Inflorescence up to the upper $1 / 3(2 / 3)$ of the length of the culm, branching up to 4 times; partial inflorescences (5)8-14, (2)4-5(6) lowermost distant, usually the 1(2) lowermost nodding. Glumiform perigynia and glumiform cladoprophylls absent, except for the occasional presence of some bisexual, glumiform perigynium. Tubular cladoprophylls always present. Utriculiform cladoprophylls usually present. Male glumes (2)2.2-4(4.5) $\times(0.6) 1.3-2.5(2.9) \mathrm{mm}$, ovate, yellowish-brown to brown, with a green central band, ending in an aculeate mucro up to 1(1.6) $\mathrm{mm}$ long. Female glumes (1.7)2.3-3(4) × 1.7-2.1(3) mm, widely ovate to suborbicular, yellowish-brown to brown, with a green central band, ending in an aculeate mucro up to 2.5(2.9) $\mathrm{mm}$ long. Unisexual utricles $(2.6) 2.8-3.7(4.9) \times 1.2-1.6(1.7) \mathrm{mm}$, broadly ovoid, stipitate, slightly to, more

1740 frequently, strongly curved, rarely straight, straw-coloured to brownish when mature, usually hispid in the upper third, with conspicuous prominent veins over the entire surface, suberect to erecto-patent, abruptly contracted into a bidentate, truncate to one-side shortly split beak $0.5-1.2$

1742 $\mathrm{mm}$ long; rachilla reaching to, rarely, protruding from the apex of the utricle by up to $0.5 \mathrm{~mm}$. 
1743 Bisexual utricles similar in shape to the unisexual ones, but with the apex widely and obliquely

1744 truncate or, less frequently, open almost to the base. Achenes 2-2.4(3.1) $\times(1) 1.2-1.5(1.9) \mathrm{mm}$,

1745 ovate-trigonous, sometimes with a deep, transverse groove in one side, straw-coloured to

1746 yellowish-brown when mature, tipped by a short, neck-like, more rarely subterete-trigonous,

1747 frequently asymmetric, persistent style base.

1748

1749

\section{Distribution}

1750 Endemic to Lesotho (Berea, Leribe and Maseru districts) and South Africa (Eastern Cape, Free 1751 State, KwaZulu-Natal, Mpumalanga and Western Cape provinces). [27 CPP LES NAT OFS 1752 TVL]. Fig. 15G.

1753

1754

\section{Habitat}

1755

Edges of streams and other damp places in mountains (Grassland Biome: Drakensberg

1756

Grassland, Mesic Highveld Grassland and Subscarpment Grassland); 1350-2850 m.

1757

1758

1759

\section{Etymology}

1760

Named after Carl Ferdinand Heinrich von Ludwig (Baron von Ludwig) (1784-1847), German

1761

1762 pharmacist, naturalist and businessman who started Cape Town's first botanic garden.

1763

\section{Iconography}

1764

1765

Figs. 24B and 25.

1766

\section{Conservation}

1767

The species has been evaluated as Least Concern (LC) at global level (IUCN, 2018). However, this was based on a distribution range that may likely include populations belonging to other

1768 species (C. kukkoneniana). It has also been evaluated as LC at the national level in South Africa

1769 (SANBI, 2020; sub Schoenoxiphium rufum).

1770

1771

Notes

1772 When this species and C. bolusii C.B. Clarke are sympatric, it is possible to observe individuals showing intermediate morphological features between both taxa, probably due to hybridization.

1774 References to this species for the countries placed north of South Africa (see Kukkonen, 1983)

1775 belong to $C$. kukkoneniana.

1776 There is a number of additional potential syntypes of Schoenoxiphium dregeanum Kunth that bear a handwritten label by this author, but whose indications (sometimes lacking any) are not a perfect match to the protologue (e.g. HAL-0109860 digital image!, LE-0010145 digital image!, S-08-6967 digital image!, TUB-007502 digital image!).

Carex multispiculata Luceño \& Martín-Bravo, Bot. J. Linn. Soc. 179: 28, 2015. 
1783

1784

1785

1786

1787

1788

1789

1790

1791

1792

1793

1794

1795

1796

1797

1798

1799

1800

1801

1802

1803

1804

1805

1806

1807

1808

1809

1810

1811

1812

1813

1814

1815

1816

1817

1818

1819

1820

1821

1822

= Schoenoxiphium madagascariense Cherm., Bull. Soc. Bot. France 70: 299. 1923; non Carex madagascariensis Boeckeler (1884).

Type: Madagascar. Mont Tsaratanana, dans les bruyères, 2700 m., XII-1912, Perrier de la Bâthie 2501 (lectotype: P-s.n. digital image!, here designated, isolecto- P-00540579!, see notes below).

Rhizome not caespitose, with long internodes, stout, dark-brown. Flowering culms (25)40$80(90) \mathrm{cm}$ long, erect, acutely trigonous, smooth, leafy $2 / 3-4 / 5$ of its length, (1.5)2-2.8(3.5) mm wide at the middle. Leaves (2.1)6.5-10(11) mm wide, longer than the inflorescence, rarely shorter, coriaceous, more or less glaucous, flat, slightly carinate or somewhat canaliculate in cross-section, scabrous along the edges and usually along the abaxial midrib; adaxial surface smooth or sparsely aculeate on the midrib in the upper third of its length; straight at the apex; ligule $0.1-0.4 \mathrm{~mm}$ long. Basal sheaths entire, with lamina or, rarely, the lowermost bladeless. Lowest bract of the inflorescence leaf-like, longer than the inflorescence length, rarely shorter, not sheathing or the lowermost with a sheath up to $40 \mathrm{~mm}$ long. Inflorescence branching up to 3(4) times, very dense, rarely somewhat lax, multispiculate, broadly ovoid to suborbicular, occupying up to the upper $1 / 5$ of the of the culm, rarely up to $1 / 3$, but then composed by $2-3$ three suberect to erect, ovoid to suborbicular parts, one terminal and 1-2 lateral, long-pedunculate, distant parts; partial inflorescences (9)11-21(25), erect, subsessile, overlapping, or the 1-2 lowermost long-pedunculate and distant. Glumiform perigynia and glumiform cladoprophylls occasionally present. Tubular cladoprophylls always present at the base of the peduncles of the lowermost partial inflorescences, hyaline to brownish. Utriculiform cladoprophylls always present. Male glumes 3-6 × (1)1.5-2 mm, ovate-lanceolate to ovate, yellowish-brown to brown, with a green central band, usually with an aculeate mucro or arista up to $1(1.5) \mathrm{mm}$ long. Female glumes 3-6.5 × 1.8-2.3 mm, ovate, predominantly brownish, with a green central band, ending in an aculeate mucro up to 2(6) mm long. Unisexual utricles, when present, 4.4-6.5 $\times 0.6-0.8$ $\mathrm{mm}$, narrowly linear, straw-coloured, yellowish-brown to subhyaline when mature, stipitate, straight to arcuate, smooth, with numerous prominent veins across the entire surface, suberect to erecto-patent, gradually attenuated into an obliquely truncate, irregular to slightly bifid beak up to 2(2.5) mm length; rachilla protruding from the apex up to 5(8) $\mathrm{mm}$ long. Bisexual utricles widely and obliquely truncate and more or less split at the apex. Achenes $3-5.5 \times 0.5-0.7 \mathrm{~mm}$, oblong-trigonous, yellowish-brown when mature, tipped by a shortly trigonous to pyramidal, persistent style base.

\section{Distribution}

Eswatini (Hhohho district), Madagascar (Tsratanana mountains) and South Africa (KwaZuluNatal, Free State and Mpumalanga provinces). [27 NAT OFS TVL SWZ 29 MDG]. Fig. 26A.

\section{Habitat}

Peer] reviewing PDF | (2021:02:57694:1:1:NEW 25 Mar 2021) 
1823 Edges of streamsand waterfalls, damp meadows, and other damp places in mountains (Grassland 1824 Biome, Drakensberg Grassland, Mesic Highveld Grassland and Subscarpment Grassland); 1100 $18252800 \mathrm{~m}$.

1826

1827 Etymology

1828 From the Latin multus-a-um, many, and spicula-ae, spikelet, because of its very branched 1829 inflorescence which is composed of numerous spikelets.

1830

1831 Iconography

1832 Figs. 24C and 27.

1833

1834

Conservation

1835

1836

Not considered of conservation concern at the national level in South Africa, and thus

1837 categorized as Least Concern (LC) (SANBI, 2020, 2005; sub Schoenoxiphium

1838

1839 madagascariense).

\section{Notes}

1841

Two vouchers are kept in P with the number 2501 of Perrier de la Bâthie, one of them (P-s.n.)

1842 contains a complete and typical specimen of the species including two fertile culms, while the other (P-00540579) includes a less typical individual with just a fertile culm, so we have designated as a lectotype the first of them.

Carex perdensa (Kukkonen) Luceño \& Martín-Bravo, Bot. J. Linn. Soc. 179: 28, 2015.

इSchoenoxiphium perdensum Kukkonen, Bot. Not. 131: 265. 1978 [basionym]. Type: South Africa. [Eastern] Cape Prov., Distr. King William's Town, Keiskama Hoek, near Ghulu Kop, 4000', XII-1925, R.A. Dyer 245a (holotype: K-000693793 digital image!; iso-: K000693794 digital image!, PRE-0106552 digital image!).

Rhizome densely caespitose, with very short internodes, slender, dark-brown. Flowering culms $7.5-15(25) \mathrm{cm}$ long, obtusely trigonous, smooth, leafy only at base, $0.4-0.5(0.7) \mathrm{mm}$ wide at the middle. Leaves (0.2)0.3-0.5(1.5) $\mathrm{mm}$ wide, shorter or longer than the inflorescence, scarcely rigid, green to slightly glaucous, involute or canaliculate, scabrous along the edges and the upper part of the abaxial midrib; adaxial surface smooth to somewhat scabrous to the apical part; ligule $0.3-1 \mathrm{~mm}$ long. Basal sheaths entire to scarcely fibrous, lowermost bladeless, uppermost with lamina. Lowest bract leaf-like, usually longer than the inflorescence, more rarely shorter, with a sheath $7-12 \mathrm{~mm}$ long. Inflorescence up to $3 / 4$ of the length of the culm, branching up to 2 times; partial inflorescences (2)3-4(5), very lax, bearing up to 2(3) female flowers, erect, distant, 
1863 present at the base of partial inflorescences, hyaline; utriculiform cladoprophylls absent. Male

1864

1865

1866

1867

1868

1869

1870

1871

1872

1873

1874

1875

1876

1877

1878

1879

1880

1881

1882

1883

1884

1885

1886

1887

1888

1889

1890

1891

1892

1893

1894

1895

1896

1897

1898

1899

1900

1901

1902

glumes 2-3.2(3.6) $\times 1.2-1.5 \mathrm{~mm}$, lanceolate to ovate, yellowish-brown, with a green central

band, ending in an aculeate mucro up to $1.2 \mathrm{~mm}$ long. Female glumes (1.9)2.2-2.8(3.5) $\times 1.5-2$

$\mathrm{mm}$, widely ovate to suborbicular, predominantly yellowish-brown, with a green central band, ending in an aculeate mucro up to $1.2(2.8) \mathrm{mm}$. Unisexual utricles $2.6-3.6 \times 1.4-1.9 \mathrm{~mm}$, widely ovoid to widely ellipsoid, stipitate, straight to weakly curved, straw-coloured to yellowish-brown when mature, with numerous, more or less prominent veins across the entire surface, erect to erecto-patent, abruptly contracted into a smooth, bidentate to irregular beak $0.5-1 \mathrm{~mm}$ long; rachilla reaching the apex to protruding from it up to $0.7 \mathrm{~mm}$. Bisexual utricles absent. Achenes $1.8-2.8 \times 1-1.4 \mathrm{~mm}$, widely ellipsoid-trigonous, straw-coloured to dark-brown when mature, tipped by a short obtusely trigonous, asymmetric, persistent style base.

\section{Distribution}

Endemic to South Africa (Eastern Cape and KwaZulu-Natal provinces). [27 CPP NAT]. Fig. 26B.

\section{Habitat}

Grassland (Grassland Biome: Drakensberg Grassland); 1200-1950 m.

\section{Etymology}

From the Latin prefix per, very, and adjective densus-a-um, dense, because of the densely caespitose habit of this plant.

\section{Iconography}

Figs. 28 and 29A. Kukkonen (1978).

\section{Conservation}

Not considered of conservation concern at the national level in South Africa, and thus categorized as Least Concern (LC) (SANBI, 2020; sub Schoenoxiphium perdensum).

Carex pseudorufa Luceño \& Martín-Bravo, Bot. J. Linn. Soc. 179: 28, 2015.

इ Schoenoxiphium burttii Kukkonen, Notes Roy. Bot. Gard. Edinburgh 43: 365. 1986; non Carex burttii Noltie (1993).

Type: South Africa. KwaZulu-Natal, Underberg distr., 2929 CB, Chameleon area, c. 5 miles N of Castle View farm, 6700ft, forming loose clumps at streamside, 2-XII-1984, Hilliard \& Burtt 17812 (lectotype: E-00200232 digital image! here designated (see notes); isolecto-: GENT0000090032820 digital image!, GENT-0000090032844 digital image!, GENT-0000090032943 digital image!, NU-0015687 digital image!). 
1903

1904

1905

1906

1907

1908

1909

1910

1911

1912

1913

1914

1915

1916

1917

1918

1919

1920

1921

1922

1923

1924

1925

1926

1927

1928

1929

1930

1931

1932

1933

1934

1935

1936

1937

1938

1939

1940

1941

1942
Rhizome caespitose, with short internodes, very stout, pale-brown to dark-brown. Flowering culms (55)72-111(118) cm long, obtusely trigonous, smooth, leafy up to half of its length, (2.3)2.5-4.3(5) mm wide at the middle. Leaves (5.5)8.3-13.9(17) mm wide, shorter than the inflorescence, moderately rigid, straight at the apex, light green, flat in cross-section, slightly scabrous along the margins and usually along the upper half of the abaxial midrib; adaxial surface usually finely papillose near de margins; ligule (1)3-6(8) mm long. Basal sheaths with lamina, entire or, rarely, the lowermost somewhat fibrous. Lowest bract of the inflorescence leaflike, from half of the inflorescence length to, more rarely, equaling it, with a sheath (37)39-69 $\mathrm{mm}$ long. Inflorescence up to the upper $3 / 4$ of the length of the culm, branching up to 4 times; partial inflorescences 7-13, very dense, ovoid to ellipsoid, the (3)4-6 lowermost distant and nodding, the uppermost overlapping, nodding to suberect. Glumiform perigynia and glumiform cladoprophylls absent. Tubular cladoprophylls always present; utriculiform cladoprophylls absent. Male glumes (2.8)3.3-4.7(5.3) × (1)1.4-1.9(2.2) mm, ovate-lanceolate to ovate, brown to reddish brown, with a green central band, ending in an aculeate mucro up to $0.8 \mathrm{~mm}$ long. Female glumes $(2.7) 3-4.5(5.5) \times 1.7-2.7(3,8) \mathrm{mm}$, widely ovate to suborbicular, brown to reddish brown, with a green central band, ending in a prominent aculeate mucro up to $1.1 \mathrm{~mm}$ long. Unisexual utricles (5.3)6.5-8(8.4) × (1.1)1.3-1.7(1.8) mm, linear, lancolate or narrowly ellipsoid, stipitate, straight to slightly arcuate, straw-coloured to reddish brown, sometimes redspotted when mature, dispersely aculeate to hispid in the upper third, with conspicuous prominent veins over the entire surface, suberect to erecto-patent, gradually attenuate, rarely somewhat contracted, into an asymmetrically bidentate to bifid or irregular beak 1.3-3.2 mm long; rachilla usually reaching the apex of the utricle, rarely protruding from it up to $0.5 \mathrm{~mm}$. Bisexual utricles usually present, widely and obliquely truncate at the apex. Achenes (3.6)3.7$4.6(4.9) \times(0.9) 1.1-1.4(1.5) \mathrm{mm}$, more or less oblong-trigonous, straw-coloured to yellowishbrown when mature, tipped by a very short, obtusely trigonous, frequently somewhat asymmetric, persistent style base.

\section{Distribution}

Endemic to the eastern slopes of the Drakensberg range in KwaZulu-Natal (South Africa). [27 NAT]. Fig. 26C.

\section{Habitat}

Edges of streams and wet meadows (Grassland Biome: Drakensberg Grassland); 1850-3200 m.

\section{Etymology}

From the Greek $\psi \varepsilon v \delta$ '́ (pseudo, resembling but not equalling) and the Latin rufus-a-um (red), alluding to the resemblance of this species to Carex ludwigii, which was formerly known as Schoenoxiphium rufum. 


\section{Iconography}

1944 Figs. 29B and 30.

1945

1946 Conservation

1947 Considered as Least Concern (LC) at the national level in South Africa (SANBI, 2020; sub

1948 Schoenoxiphium burttii).

1949

1950

Notes

1951

Kukkonen (1986) indicated that the holotype of S. burttii was at H, but a thorough search in this

1952 herbarium (H. Väre, pers.com.) has revealed that the specimen is lost, so the isotype at $\mathrm{E}$ is

1953 selected as the lectotype.

1954

1955

1956

Carex schweickerdtii (Merxm. \& Podlech) Luceño \& Martín Bravo, Bot. J. Linn. Soc. 179: 28, 1957 2015.

1958

三 Schoenoxiphium schweickerdtii Merxm. \& Podlech, Mitt. Bot. Staatssamml. München 3: 529, 1960 1960 [basionym].

1961 Type: South Africa. Drakensberge-Mariepskop, Gipfelfluren, 2000 m, 5-XII-1957, Merxmüller 1962 1963 590 (holotype: M-0110634 digital image!; iso-: PRE-0107827 digital image!).

1965

Rhizome caespitose, with very short internodes, stout, pale-brown to dark-brown. Flowering culms (25)30-90(130) cm long, erect, acutely trigonous, smooth or, rarely, very dispersely aculeate to the apex, leafy up $1 / 3(2 / 3)$ of its length, 2-3(3.8) $\mathrm{mm}$ wide at the middle. Leaves (4.7)6.5-11.5(18) mm wide, shorter than the inflorescence, more rarely longer, quite rigid, light green, plicate in cross-section, scabrous along the edges and usually also along the abaxial midrib; adaxial surface smooth to scabrid on the keels at the apex; straight at the apex; ligule up to $2 \mathrm{~mm}$ long. Basal sheaths with lamina or the lowermost bladeless, entire to somewhat fibrous. Lowest bract of the inflorescence leaf-like, longer than the inflorescence, with a sheath (18)2040(84) $\mathrm{mm}$ long, distichous and hiding the inflorescence when young. Partial inflorescences 610(14), erect, branching up to 3(4) times, lowermost pedunculate and more or less distant, and uppermost subsessile. Glumiform perigynia usually absent. Glumiform cladoprophylls present at the base of the second order branches. Tubular cladoprophylls always present at the base of the lower partial inflorescences, sometimes split almost to the base. Utriculiform cladoprophylls rare, more or less split. Male glumes (4)5-7 × (1)1.7-3 mm, ovate-lanceolate to elliptic, yellowish-brown to brown, with a green central band, acute or, more frequently, ending in an aculeate mucro or arista up to $0.7 \mathrm{~mm}$ long. Female glumes (5)6.5-8.6(9) $\times(1.5) 2-2.5(3) \mathrm{mm}$, lanceolate, ovate or elliptic, brown to yellowish, with a green central band, ending in a smooth to slightly aculeate mucro up to 2(3.6) mm long. Unisexual utricles (6)7-9.5(10) $\times 0.9-1.1 \mathrm{~mm}$, narrowly linear, straw-coloured to brownish when mature, stipitate, straight, smooth, with 
1983 numerous prominent veins across the entire surface, erect, gradually attenuated into an irregular

1984

1985

1986

1987

1988

1989

1990

1991

1992

1993

1994

1995

1996

1997

1998

1999

2000

2001

2002

2003

2004

2005

2006

2007

2008

2009

2010

2011

2012

2013

2014

2015

2016

2017

2018

2019

2020

2021

2022

beak up to $3 \mathrm{~mm}$ length, rarely split almost to base (glumiform perigynium); rachilla usually protruding from the apex up to $1(1.5) \mathrm{mm}$. Bisexual utricles widely and obliquely truncate at the apex. Achenes (4.2)4.8-6.1 $\times 0.8-1 \mathrm{~mm}$, oblong-trigonous, straw-coloured to dark brown when mature, tipped by a pyramidal, persistent style base.

\section{Distribution}

Lesotho (Butha Buthe district), South Africa (Eastern Cape, KwaZulu-Natal and Mpumalanga provinces), and Zimbabwe (Manicaland province). [26 ZIM 27 CPP LES NAT TVL]. Fig. 26D.

\section{Habitat}

Stony meadows and, more rarely, edges of streams and pools in mountains (Grassland Biome:

Drakensberg Grassland and Mesic Highveld Grassland); 1400-3100 m.

\section{Etymology}

Named after Herold Georg Wilhelm Johannes Schweickerdt (1903-1977), German botanist, who collected an important number of plants in South Africa, mainly in Mpumalanga and KwaZuluNatal, but also in Mozambique and Zimbabwe. The herbarium of the Pretoria University (PRU) was named in his honour.

\section{Iconography}

Figs. 31 and 32A.

\section{Conservation}

Not considered of conservation concern at the national level in South Africa, and thus categorized as Least Concern (LC) (SANBI, 2020; sub Schoenoxiphium schweickerdtii).

Carex sciocapensis Luceño, Márquez-Corro \& Sánchez-Villegas, nom. nov.

इSchoenoxiphium altum Kukkonen, Notes Roy. Bot. Gard. Edinburgh 43: 365. 1986; non C. alta Boott. (1845).

Type: South Africa. Cape, George div., Saalsveld, Groeneweidebos, 300 m, 02-III-1982, Geldenhuys 622 (lectotype: PRE-0812903-0 digital image!, here designated, see notes).

Rhizome not or laxly caespitose, with long internodes, moderately stout, medium to dark-brown. Flowering culms (25)37-68(96) cm long, obtusely trigonous, smooth, leafy usually up to the upper third of its length, (0.7)0.8-1.7(2.1) mm wide at the middle. Leaves (1)2.1-4.6(6) mm wide, shorter than the inflorescence, soft to scarcely rigid, light green to somewhat glaucous, flat in cross-section, finely papillose to slightly scabrous along the edges, and sometimes with a few 
2023 prickles along the abaxial midrib; adaxial surface smooth; straight to somewhat curved at the 2024 apex; ligule (1.1)1.6-3.8(6) mm long. Basal sheaths usually bladeless, not or slightly fibrous. 2025 Lowest bract of the inflorescence leaf-like, equaling or longer than the inflorescence length, not 2026 sheathing. Inflorescence oblong, rarely ovoid, branching up to three times; partial inflorescences 2027 (3)4-7, somewhat distant to overlapping, sessile. Glumiform perigynia and glumiform 2028 cladoprophylls absent. Tubular cladoprophylls always present, hyaline. Utriculiform 2029 cladoprophylls usually present in the lower and central parts of developed inflorescence. Male 2030 glumes (3.2)4.5-6.5(7.1) $\times(1.4) 1.6-2(2.2) \mathrm{mm}$, oblong-lanceolate to narrowly elliptical, light to 2031 yellowish-brown with a green central band, acute to shortly acuminate. Female glumes (3.9)4.2$20326.8(9.2) \times(1.7) 1.8-2.4(2.8) \mathrm{mm}$, ovate to elliptical, yellowish to dark brown with a green central 2033 2034 2035 2036

2037

2038

2039 2040

2041

2042

2043

2044

2045

2046

2047

2048

2049

2050

2051

2052

2053

2054

2055

2056

2057

2058

2059

2060

2061

2062 band, obtuse to acute. Unisexual utricles (6.1)6.4-8.9(10.1) $\times(0.7) 0.9-1.2(1.4) \mathrm{mm}$, linearoblong to very narrowly lanceolate in outline, long-stipitate, straight, straw-coloured to yellowish-brown when mature, smooth or very dispersely and shortly aculeate at the apex, with numerous prominent veins across the entire surface, suberect to patent, gradually attenuated into an obliquely trucate to slightly bifid beak up to $1.5 \mathrm{~mm}$; rachilla reaching the utricle or protruding from it by up to $6 \mathrm{~mm}$ or, more rarely, protruding from the mouth and bearing some small, sterile glumes at the top, but then, beak wide and obliquely truncate. Bisexual utricles widely and obliquely truncate at the apex. Achenes (3.9)4-5(5.4) $\times 0.7-1(1.1) \mathrm{mm}$, oblongtrigonous, light to dark brown when mature, tipped by a very short, obtusely trigonous, persistent style base.

\section{Distribution}

Endemic to Eastern and Western Cape provinces (South Africa). [27 CPP]. Fig. 26E.

\section{Habitat}

Shady places, mainly in margins and clearing of southern afrotemperate forest, but also in fynbos areas, especially on shale, dolerite and sandstone soils (Afrotemperate Forest Biome: Southern Afrotemperate Forest; Fynbos Biome: Sandstone Fynbos; and Succulent Karoo Biome: Rainshadow Valley Karoo); 10-1900 m.

\section{Etymology}

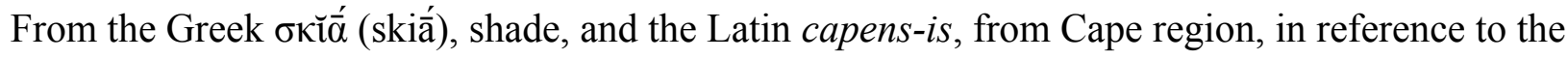
fact that it grows in shady areas of humid forests and its similarity to $C$. capensis.

\section{Iconography}

Figs. 32B and 33.

\section{Conservation}

It has been considered Near Threatened (NT) at the national level in South Africa due to its restricted range (with a substantial portion of its habitat lost in the recent past because of 
2063 exploitation of native forests and timber plantations) and competition with alien invasive plants 2064 (SANBI, 2020; sub Schoenoxiphium altum).

2065

2066 Notes

2067 This species is very closely related to C. capensis; in fact, both taxa are scarcely differentiated 2068 from a molecular point of view (see Phylogenetic section and Fig. 4); however, most individuals 2069 of both taxa are easily separated by its morphological features (see descriptions of both species). 2070 Nevertheless, specimens exhibiting intermediate morphology and ecology can be found, mainly 2071 in mountain areas, but also in Cape Peninsula, where some intermediate specimens and similar 2072 forms to C. sciocapensis inhabit in sunny places. Deeper systematic studies are needed to 2073 determine the existence of one or more cryptic species and to check if hybridization processes 2074 are taking place between these two taxa.

2075 Kukkonen (1986) indicated that the holotype of $S$. altum was at H, but a thorough search in this 2076 herbarium (H. Väre, pers.com.) has revealed that the specimen is lost, so the isotype at PRE is 2077 selected as the lectotype.

2078

2079

2080

2081

2082

Carex spartea Wahlenb., Kongl. Vetensk. Acad. Nya Handl. 149, 1803.

2083

Type: [South Africa] Cap. bonae Spei, Thunberg (lectotype: UPS-21933 specimen on the right, 2084 digital image! here designated; isolecto- UPS-21933 specimen on the left, digital image!, SBT2085 2086 इ Schoenoxiphium sparteum (Wahlenb.) C.B. Clarke, Bull. Misc. Inform. Kew, Addit. Ser. 8: 67 2087 (1908).

2088 三Archaeocarex spartea (Wahlenb.) Pissjauk. Bot. Mater. Gerb. Bot. Inst. Komarova Akad. 2089 Nauk S.S.S.R. 12: 83 (1950).

2090 三Kobresia spartea (Wahlenb.) T. Koyama, J. Fac. Sci. Univ. Tokyo, Sect. 3, Bot. 8: 80

2091 (1961).

2092 三Uncinia spartea (Wahlenb.) Spreng., Syst. Veg. 3: 830 (1826).

2093 E Uncinia spartea Nees, Linnaea 10: 205 (1835), nom. illeg.

$2094 \equiv$ Uncinia sprengelii Nees, Linnaea 10: 205 (1836), nom. superfl.

2095

2096 = Carex indica Schkuhr, Beschr. Riedgräs. 1: 37 (1801), nom. illeg., non L. (1771).

2097 Type: [South Africa] Cap. bonae Spei, Thunberg (lectotype: HAL-0103917 digital image!, here 2098 designated)

2099 三 Carex spartea Thunb., Fl. Cap. 1: 343 (1811), nom. illeg.; non C. spartea Wahlenb. (1803)

2100

$2101=$ Carex schimperiana Boeckeler, Linnaea 40: 373, 1876. 
2102 Type: Ethiopia. Abyssinia, Dewra Tabor, 8500 ped., 27-VIII-1863, Schimper 1318 (lectotype:

2103 BM-000922720 digital image!, here designated; isolecto-: E-00286063 digital image!, K-

2104000693814 digital image!).

$2105 \equiv$ Schoenoxiphium schimperianum (Boeckeler) C.B.Clarke in Bull. Misc. Inform. Kew, Addit.

2106 Ser. 8: 67 (1908).

2107 इSchoenoxiphium sparteum var. schimperianum (Boeckeler) Kük. in Engler (ed.), Pflanzenr.

2108 38(IV, 20): 32 (1909).

2109

$2110=$ Carex densenervosa Chiov. in Ann. Bot. (Rome) 9: 149. 1911.

2111 Type: [Ethiopia]. Semien pascoli ghiaiosi macchiosi aprici presso Cerà 13-VII-1909, Chiovenda

2112979 (lectotype: FT-000664 digital image!, here designated; isolecto: K-000363532 digital

2113 image!). Syntype: [Ethiopia] Amhara-Dembià, Bamboló pascoli sassosi tra le macchie, 16-VII-

2114 1909, Chiovenda 1041, FT-000665 digital image!).

2115

2116

2117

2118

2119

2120

2121

2122

Rhizome caespitose or not, with short to very long internodes, moderately stout, dark-brown. Flowering culms (4.5)15-50(75) cm long, acutely, more rarely, obtusely trigonous, slightly scabrous at least to the apex, more rarely smooth, leafy up to $2 / 3$ of its length, (0.4)0.6-1(1.4) mm wide at the middle. Leaves (0.4)1.5-3(5) mm wide, shorter, more rarely longer, than the inflorescence, soft to slightly rigid, straight to slightly curved at the apex, light green, flat, more rarely, scarcely carinate, in cross-section, scabrous along the margins and along the abaxial 2123 midrib to the apex; adaxial surface smooth to scarcely aculeate in some veins; ligule (0.5)12.5(3.5) $\mathrm{mm}$ long. Basal sheaths with lamina, more rarely, the lowermost bladeless, usually 2124 densely fibrous. Lowest bract of the inflorescence leaf-like, shorter, rarely longer, than the 2125

2126

2127

2128

2129 inflorescence, with a sheath (9) $13-45 \mathrm{~mm}$ long. Inflorescence up to the upper $3 / 4(4 / 5)$ of the length of the culm, branching up to 3 times; partial inflorescences (3)5-7(8), the (3)4-5(6) lowermost distant, pedunculate and erect, the (1)2-3 uppermost overlapping, subsessile, rarely all sessile and overlapping (in dwarf individuals). Glumiform perigynia and glumiform cladoprophylls 2130

2131

2132

2133

2134

2135

2136

2137

2138

2139

2140 absent. Tubular cladoprophylls always present. Utriculiform cladoprophylls rarely present. Male glumes 2-3.2 $\times(1.2) 1.5-2.2 \mathrm{~mm}$, ovate-lanceolate to widely ovate, straw-coloured to yellowishbrown, with a green central band, acute to ending in an aculeate mucro up to $0.3(0.5) \mathrm{mm}$ long. Female glumes (1.9)2-3.2(3.7) $\times(1) 1.3-1.9(2) \mathrm{mm}$, ovate, yellowish-brown, pale reddish brown or straw coloured, with a green central band, acute to ending in an aculeate mucro up to 2(6) $\mathrm{mm}$ long. Unisexual utricles (2)2.5-3.3(4.1) $\times(0.9) 1.1-1.5(1.8) \mathrm{mm}$, widely ovoid to elipsoid, stipitate, straight, more rarely slightly curved, straw-coloured to brownish when mature, smooth, with conspicuous prominent veins over the entire surface, suberect to erecto-patent, abruptly contracted, very rarely attenuate, into a smooth, occasionally (some individuals from Eastern Cape) with a few, very disperse, minute prickless, asymmetrically bidentate or irregularly truncate beak (0.2)0.5-0.8(1) mm long; rachilla usually reaching the apex of the utricle, rarely

2141 protruding from it up to $0.2(0.4) \mathrm{mm}$. Bisexual utricles frequently present, widely and obliquely truncate at the apex. Achenes (1.8)1.9-2.6(2.9) $\times(0.8) 1-1.2(1.4) \mathrm{mm}$, ellipsoid-trigonous, more 
2142 or less straw-coloured to brown when mature, tipped by a very short, obtusely trigonous,

2143 sometimes slightly and shortly neck-like, rarely asymmetric, persistent style base.

2144

\section{Distribution}

2146 Eastern and southern parts of Africa and southeast of the Arabian Peninsula. Democratic

2147 Republic of the Congo (North Kivu province), Eswatini (Manzini district), Ethiopia (Amhara,

2148 Oromia and Southern Nations regions), Kenya (Baringo, Kericho, Nyandarua and Trans Nzoia

2149 counties), Lesotho (Leribe and Maseru districts), Malawi (Rumphi district), South Africa

2150 (Eastern Cape, Free State, Gauteng, KwaZulu-Natal, Limpopo, Mpumalanga and Western Cape

2151 provinces), Tanzania (Iringa region), Uganda (Northern and Western regions), Republic of

2152 Yemen (Ta'izz governorate) and Zimbabwe (Manicaland province). [23 CON 24 ETH 25 KEN

2153 TAN UGA 26 MLW ZIM 27 CPP LES NAT OFS SWZ TVL 35 YEM]. Fig. 26F.

2154

2155

2156

2157

2158

2159

2160

2161

2162

2163

2164

2165

2166

2167

2168

2169

2170

2171

2172

2173

2174

\section{Habitat}

Dry to damp grassland, edges of streams, grassy clearing of shrubs (Albany Thicket, Fynbos, Grassland, Indian Ocean Coastal Belt and Savanna biomes); 45-2800 m (up to $2310 \mathrm{~m}$ in South Africa).

\section{Etymology}

From the Latin sparteus-a-um, similar to esparto grass (Macrochloa tenacissima (L.) Kunth), a steppary species used for its strong fibers.

\section{Iconography}

Figs. 32C and 34. Gordon-Gray (1995; sub Schoenoxiphium sparteum).

2175

\section{Conservation}

Due to the long-standing problems concerning delimitation of this species, it has not previously been evaluated under the taxonomic concept here proposed, and should therefore be considered Not Evaluated (NE).

2176

2177

\section{Notes}

This species has been often mistaken with the short, narrow leaves and small utricles (3.5-4.2 $\mathrm{mm}$ long) forms of $C$. esenbeckiana, from which it is differentiated because of: i) the light green color of $C$. spartea against the ashen green or bluish-green of $C$. esenbeckiana, ii) lower ratio of beak:body of the utricle length in $C$. spartea, iii) the very short, obtusely trigonous (rarely

2178 slightly and shortly neck-like), persistent style base of $C$. spartea against the distinctly neck-like style base of $C$. esenbeckiana, and iv) C. spartea inhabits sunny meadows, whereas the habitat of

2180 C. esenbeckiana includes areas of permanent shade, generally in forest understories. Carex spartea has also been mistaken with $C$. bolusii, but the latter present noticeable prickles in the utricle beak (very rarely some specimens show the beak almost smooth), basal sheaths entire to 
2182 slightly fibrous, and smooth, obtusely trigonous culms, whereas C. spartea presents a smooth 2183 utricle beak - very rarely, a few individuals from Eastern Cape show some utricles with very 2184 disperse, minute prickles towards the apex-, basal sheaths generally strongly fibrous and culms 2185 more or less acutely trigonous, sometimes with some prickles sparse towards the apex. Finally, 2186 C. spartea is easily differentiated from C. dregeana because of the rachilla length, that in the 2187 latter reaches a maximum of $1 / 2(3 / 4)$ of the utricle length, whereas in C. spartea equals or 2188 surpasses the utricle length. These species are also distinguishable by the superior partial 2189 inflorescences bracts: very wide and with a scarious margin in C. dregeana, and narrower 2190 without bearing the scarious margin in C. spartea.

2191 The specimens of $C$. spartea from its northern distribution tend to present longer leaves that 2192 frequently surpass in length the culms. However, in those areas there are also populations with 2193 leaves shorter than the culms, as well as intermediate specimens.

2194

2195

2196

2197 We have here presented a fully updated and integrative monograph of Carex section 2198 Schoenoxiphium based on morphological, molecular and cytogenetic data. We recognize 21

2199 morphologically well delimited species, and one of them, C. gordon-grayae, has been described 2200

2201

2202

2203

2204

2205

2206

2207

2208

2209

2210

2211

2212

\section{3}

2214

2215

2216

2217

2218

2219

2220

2221 here as a new species. The 20 species included in the phylogenetic study are placed in five well supported clades, except $C$. acocksii (weakly supported here as sister of Clade D, but see Márquez-Corro et al., 2020) and C. gordon-grayae (an independent lineage). Monophyly has been confirmed for all sampled species except for C. sciocapensis that was revealed as paraphyletic, probably due to recent divergence. For the first time, we have reported cytogenetic counts for this section, made on 43 samples and 15 taxa; we have observed a conspicuous reduction of chromosome numbers, probably due to a massive series of fusion events that have occurred through the diversification of the lineage, rather than several polyploid event. Further work is needed to i) investigate the presence of cryptic species in Clades B and C, ii) elucidate the phylogenetic position of $C$. gordon-grayae, and iii) evaluate the potential role of ecological specialization and karyotype-related adaptation in the diversification of the section.

\section{Acknowledgements}

Authors are grateful to B. Gehrke (UIB) for her help during fieldwork, previous works on Carex section Schoenoxiphium and taxonomic comments. J. Muñoz (MA) for the elaboration of distribution maps. C. Potgieter (NU) provided us with the technical support that made chromosomal counts possible at the University of Natal. M. González Muñoz, S. GuerraCárdenas, V. Pineda Labella, J.M. Sierra, M. Pirie and C.H. Stirton, for help during fieldwork. J.C. Zamora for assistance during the nomenclatural survey. The staff and curators of herbaria BOL, E, EA, GRA, H, HAL, NBG, NU, P, PRE, S, SALA, UPOS, UPS for essential help during the study of herbarium collections (in situ visits, digitalization of specimens, search of type 
2222 material, loan management, etc.), especially L. Scott (E), P.M. Musili (EA), V.R. Clark (GRA),

2223

2224

2225

2226

2227

2228

2229

2230

2231

2232

2233

2234

2235

2236

2237

2238

2239

2240

2241

2242

2243

2244

2245

2246

2247

2248

2249

2250

2251

2252

2253

2254

2255

2256

2257

2258

2259

2260

2261

A. Taponen and H. Väre (H), M. Lehnert (HAL), A. Magee (NBG), B. Bytebeier (NU), F. Jabbour (P), C. Archer, L. Makwarela, W. Sepheka and E. van Wyck (PRE), J. Lundberg (S), E. Rico (SALA), C. Barciela, J.M. Cobos, J. Fernández, I. Jurado, R. Mora, M. Parra and J.M. Yáñez (UPOS), and M. Hjertson (UPS).

\section{References}

Al-Khulaidi AW. 2013. Checklist of Flora in Yemen. Available from http://ye.chmcbd.net/implementation/documents/1-flora-final-by-dr.-abdul-wali-al-khulaidi-2013-part-1introduction.pdf. [Accessed December 2020].

Archer C, Balkwill K. 1997. The genus Carex L. (Cyperaceae) in southern Africa: A new species of subgenus Primocarex Kük. from Northern Cape, with notes on the subgenus. South African Journal of Botany 63:342-344.

Blaser HW. 1944. Studies in the morphology of the Cyperaceae II. The prophyll. American Journal of Botany 31:53-64.

Borowiec ML. 2016. AMAS: a fast tool for alignment manipulation and computing of summary statistics. PeerJ 4: e1660. DOI 10.7717/peerj.1660.

Bruhl JJ. 1991. Comparative development of some taxonomically critical floral inflorescence features in Cyperaceae. Australian Journal of Botany 39(2):119-127. DOI 10.1071/BT9910119.

Brummitt RK. 2001. World geographical scheme for recording plant distributions edition 2. International Working Groupon Taxonomic Databases for Plant Sciences (TDWG).

Caurel MF. 1867. Observationes organogeniques sur la fleur femelle des Carex. Annales des Sciences Naturelles. Cinquiéme Série. Botanique 5: 104-111.

Drège JF. 1847a. Vergleichungen der von Ecklon und Zeyher un von Drège gesammelten südafrikanischen Pflanzen (so weit dieselben noch vorhanden) mit den Exemplaren von Zeyher`s neuesten Sammlugen, weiche derselbe zum Verkauf stellt. Linnaea 20(4):183-259.

Drège JF. 1847b. Standörter-Verzeichniss der von C.L. Zeyher in Südafrika gesammelten Pflanzen. Linnaea 19(3):583-598.

Eaton DA, Overcast I. 2020. ipyrad: Interactive assembly and analysis of RADseq datasets. Bioinformatics, 36(8): 2592-2594. DOI 10.1093/bioinformatics/btz966.

Eiten LT. 1976. Inflorescence units in the Cyperaceae. Annals of the Missouri Botanical Garden 63(1):81-112 DOI 10.2307/2395224.

Escudero M, Hipp AL, Waterway M, Valente L. 2012. Diversification rates and chromosome evolution in the most diverse angiosperm genus of the temperate zone (Carex, Cyperaceae).

Molecular Phylogenetics and Evolution 63(3):650-655 DOI 10.1016/j.ympev.2012.02.005. Escudero M, Martín-Bravo S, Mayrose I, Fernández-Mazuecos M, Fiz-Palacios O, Hipp AL, Pimentel M, Jiménez-Mejías P, Valcárcel V, Vargas P, Luceño M. 2014. Karyotypic changes through dysploidy persist longer over evolutionary time than polyploid changes. PLoS One 9(1):e85266. 
2262 Escudero M, Valcárcel V, Vargas P, Luceño M. 2008. Evolution in Carex L. sect.

2263 Spirostachyae (Cyperaceae): A molecular and cytogenetic approach. Organism Diversity \& 2264 Evolution 7(4):271-291 DOI 10.1016/J.ODE.2006.08.006.

2265 Gehrke B, Martín-Bravo S, Muasya M, Luceño M. 2010. Monophyly, phylogenetic position 2266 and the role of hybridization in Schoenoxiphium Nees (Cariceae, Cyperaceae). Molecular

2267 Phylogenetics and Evolution 56(1):380-392 DOI 10.1016/j.ympev.2010.03.036.

2268 Gehrke B, Vrijdaghs A, Smets E, Muasya AM. 2012. Unisexual flowers as a robust

2269 synapomorphy in Cariceae (Cyperaceae)? Evidence for bisexual flowers in Schoenoxiphium.

2270 South African Journal of Botany 78:150-158 DOI 10.1016/j.sajb.2011.06.004.

2271 Global Carex Group. 2015. Making Carex monophyletic (Cyperaceae, tribe Cariceae): a new

2272 broader circumscription. Botanical Journal of the Linnean Society 179(1): 1-42 DOI

$227310.1111 /$ boj.12298.

2274 Goetghebeur P. 1986. Genera Cyperacearum. Een bijdrage tot de kennis van der morfologie,

2275 systematiek en fylogenese van de Cyperaceae-genera. Thesis Gent: 1165.

2276 Gordon-Gray KD. 1995. Cyperaceae of Natal. Strelitzia 2. National Botanical Institute, South

2277 Africa, 218.

2278 Govaerts R, Jiménez-Mejías P, Koopman J, Simpson D, Goetghebeur P, Wilson K,

2279 Egorova T, Bruhl J. 2020. World Checklist of Cyperaceae. Facilitated by the Royal Botanic

2280 Gardens, Kew. Available from http://wcsp.science.kew.org/. [Accessed December 2020].

2281 Guarise NJ, Vegetti AC. 2008. The inflorescences structure of Cyperus L. section Luzuloidei

2282 Kunth (Cyperaceae). Plant Systematics and Evolution 271:41-63 DOI 10.1007/s00606-007-

2283 0590-6.

2284 Haines RW, Lye KA. 1983. The sedges and rushes of East Africa. East African Natural History

2285 Society. Nairobi, Kenya.

2286 Jiménez-Mejías P, Hahn M, Lueders K, Starr JR, Brown BH, Chouinard BN, Chung K-S, 2287 Escudero M, Ford BA, Ford KA, Gebahuer S, Gehrke B, Hoffmann MH, Jin X-F, Jung J, 2288 Kim S, Luceño M, Maguilla E, Martín-Bravo S, Míguez M, Molina A, Naczi R, Pender JE, 2289 Reznicek AA, Villaverde T, Waterway MJ, Wilson KL, Yang J-C, Zhang S, Hipp AL, 2290 Roalson EH (Global Carex Group). 2016. Megaphylogenetic specimen-level approaches to the 2291 Carex (Cyperaceae) phylogeny using regions ITS, ETS, and matK: Implications for 2292 classification. Systematic Botany 41(3):500-518 DOI 10.1600/036364416X692497.

2293 Hipp AL, Escudero M, Chung KS. 2013. Holocentric chromosomes. In: Maloy S, Hughes K, 2294 eds. Brenner's Encyclopedia of Genetics. Elsevier: Amsterdam, 499-501.

2295 Hipp AL, Rothrock PE, Roalson EH. 2009. The evolution of chromosome arrangements in 2296 Carex (Cyperaceae). The Botanical Review 75(1):96-109 DOI 10.1007/s12229-008-9022-8.

2297 Hipp AL, Rothrock PE, Whitkus R, Weber JA. 2010. Chromosomes tell half of the story: the 2298 correlation between karyotype rearrangements and genetic diversity in sedges, a group with 2299 holocentric chromosomes. Molecular Ecology 19(15):3124-3138 DOI 10.1111/j.1365-

2300 294x.2010.04741.x.

2301 Holttum RE. 1948. The spikelet in Cyperaceae. Botanical Review 14(8):525-541. 
2302 ICN 2018. Turland NJ, Wiersema JH, Barrie FR, Greuter W, Hawksworth DL, Herendeen 2303 PS, Kusber W-H, Li D-Z, Marhold K, May TW, McNeill J, Monro AM, Prado J, Price MJ, 2304 Smith GF. International Code of Nomenclature for algae, fungi, and plants (Shenzhen Code)

2305 adopted by the Nineteenth International Botanical Congress Shenzhen, China, July 2017. 2306 Regnum Vegetabile 159. Glashütten, Koeltz Botanical Books DOI 10.12705/Code.2018.

2307 IUCN 2012. IUCN Red List Categories and Criteria, v. 3.1, $2^{\text {nd }}$ Ed. p. 32. Gland, Switzerland \& 2308 Cambridge, UK.

2309 IUCN 2017. Guidelines for using the IUCN Red List Categories and Criteria, v. 13, p. 108.

2310 Prepared by the Standards and Petitions Subcommittee. Species Survival Commission, Gland, 2311 Switzerland \& Cambridge, UK.

2312 IUCN 2020. The IUCN Red List of Threatened Species, v. 2020.1. Available from 2313 Redlist.sanbi.org. [Accessed January 2021].

2314 Kern JH. 1974. Cyperaceae. In Van Steeni CGGJ eds. Flora Malesiana 7. Noordhoff 2315 International Publishing. Leyden.

2316 Kükenthal G. 1909. Cyperaceae-Caricoideae. In: Engler HGA, ed. Das Pflanzenreich. Leipzig: 2317 W. Engelmann 4:1-247.

2318 Kükenthal G. 1910. Cyperaceae novae II. Repertorium novarum specierum regni vegetabilis 2319 8:20-22.

2320 Kukkonen I. 1967. Vegetative anatomy of Uncinia (Cyperaceae-Cariceae). Annals of Botany 2321 31(3):523-544 DOI 10.1093/oxfordjournals.aob.a084161.

2322 Kukkonen I. 1978. Two new species of Schoenoxiphium (Cyperaceae). Botaniska Notiser 2323 131(2):263-267.

2324 Kukkonen I. 1983. The genus Schoenoxiphium (Cyperaceae). A preliminary account. Bothalia 2325 14(3-4):819-823 DOI 10.4102/abc.v14i3/4.1248.

2326 Kukkonen I. 1984. New infraspecific taxa and nomenclatural combinations in Carex

2327 (Cyperaceae) in the Flora Iranica area. Annales Botanici Fennici 21(4):383-389.

2328 Kukkonen I. 1986. Special features of the inflorescence structure in the family Cyperaceae.

2329 Annales Botanici Fennici 23(2):107-119.

2330 Kukkonen I. 1990. On the genus Eleocharis (Cyperaceae) in the Flora Iranica area, with revised 2331 infrageneric classification and nomenclature. Annales Botanici Fennici 27(2):109-117.

2332 Kukkonen I. 1994. Definition of descriptive terms for the Cyperaceae. Annales Botanici Fennici 2333 31(1): 37-43.

2334 Kunth KS. 1838. Flora Berolinensis Berlin 2: 438.

2335 Larridon I, Spalink D, Jiménez-Mejías P, Márquez-Corro JI, Martín-Bravo S, Muasya

2336 AM, Escudero M. 2021. The evolutionary history of sedges (Cyperaceae) in Madagascar.

2337 Journal of Biogeography. DOI 10.1111/jbi.14048.

2338 Levyns MR. 1945. A comparative study of the inflorescence in four species of Schoenoxiphium

2339 and its significance in relation to Carex and its allies. South African Journal of Botany 11:79-89.

2340 Luceño M. 1988. Notas caricológicas III. Anales del Jardín Botánico de Madrid 45(1):189-196. 
2341 Luceño M, Castroviejo S. 1991. Agmatoploidy in Carex laevigata (Cyperaceae). Fusion and 2342 fission of chromosomes as the mechanism of cytogenetic evolution in Iberian populations. Plant 2343 Systematics and Evolution 177:149-159 DOI 10.1007/BF00937952.

2344 Luceño M, Escudero M, Jiménez-Mejías P, Maguilla E, Villaverde T, Gehrke B, Muasya 2345 M, Martín-Bravo. 2013. Carex clade Schoenoxiphium revisited: a molecular and cytogenetic 2346 approach. Monocots V: 5th International Conference on Comparative Biology of 2347 Monocotyledons. The New York Botanical Garden and Fordham University.

2348 Márquez-Corro JI, Jiménez-Mejías P, Helme, NA, Luceño M, Martín-Bravo S. 2020. The

2349 systematic position of the enigmatic rare South African endemic Carex acocksii: Its relevance on

2350 the biogeography and evolution of Carex sect. Schoenoxiphium (Cyperaceae). South African

2351 Journal of Botany 131:475-483 DOI 10.1016/j.sajb.2020.03.027.

2352 Márquez-Corro JI, Maguilla E, Villaverde T, Martín-Bravo S, Luceño M. 2017. Two new 2353 species in Carex sect. Schoenoxiphium (Cyperaceae) from southern Africa. Phytotaxa 303(1):342354 46 DOI 10.11646/phytotaxa.303.1.2.

2355

Márquez-Corro JI, Martín-Bravo S. 2020. Carex acocksii. The IUCN Red List of Threatened

2356 Species 2020: e.T163344043A167071571. [Accessed January 2021].

2357 Márquez-Corro JI, Martín-Bravo S, Jiménez-Mejías P, Hipp AL, Spalink D, Naczi R, 2358 Roalson EH, Luceño M, Escudero M. 2021. Macroevolutionary insights in sedges (Carex: 2359 Cyperaceae): The effects of rapid chromosome number evolution on lineage diversification. 2360 Journal of Systematics and Evolution DOI 10.1111/jse.12730

2361 Márquez-Corro JI, Martín-Bravo S, Pedrosa-Harand A, Hipp AL, Luceño M, Escudero M. 2362 2019a. Karyotype Evolution in Holocentric Organisms. In: eLS. John Wiley \& Sons, Ltd:

2363 Chichester.

2364 Márquez-Corro JI, Martín-Bravo S, Spalink D, Luceño M, Escudero M. 2019b. Inferring 2365 hypothesis-based transitions in clade-specific models of chromosome number evolution in 2366 sedges (Cyperaceae). Molecular Phylogenetics and Evolution 135:203-209 DOI 2367 10.1016/j.ympev.2019.03.006.

2368 Martín-Bravo S, Jiménez-Mejías P, Villaverde T, Escudero M, Hahn M, Spalink D, 2369 Roalson EH, Hipp AL, the Global Carex Group (Benítez-Benítez C, Bruederle LP, Fitzek 2370 E, Ford BA, Ford KA, Garner M, Gebauer S, Hoffmann MH, Jin X-F, Larridon I, 2371 Léveillé-Bourret É, Lu Y-F, Luceño M, Maguilla E, Márquez-Corro JI, Míguez M, Naczi 2372 R, Reznicek AA, Starr JR). 2019. A tale of worldwide success: Behind the scenes of Carex 2373 (Cyperaceae) biogeography and diversification. Journal of Systematics and Evolution 57(6): 2374 695-718 DOI 10.1111/jse.12549.

2375 Mola LM, Papeschi AG. 2006. Holocentric chromosomes at a glance. Journal of Basic \& 2376 Applied Genetics 17(1):17-33.

2377 Molina A, Acedo C, Llamas F. 2012. A comparative study of the inflorescence in the genus 2378 Carex (Cyperaceae). Systematic Botany 37(2):365-381 DOI 10.1600/036364412X635430. 2379 Mucina L, Rutherford MC. 2006. The vegetation of South Africa, Lesotho and Swaziland. 2380 Strelitzia 19. South African National Biodiversity Institute: Pretoria. 
2381 Nees CG. 1832. Plantae Ecklonianae. Cyperaceae. Linnaea 7:491-537.

2382 Raimondo D, von Staden L, Foden W, Victor JE, Helme NA, Turner RC, Kamundi DA, 2383 Manyama PA. 2009. Red List of South African Plants. Strelitzia 25:668. South African National 2384 Biodiversity Institute: Pretoria.

2385 Reutemann A, Lucero L, Guarise N, Vegetti A. 2012. Structure of the Cyperaceae 2386 inflorescence. Botanical Review 78(2):184-204 DOI 10.1007/s12229-012-9098-z.

2387 Reznicek AA. 1990. Evolution in sedges (Carex, Cyperaceae). Canadian Journal of Botany 2388 68(7):1409-1432 DOI 10.1139/b90-180.

2389 Richards JH, Bruhl JJ, Wilson KL. 2006. Flower or spikelet? Understanding the morphology 2390 and development of reproductive structures in Exocarya (Cyperaceae, Mapanioideae, 2391 Chrysitricheae). American Journal of Botany 93(9):1241-1250.

2392 Roalson EH. 2008. A synopsis of chromosome number variation in the Cyperaceae. The 2393 Botanical Review 74(2):209-393 DOI 10.1007/s12229-008-9011-y.

2394 Roalson EH, Jiménez-Mejías P, Hipp AL, Benítez-Benítez C, Bruederle LP, Chung K-S, 2395 Escudero M, Ford BA, Ford K, Gebauer S, Gehrke B, Hahn M, Hayat MQ, Hoffmann 2396 MH, Jin X-F, Kim S, Larridon I, Léveillé-Bourret É, Lu Y-F, Luceño M, Maguilla E, 2397 Márquez-Corro JI, Martín-Bravo S, Masaki T, Míguez M, Naczi RFC, Reznicek AA, 2398 Spalink D, Starr JR, Uzma, Villaverde T, Waterway MJ, Wilson KL, Zhang S. 2020. A 2399 framework infrageneric classification of Carex (Cyperaceae) and its organizing principles. 2400 Journal of Systematics and Evolution. DOI 10.1111/jse.12722.

2401 SANBI 2020. Red List of South African Plants, v. 2020.1. Available from Redlist.sanbi.org. 2402 [Accessed January 2021].

2403 Smith DL, Faulkner JS. 1976. The inflorescence of Carex and related genera. The Botanical 2404 Review 42(1):53-81.

2405 Snell RS. 1936. Anatomy of the spikelet and flowers of Carex, Kobresia and Uncinia. Bulletin 2406 of the Torrey Botanical Club 63:277-295.

2407 Stafleu FA, Cowan RS. 1976. Taxonomic literature: a selective guide to botanical publications 2408 and collections with dates, commentaries and types. 2nd edition. Utrecht: Bohn, Scheltema \& 2409 Holkema.

2410 Stamatakis A. 2014. RAxML version 8: a tool for phylogenetic analysis and post-analysis of 2411 large phylogenies. Bioinformatics 30(9):1312-1313 DOI 10.1093/bioinformatics/btu033.

2412 Starr JR, Ford BA. 2009. Phylogeny and evolution in Cariceae (Cyperaceae): current 2413 knowledge and future directions. The Botanical Review 75(1):110-137 DOI 10.1007/s122292414 008-9020-x.

2415 Timonen T. 1998. Synflorescence structure of Schoenoxiphium lanceum (Cyperaceae). Annales 2416 Botanici Fennici 26(3):319-342.

2417 Thiers B. 2020. Index Herbariorum: A global directory of public herbaria and associated staff. 2418 New York Botanical Garden's Virtual Herbarium. Available from https://sweetgum.nybg.org/ih/ 2419 [Accessed December 2020]. 
2420 Vegetti AC. 2002. Typological reinterpretation of the inflorescences in Cariceae (Cyperaceae).

2421 Phyton-Annales Rei Botanicae 42(1):159-167.

2422 Vegetti AC. 2003. Synflorescence typology in Cyperaceae. Annales Botanici Fennici 40(1):35-

242346 ISSN 0003-3847.

2424 Victor JE. 2002. South Africa. In: Golding JS (Ed.). Southern African Plant Red Data Lists.

2425 Southern African Botanical Diversity Network Report 14:93-120. SABONET, Pretoria.

2426 Villaverde T, Jiménez-Mejías P, Luceño M, Waterway MJ, Kim S, Lee B, Rincón-Barrado

2427 M, Hahn M, Maguilla E, Roalson EH, Hipp AL, The Global Carex Group. 2020. A new

2428 classification of Carex (Cyperaceae) subgenera supported by a HybSeq backbone phylogeny

2429 tree. Botanical Journal of the Linnean Society 194(2):141-163 DOI 10.1093/botlinnean/boaa042.

2430 Villaverde T, Maguilla E, Escudero M, Márquez-Corro JI, Jiménez-Mejías P, Gehrke B,

2431 Martín-Bravo S, Luceño M. 2017. New insights into the systematics of the Schoenoxiphium

2432 clade (Carex, Cyperaceae). International Journal of Plant Sciences 178(4):320-329 DOI

$243310.1086 / 691144$.

2434 Villaverde T, Maguilla E, Luceño M, Hipp A. 2021. Assessing the sensitivity of divergence

2435 time estimates to locus-sampling, calibration points, and model priors in a RAD-seq phylogeny

2436 of Carex section Schoenoxiphium. Journal of Systematics and Evolution. DOI:

$2437 \quad 10.1111 /$ jse. 12724

2438 Vrijdaghs A, Muasya AM, Goetghebeur P, Caris P, Nagels A, Smets E. 2009. A floral

2439 ontogenetic approach to questions of homology within the Cyperoideae (Cyperaceae). Botanical

2440 Review 75(1):30-51 DOI 10.1007/s12229-008-9021-9.

2441 Vrijdaghs A, Reynders M, Larridon I, Muasya AM, Smets E, Goetghebeur P. 2010.

2442 Spikelet structure and development in Cyperoideae (Cyperaceae): a monopodial general model

2443 based on ontogenetic evidence. Annals of Botany 105(4):555-571 DOI 10.1093/aob/mcq010.

2444 Wahl HA. 1940. Chromosome numbers and meiosis in the genus Carex. American Journal of

2445 Botany 27(7):458-470 DOI 10.1002/j.1537-2197.1940.tb14707.x.

2446 Waterway MJ, Hoshino T, Masaki T. 2009. Phylogeny, species richness, and ecological

2447 specialization in Cyperaceae tribe Cariceae. Botanical Review 75(1): 138-159 DOI

2448 10.1007/s12229-008-9024-6.

2449 Waterway MJ, Starr JR. 2007. Phylogenetic relationships in tribe Cariceae (Cyperaceae) based

2450 on nested analyses of four molecular data sets. Aliso 23(1):165-192 DOI

2451 10.5642/ALISO.20072301.13. 


\section{Table $\mathbf{1}$ (on next page)}

Main taxonomic treatments of Carex section Schoenoxiphium.

Clades are based on Villaverde et al., (2017), Márquez-Corro et al., (2020) and this study. ${ }^{1}$ Geographically limited to East Tropical Africa. ${ }^{2}$ Geographically limited to Kwazulu-Natal (South Africa). ${ }^{3}$ Unsampled in molecular phylogenies, tentative assignment to Clade A based on morphology of the type specimen. ${ }^{4}$ Márquez-Corro et al. (2017), C. bolusii C.B. Clarke is the correct name of $C$. parvirufa Luceño \& Márq.-Corro, see below. 


\begin{tabular}{|c|c|c|c|c|c|}
\hline $\begin{array}{l}\text { Kükenthal } \\
\text { (1909) }\end{array}$ & $\begin{array}{l}\text { Kukkonen }(1978,1983 \text {, } \\
\text { 1986) }\end{array}$ & Haines \& Lye (1983) & $\begin{array}{l}\text { Gordon-Gray } \\
\left(\mathbf{1 9 9 5 ) ^ { 2 }}\right.\end{array}$ & \begin{tabular}{|l} 
Global Carex \\
Group (2015), \\
Villaverde et al., \\
(2017)
\end{tabular} & This study \\
\hline & & & & Clade A & Clade A \\
\hline & $\begin{array}{l}\text { Schoenoxiphium gracile } \\
\text { Cherm. }\end{array}$ & & & $\begin{array}{l}\text { Carex chermezonii } \\
\text { Luceño \& Martín- } \\
\text { Bravo }^{3}\end{array}$ & $\begin{array}{l}\text { Carex chermezonii } \\
\text { Luceño \& Martín- } \\
\text { Bravo }^{3}\end{array}$ \\
\hline \multirow[t]{5}{*}{$\begin{array}{l}\text { S. lanceum } \\
\text { (Thunb.) Kük. }\end{array}$} & $\begin{array}{l}\text { S. lanceum (Thunb.) } \\
\text { Kük. }\end{array}$ & & & $\begin{array}{l}\text { C. lancea (Thunb.) } \\
\text { Baill. }\end{array}$ & $\begin{array}{l}\text { C. lancea (Thunb.) } \\
\text { Baill. }\end{array}$ \\
\hline & $\begin{array}{l}\text { S. madagascariense } \\
\text { Cherm. }\end{array}$ & & $\begin{array}{l}\text { S. madagascariense } \\
\text { Cherm. }\end{array}$ & $\begin{array}{l}\text { C. multispiculata } \\
\text { Luceño \& Martín- } \\
\text { Bravo }\end{array}$ & $\begin{array}{l}\text { C. multispiculata } \\
\text { Luceño \& Martín- } \\
\text { Bravo }\end{array}$ \\
\hline & $\begin{array}{l}\text { S. schweickerdtii } \\
\text { Merxm. \& Podlech }\end{array}$ & & $\begin{array}{l}\text { S. schweickerdtii } \\
\text { Merxm. \& Podlech }\end{array}$ & $\begin{array}{l}\text { C. schweickerdtii } \\
\text { (Merxm. \& } \\
\text { Podlech) Luceño \& } \\
\text { Martín-Bravo }\end{array}$ & $\begin{array}{l}\text { C. schweickerdtii } \\
\text { (Merxm. \& } \\
\text { Podlech) Luceño \& } \\
\text { Martín-Bravo }\end{array}$ \\
\hline & & & & & Clade B \\
\hline & S. basutorum Turrill & & $\begin{array}{l}\text { S. basutorum } \\
\text { Turrill }\end{array}$ & $\begin{array}{l}\text { C. basutorum } \\
\text { (Turrill) Luceño \& } \\
\text { Martín-Bravo }\end{array}$ & $\begin{array}{l}\text { C. basutorum } \\
\text { (Turrill) Luceño \& } \\
\text { Martín-Bravo }\end{array}$ \\
\hline
\end{tabular}




\begin{tabular}{|c|c|c|c|c|}
\hline & & $\begin{array}{l}\text { S. burkei C.B. } \\
\text { Clarke }\end{array}$ & $\begin{array}{l}\text { C. burkei } \\
\text { (C.B.Clarke) } \\
\text { Luceño \& Martín- } \\
\text { Bravo }\end{array}$ & $\begin{array}{l}\text { C. burkei } \\
\text { (C.B.Clarke) } \\
\text { Luceño \& Martín- } \\
\text { Bravo }\end{array}$ \\
\hline & S. distinctum Kukkonen & $\begin{array}{l}\text { S. distinctum } \\
\text { Kukkonen }\end{array}$ & $\begin{array}{l}\text { C. distincta } \\
\text { (Kukkonen) Luceño } \\
\text { \& Martín-Bravo }\end{array}$ & $\begin{array}{l}\text { C. distincta } \\
\text { (Kukkonen) Luceño } \\
\text { \& Martín-Bravo }\end{array}$ \\
\hline & S. filiforme Kük. & S. filiforme Kük. & C. killickii Nelmes & C. killickii Nelmes \\
\hline & S. molle Kukkonen & & & \\
\hline & S. strictum Kukkonen & & & \\
\hline & & & & Clade C \\
\hline \multirow[t]{4}{*}{ S. ecklonii Nees } & S. ecklonii Nees & & \multirow[t]{2}{*}{ C. capensis Thunb. } & C. capensis Thunb. \\
\hline & S. altum Kukkonen & & & $\begin{array}{l}\text { C. sciocapensis } \\
\text { Luceño, Márq.- } \\
\text { Corro \& Sánchez- } \\
\text { Villegas }\end{array}$ \\
\hline & & & & Clade D \\
\hline & S. perdensum Kukkonen & $\begin{array}{l}\text { S. perdensum } \\
\text { Kukkonen }\end{array}$ & \begin{tabular}{|l|} 
C. perdensa \\
(Kukkonen) Luceño \\
\& Martín-Bravo
\end{tabular} & $\begin{array}{l}\text { C. perdensa } \\
\text { (Kukkonen) Luceño } \\
\text { \& Martín-Bravo }\end{array}$ \\
\hline
\end{tabular}




\begin{tabular}{|c|c|c|c|c|c|}
\hline $\begin{array}{l}\text { S. kunthianum } \\
\text { Kük. }\end{array}$ & & $\begin{array}{l}\text { S. caricoides C.B. } \\
\text { Clarke }\end{array}$ & $\begin{array}{l}\text { S. caricoides C.B. } \\
\text { Clarke }\end{array}$ & $\begin{array}{l}\text { C. spartea } \\
\text { Wahlenb. }\end{array}$ & C. dregeana Kunth \\
\hline $\begin{array}{l}\text { S. sparteum } \\
\text { (Wahlenb.) C.B. } \\
\text { Clarke }\end{array}$ & $\begin{array}{l}\text { S. sparteum (Wahlenb.) } \\
\text { C.B. Clarke }\end{array}$ & $\begin{array}{l}\text { S. sparteum (Wahlenb.) } \\
\text { C.B. Clarke }\end{array}$ & $\begin{array}{l}\text { S. sparteum } \\
\text { (Wahlenb.) C.B. } \\
\text { Clarke }\end{array}$ & & $\begin{array}{l}\text { C. spartea } \\
\text { Wahlenb. }\end{array}$ \\
\hline $\begin{array}{l}\text { S. sparteum var. } \\
\text { schimperianum } \\
\text { (Boeckeler) Kük. }\end{array}$ & & & $\begin{array}{l}\text { S. schimperianum } \\
\text { (Boeckeler) C.B. } \\
\text { Clarke }\end{array}$ & $\begin{array}{l}\text { C. schimperiana } \\
\text { Boeckeler }\end{array}$ & \\
\hline \multirow{3}{*}{$\begin{array}{l}\text { S. sparteum var. } \\
\text { lehmannii (Nees) } \\
\text { Kük. }\end{array}$} & $\begin{array}{l}\text { S. lehmannii (Nees) } \\
\text { Steud. }\end{array}$ & $\begin{array}{l}\text { S. lehmannii (Nees) } \\
\text { Steud. }\end{array}$ & $\begin{array}{l}\text { S. lehmannii (Nees) } \\
\text { Steud. }\end{array}$ & $\begin{array}{l}\text { C. uhligii K.Schum. } \\
\text { ex C.B.Clarke }\end{array}$ & $\begin{array}{l}\text { C. esenbeckiana } \\
\text { Boeckeler }\end{array}$ \\
\hline & & & & & Clade E \\
\hline & & & $\begin{array}{l}\text { S. ludwigii sensu } \\
\text { Gordon-Gray, non } \\
\text { Hochst. }\end{array}$ & & $\begin{array}{l}\text { C. badilloi Luceño } \\
\& \text { Márq.-Corro }\end{array}$ \\
\hline $\begin{array}{l}\text { S. buchananii } \\
\text { C.B. Clarke ex } \\
\text { Kük. }\end{array}$ & & & $\begin{array}{l}\text { S. buchananii C.B. } \\
\text { Clarke }\end{array}$ & $\begin{array}{l}\text { C. kukkoneniana } \\
\text { Luceño \& Martín- } \\
\text { Bravo }\end{array}$ & $\begin{array}{l}\text { C. kukkoneniana } \\
\text { Luceño \& Martín- } \\
\text { Bravo }\end{array}$ \\
\hline S. rufum Nees & S. rufum Nees & S. rufum Nees & S. rufum Nees & $\begin{array}{l}\text { C. ludwigii } \\
\text { (Hochst.) Luceño \& } \\
\text { Martín-Bravo }\end{array}$ & $\begin{array}{l}\text { C. ludwigii } \\
\text { (Hochst.) Luceño \& } \\
\text { Martín-Bravo }\end{array}$ \\
\hline
\end{tabular}




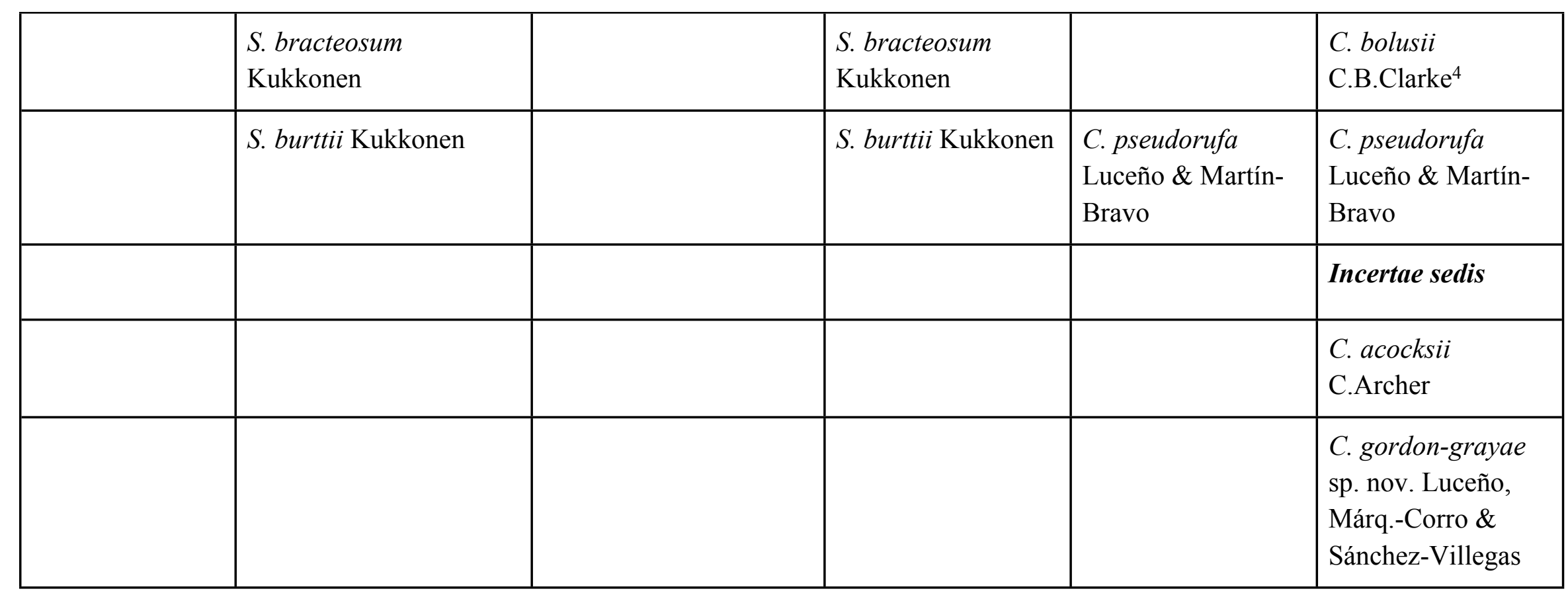




\section{Table 2 (on next page)}

Cytogenetic results.

Species names, chromosome number (in Metaphase I or Pollen Grain Mitosis), inferred diploid chromosome number and information of population of origin are indicated. Populations data include country, province, locality, collection code (in bold) and the herbarium where the witness voucher is preserved. The symbols I, II and III represent univalent, bivalent and trivalent chromosome association, respectively. 


\begin{tabular}{|c|c|c|c|}
\hline Species & $\begin{array}{l}\text { Chromosome } \\
\text { number }\end{array}$ & $\begin{array}{l}\text { Inferred } \\
2 \mathrm{n}\end{array}$ & Populations \\
\hline \multicolumn{4}{|l|}{ Clade A } \\
\hline C. lancea & $\begin{array}{l}\mathbf{2 n}=\mathbf{4 4}{ }^{\mathrm{II}} \text { in } \\
M I\end{array}$ & 88 & $\begin{array}{l}\text { South Africa, Western Cape, Table } \\
\text { Mountain. IX-2009. 4544MM (BOL). }\end{array}$ \\
\hline \multirow[t]{3}{*}{$\begin{array}{l}\text { C. } \\
\text { multispiculata }\end{array}$} & $\begin{array}{l}\mathbf{2 n}=\mathbf{3 1} 1^{\mathrm{II}} \text { in } \\
M I\end{array}$ & 62 & $\begin{array}{l}\text { Two populations: South Africa, } \\
\text { KwaZulu-Natal, Cathedral Peak Nature } \\
\text { Reserve, 11-XI-2012, 53EMS12(1) } \\
\text { (UPOS). Ibidem, 2287 m, 58EMS12 } \\
\text { (UPOS). }\end{array}$ \\
\hline & 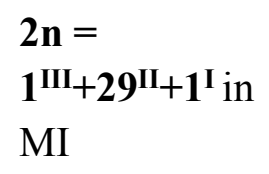 & 62 & $\begin{array}{l}\text { South Africa, KwaZulu-Natal, Cathedral } \\
\text { Peak Natural Reserve, } 1711 \text { m, 11-XI- } \\
\text { 2012, 53EMS12(2) (UPOS). }\end{array}$ \\
\hline & $\begin{array}{l}\mathbf{2 n}=\text { ca. } \mathbf{6 2} \text { in } \\
\text { premeiotic } \\
\text { mitosis }\end{array}$ & ca. 62 & $\begin{array}{l}\text { South Africa, KwaZulu-Natal, } \\
\text { Mlambonja Wilderness area, } 1700 \text { m, 17- } \\
\text { XI-2010, 129SMB10 (UPOS). }\end{array}$ \\
\hline $\begin{array}{l}\text { C. } \\
\text { schweickerdtii }\end{array}$ & $\begin{array}{l}\mathbf{2 n}=30^{\mathrm{II}} \text { in } \\
\mathrm{MI}\end{array}$ & 60 & $\begin{array}{l}\text { South Africa, KwaZulu-Natal, Cathedral } \\
\text { Peak Nature Reserve, } 2287 \text { m, 11-XI- } \\
\text { 2012, 57EMS12 (UPOS). }\end{array}$ \\
\hline
\end{tabular}

\section{Clade B}

\begin{tabular}{|c|c|c|c|}
\hline \multirow[t]{3}{*}{ C. burkei } & $\begin{array}{l}\mathbf{2 n}=\mathbf{3 3}^{\text {II }} \text { in } \\
M I\end{array}$ & 66 & $\begin{array}{l}\text { South Africa, KwaZulu-Natal, Garden } \\
\text { Castle Nature Reserve, } 1803 \text { m, 16-XI- } \\
\text { 2012, 83EMS12 (UPOS). }\end{array}$ \\
\hline & $\begin{array}{l}\mathbf{2 n}=\mathbf{3 5}^{\mathrm{II}} \text { in } \\
M I\end{array}$ & 70 & $\begin{array}{l}\text { South Africa, KwaZulu-Natal, road to } \\
\text { Sani Pass, } 2258 \text { m, 21-XI-2010, } \\
\text { 158SMB10 (UPOS). }\end{array}$ \\
\hline & $\begin{array}{l}\mathbf{2 n}=\mathbf{3 6}^{\mathrm{II}} \text { in } \\
M I\end{array}$ & 72 & $\begin{array}{l}\text { South Africa, Western Cape, W of } \\
\text { Teepunt, Nuweveldberge, } 1844 \text { m, 4-III- } \\
\text { 2008, Clark } 51 \text { (UPOS). }\end{array}$ \\
\hline C. killickii & $\begin{array}{l}2 \mathrm{n}=\mathbf{1}^{\mathrm{III}}+34^{\mathrm{II}} \\
\text { in MI }\end{array}$ & 71 & $\begin{array}{l}\text { South Africa, KwaZulu-Natal, Garden } \\
\text { Castel Forest Reserve, } 2286 \text { m, 19-XI- } \\
\text { 2010, 134SMB10 (UPOS). }\end{array}$ \\
\hline
\end{tabular}




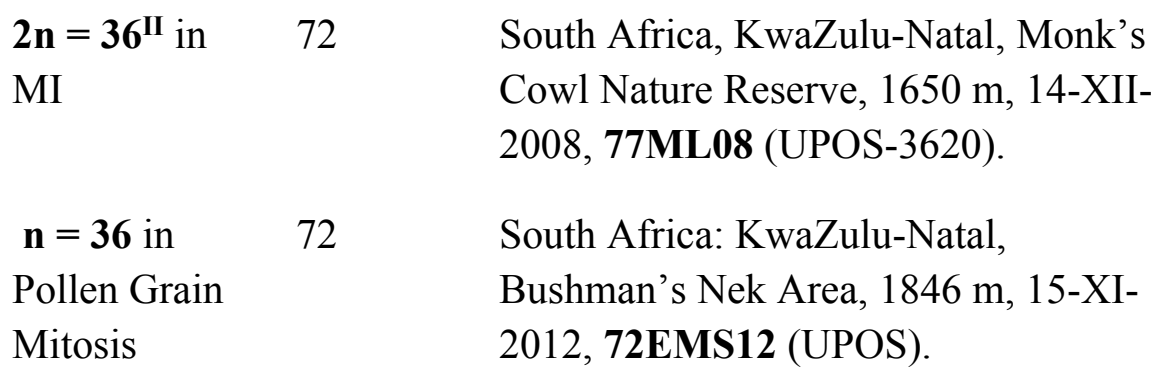

\section{Clade C}

\begin{tabular}{|c|c|c|c|}
\hline C. capensis & $\begin{array}{l}\mathbf{n}=\mathbf{3 6} \text { in } \\
\text { Pollen Grain } \\
\text { Mitosis }\end{array}$ & 72 & $\begin{array}{l}\text { South Africa, Western Cape, Overberg } \\
\text { area (BOL). }\end{array}$ \\
\hline
\end{tabular}
C. sciocapensis $\mathbf{n}=\mathbf{3 4}$ in 68 South Africa, Western Cape, Kannaland, Pollen Grain Towerkop Nature Reserve, 906-968 m, Mitosis 12-X-2017. 142JMC17bis (UPOS).

\section{Clade D}

\begin{tabular}{|c|c|c|c|}
\hline \multirow[t]{2}{*}{ C. perdensa } & $\mathbf{1 5}^{\mathrm{II}}$ in $\mathrm{MI}$ & 30 & $\begin{array}{l}\text { South Africa, KwaZulu-Natal, } \\
\text { Bushman's Nek, } 1804 \text { m, 15-IX-2012, } \\
\text { 74EMS12 (two individuals; UPOS). } \\
\text { Ibidem, } 1850 \text { m, 20-XI-2010, 152SMB10 } \\
\text { (UPOS). }\end{array}$ \\
\hline & $\begin{array}{l}\mathbf{n}=\mathbf{1 5} \text { in } \\
\text { Pollen Grain } \\
\text { Mitosis }\end{array}$ & 30 & $\begin{array}{l}\text { South Africa: KwaZulu-Natal, } \\
\text { Bushman's Nek, } 1804 \text { m, 15-IX-2012, } \\
\text { 74EMS12 (UPOS). }\end{array}$ \\
\hline \multirow[t]{2}{*}{ C. spartea } & $\begin{array}{l}\mathrm{n}=\mathbf{1 2} \text { in } \\
\text { Pollen Grain } \\
\text { Mitosis }\end{array}$ & 24 & $\begin{array}{l}\text { South Africa, KwaZulu-Natal, } \\
\text { Bushman's Nek Natural Reserve, } 1800 \\
\text { m, 20-XI-2010, 154SMB10 (UPOS). }\end{array}$ \\
\hline & $\begin{array}{l}\mathbf{n}=\mathbf{1 3} \text { in } \\
\text { Pollen Grain } \\
\text { Mitosis }\end{array}$ & 26 & $\begin{array}{l}\text { South Africa, Western Cape, Mossel Bay, } \\
325 \text { m, 14-X-2017, 183JMC17 (UPOS). }\end{array}$ \\
\hline \multirow[t]{2}{*}{ C. dregeana } & $\begin{array}{l}\mathbf{2 n}=\mathbf{1 6}^{\mathrm{II}} \text { in } \\
\mathrm{MI}\end{array}$ & 32 & $\begin{array}{l}\text { South Africa, Free State, Scheepershoek, } \\
\text { XI-2009, M. Muasya 4947MM (BOL). }\end{array}$ \\
\hline & $\begin{array}{l}\mathbf{n}=\mathbf{1 7} \text { in } \\
\text { Pollen Grain }\end{array}$ & 34 & $\begin{array}{l}\text { South Africa, KwaZulu-Natal, } \\
\text { Bushman's Nek, } 1779 \text { m, 15-XI-2012, }\end{array}$ \\
\hline
\end{tabular}


Mitosis

$\mathbf{2 n}=17^{\mathrm{II}}$ in

34

MI

C. dregeana $\mathrm{x}$

C. spartea $\mathbf{n}=13,14$ in

Pollen Grain

Mitosis

70EMS12a (UPOS).

South Africa, KwaZulu-Natal, near

Boston, 1450 m, 8-X-2009, 4900bMM

Two populations: South Africa, KwaZulu-Natal, Bushman's Nek, 1779 m, 15-XI-2012, 70EMS12d (UPOS). South Africa, KwaZulu-Natal, Garden Castle Nature Reserve, 1803 m, 16-XI2012, 84EMS12 (UPOS).

n $=12,13,14 \quad 26$

in Pollen

Grain Mitosis

$\mathrm{n}=\mathbf{1 4}, \mathbf{1 5}, 16$

in Pollen

Grain Mitosis

C. $\quad \mathbf{2 n}=\mathbf{1 3}^{\mathrm{II}}$ in 26

esenbeckiana MI
South Africa, KwaZulu-Natal, Bushman's Nek, 1800 m, 20-XI-2010, 155SMB10 (UPOS).

South Africa, KwaZulu-Natal, Bushman's Nek, 1850 m, 20-XI-2010, 153SMB10 (UPOS).

Three populations: Kenya, Laikipia county, Ndaragwa forest, 2300 m, 25VII-2007, 70UPO-K (UPOS). South Africa, Western Cape, Table Mountain. 17-II-2012, 6459MM (BOL). Ibidem, South Africa, Brown Hooded Kingfisher path, 14/X/2017.

\section{Clade E}

\begin{tabular}{|c|c|c|c|}
\hline \multirow[t]{2}{*}{ C. badilloi } & $\begin{array}{l}\mathbf{n}=\mathbf{1 7} \text { in } \\
\text { Pollen Grain } \\
\text { Mitosis }\end{array}$ & 34 & $\begin{array}{l}\text { South Africa, KwaZulu-Natal, Garden } \\
\text { Castle, } 1860 \text { m, 16-IX-2012, 76EMS12a } \\
\text { (UPOS). }\end{array}$ \\
\hline & $\begin{array}{l}\mathbf{n}=\mathbf{1 8} \text { in } \\
\text { Pollen Grain } \\
\text { Mitosis }\end{array}$ & 36 & Ibidem, 76EMS12b (UPOS). \\
\hline
\end{tabular}

C. ludwigii $\quad \mathbf{2 n}=\mathbf{1 7}^{\mathrm{II}}$ in $\quad 34$

MI
Three populations: South Africa, KwaZulu-Natal, Garden Castle Nature Reserve, 1810 m, 16-XII-2008, 106ML08 (UPOS). Ibidem, road to Sani 
Pass, 2225 m, 21-XI-2010, 162SMB10

(UPOS). Ibidem, 159SMB10 (UPOS).

$\mathbf{n}=\mathbf{1 7}$ in

34

Three populations: South Africa,

Pollen Grain

KwaZulu-Natal, Nganang river,

Mitosis

Drakensberg Gardens hotel, 1794

m, 9-XI-2009, 4922MM (UPOS). Ibidem, road to Sani Pass, $2225 \mathrm{~m}, 21-\mathrm{XI}-2010$, 162SMB10 (UPOS). Ibidem, 159SMB10 (UPOS).

C. bolusii $\quad \mathbf{2 n}=\mathbf{1 8}^{\mathrm{II}}$ in $\quad 36$ MI

Two populations: South Africa, Free State, Golden Gate Highlands National Park, 1967 m, 15-I-2010, 42ML10 (UPOS). Ibidem, Bushman's Nek Nature Reserve, 1779 m, 15-XI-2012, 70EMS12b (UPOS).

$\mathbf{n}=\mathbf{1 8}$ in 36

Two populations: South Africa, Free Pollen Grain State, Golden Gate Highlands National Mitosis Park, 1800-2000 m, 13-XII-2008, $143 S M B 08$ (UPOS). Ibidem, KwaZuluNatal, Garden Castle Nature Reserve, 1803 m, 16-XI-2012, 77EMS12 (UPOS). Ibidem, 2267 m, 19-XI-2010, 141SMB10 (UPOS).

$\begin{array}{llll}\text { C. pseudorufa } & \mathbf{2 n}=\mathbf{3 2}^{\mathrm{II}} \text { in } & 64 & \begin{array}{l}\text { South Africa, KwaZulu-Natal, Cathedral } \\ \text { Peak Nature Reserve, 2307 m, 11-XI- } \\ \end{array} \\ & & \text { 2012, 59EMS12 (UPOS) }\end{array}$




\section{Table 3(on next page)}

Summary of the distribution, habitat and elevation range of the species of Carex section Schoenoxiphium accepted in this monograph grouped by the main lineages retrieved in the molecular phylogenies 


\begin{tabular}{|c|c|c|c|}
\hline Species & Distribution & Habitat & Elevation \\
\hline \multicolumn{4}{|l|}{ Clade A } \\
\hline C. chermezonii & Madagascar & Mountain forests & c. $2500 \mathrm{~m}$ \\
\hline C. lancea & South Africa (SA) & $\begin{array}{l}\text { Edges of streams and other } \\
\text { damp and shady places in } \\
\text { forest }\end{array}$ & $20-1500 \mathrm{~m}$ \\
\hline C. multispiculata & $\begin{array}{l}\text { Eswatini, } \\
\text { Madagascar and } \\
\text { SA }\end{array}$ & $\begin{array}{l}\text { Edges of streams, meadows } \\
\text { and other damp places in } \\
\text { mountains }\end{array}$ & $1100-2800 \mathrm{~m}$ \\
\hline C. schweickerdtii & $\begin{array}{l}\text { Lesotho, SA and } \\
\text { Zimbabwe }\end{array}$ & $\begin{array}{l}\text { Stony meadows and, more } \\
\text { rarely, edges of streams and } \\
\text { pools in mountains }\end{array}$ & $1400-3100 \mathrm{~m}$ \\
\hline \multicolumn{4}{|l|}{ Clade B } \\
\hline C. basutorum & Lesotho, SA & $\begin{array}{l}\text { Dry slopes and grassland in } \\
\text { scrubs }\end{array}$ & $1500-2100 \mathrm{~m}$ \\
\hline C. burkei & Lesotho, SA & $\begin{array}{l}\text { Grassland, clearing of shrub, } \\
\text { usually in dry places, but } \\
\text { sometimes in temporary } \\
\text { flooded meadows and edges } \\
\text { of streams }\end{array}$ & $1400-2900 \mathrm{~m}$ \\
\hline C. distincta & Lesotho, SA & $\begin{array}{l}\text { Open, stony and usually dry } \\
\text { meadows and shrubs at high } \\
\text { altitudes }\end{array}$ & $\begin{array}{l}(1990) 2300- \\
3000 \mathrm{~m}\end{array}$ \\
\hline
\end{tabular}




\begin{tabular}{|l|l|l|l|}
\hline C. killickii & Lesotho, SA & $\begin{array}{l}\text { Open, stony and dry to } \\
\text { mesophilous meadows, and } \\
\text { shrubs, usually at high } \\
\text { altitudes }\end{array}$ & $\begin{array}{l}\text { (550)1650-3150 } \\
\mathrm{m}\end{array}$ \\
\hline
\end{tabular}

\section{Clade C}

\begin{tabular}{|l|l|l|l|}
\hline C. capensis & SA & $\begin{array}{l}\text { Open and sunny places in } \\
\text { renosterveld vegetation, } \\
\text { growing on shale soils, } \\
\text { commonly observed in after- } \\
\text { fire vegetation fynbos }\end{array}$ & $5-750 \mathrm{~m}$ \\
\hline C. sciocapensis & SA & $\begin{array}{l}\text { Shady places, mainly in } \\
\text { margins and clearing of } \\
\text { southern afrotemperate forest, } \\
\text { but also in fynbos areas, } \\
\text { especially on shale and } \\
\text { sandstone soils }\end{array}$ & $1500 \mathrm{~m}$ \\
\hline
\end{tabular}

\section{Clade D}

\begin{tabular}{|c|c|c|c|}
\hline C. acocksii & SA & $\begin{array}{l}\text { Open grounds on dolerite } \\
\text { summits }\end{array}$ & $1450-1600 \mathrm{~m}$ \\
\hline C. perdensa & SA & Grassland & $1200-1950 \mathrm{~m}$ \\
\hline C. spartea & $\begin{array}{l}\text { E \& S Africa and } \\
\text { SE Arabian } \\
\text { Peninsula }\end{array}$ & $\begin{array}{l}\text { Dry to damp grassland, edges } \\
\text { of streams, grassy clearing of } \\
\text { shrubs }\end{array}$ & $\begin{array}{l}45-2800 \mathrm{~m} \text { (up } \\
\text { to } 2310 \mathrm{~m} \text { in } \\
\text { South Africa) }\end{array}$ \\
\hline C. dregeana & $\begin{array}{l}\text { E \& S of Africa, W } \\
\text { of Angola and } \\
\text { Madagascar }\end{array}$ & Grassland & $200-2850 \mathrm{~m}$ \\
\hline
\end{tabular}




\begin{tabular}{|l|l|l|l|} 
C. esenbeckiana & E \& S of Africa & $\begin{array}{l}\text { Shady places, mainly in forest } \\
\text { understories }\end{array}$ & 4-2300 m \\
\hline
\end{tabular}

\section{Clade E}

\begin{tabular}{|l|l|l|l|}
\hline C. badilloi & Lesotho, SA & $\begin{array}{l}\text { Mesophilous, open grassland } \\
\text { on clay soils }\end{array}$ & $1750-2500 \mathrm{~m}$ \\
\hline C. bolusii & Lesotho, SA & $\begin{array}{l}\text { Edges of streams, grasslands, } \\
\text { damp meadows and open } \\
\text { bushy places }\end{array}$ & $\begin{array}{l}(1400) 1650- \\
3150 \mathrm{~m}\end{array}$ \\
\hline C. kukkoneniana & $\begin{array}{l}\text { E Africa, from } \\
\text { Tanzania to SA }\end{array}$ & $\begin{array}{l}\text { Edges of streams, marshy } \\
\text { grounds and other damp soils } \\
\text { in mountains }\end{array}$ & $950-2500 \mathrm{~m}$ \\
\hline C. ludwigii & Lesotho, SA & $\begin{array}{l}\text { Edges of streams and other } \\
\text { damp places in mountains }\end{array}$ & $1350-2850 \mathrm{~m}$ \\
\hline C. pseudorufa & SA & $\begin{array}{l}\text { Edges of streams and other } \\
\text { wet places in mountains }\end{array}$ & $1850-3200 \mathrm{~m}$ \\
\hline
\end{tabular}

\section{Incertae sedis}

\begin{tabular}{|l|l|l|l|}
\hline C. gordon-grayae & SA & $\begin{array}{l}\text { Shady places, mainly in } \\
\text { margins and clearing of } \\
\text { forests in the KwaZulu-Natal- } \\
\text { Eastern Cape Coastal Belt }\end{array}$ & $170-400 \mathrm{~m}$ \\
\hline
\end{tabular}




\section{Figure 1}

Inflorescence structure in Carex section Schoenoxiphium.

(A) Partial inflorescence of a complex inflorescence showing the different branching orders and prophylls. (B) Simple inflorescence with a single branching order. Illustration by M. Sánchez-Villegas. 





Figure 2

Types of fertile prophylls in Carex section Schoenoxiphium.

(A) Unisexual utricle. (B) Bisexual utricle. (C) Utriculiform cladoprophyll. (D) Unisexual glumiform perigynium. (E) Bisexual glumiform perigynium. (F) Glumiform cladoprophyll. Illustration by M. Sánchez-Villegas. 



Peer) reviewing PDF | (2021:02:57694:1:1:NEW 25 Mar 2021) 


\section{Figure 3}

Species richness of Carex section Schoenoxiphium.

A) Complete distribution of Schoenoxiphium by clade. Countries are colored to reflect their Schoenoxiphium species richness in a brown color scale, between 1 (lightest brown) and 20 (darkest brown). (B) Distribution of Schoenoxiphium by clade in South Africa, Lesotho and Eswatini. Dot colors indicate a particular clade, whose species are indicated in Table 1. Total number of Schoenoxiphium species per country and South African provinces is indicated. (C) Distribution of clade A in southern Africa. (D) Distribution of clade B in southern Africa. (E) Distribution of clade $C$ in southern Africa. (F) Distribution of clade $D$ in southern Africa. (G) Distribution of clade $E$ in southern Africa. (H) Distribution of unplaced species in southern. The distribution of the species was mapped using $R$. 
A

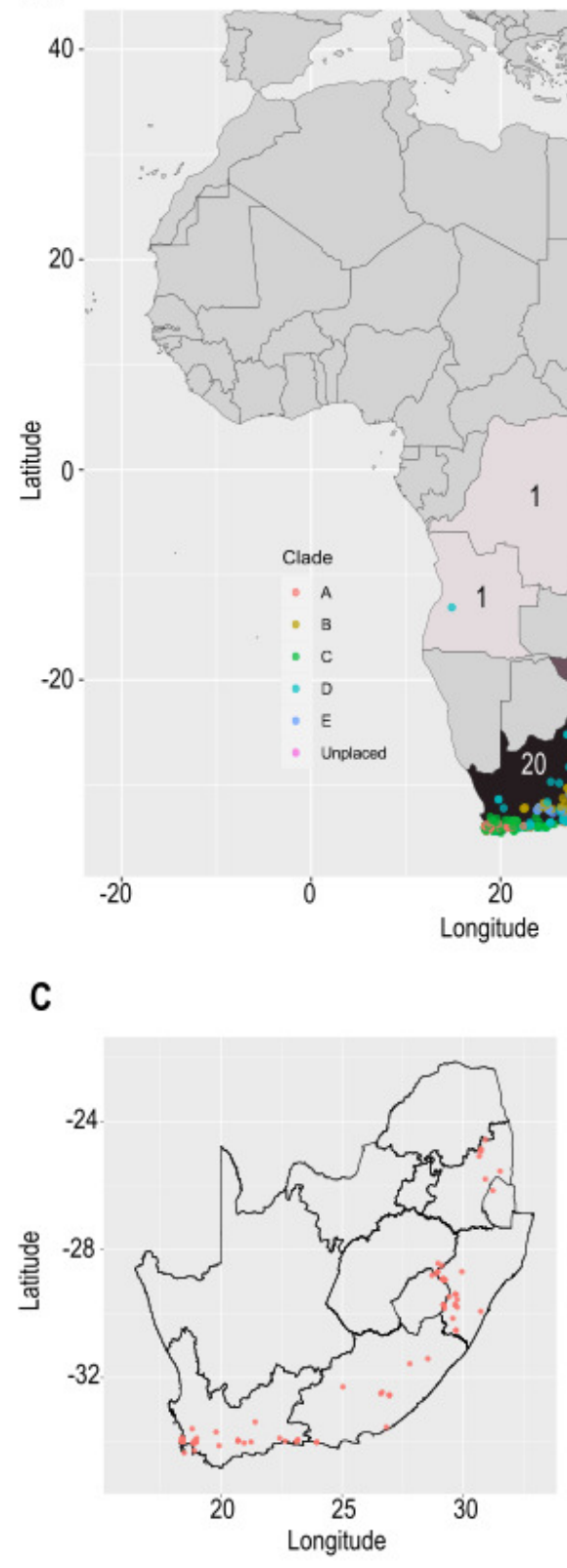

F

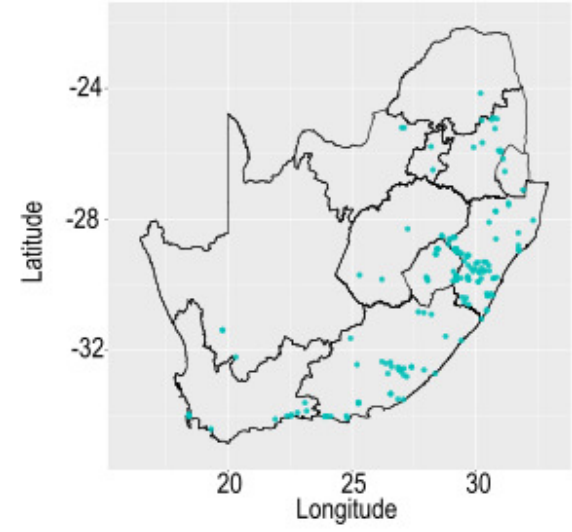

D

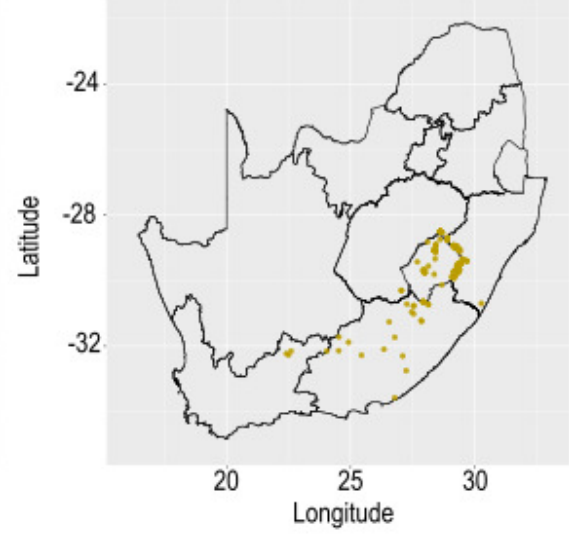

G



B



E

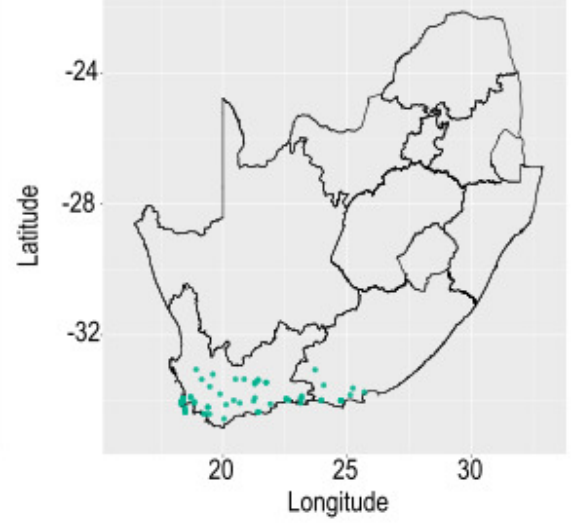

H

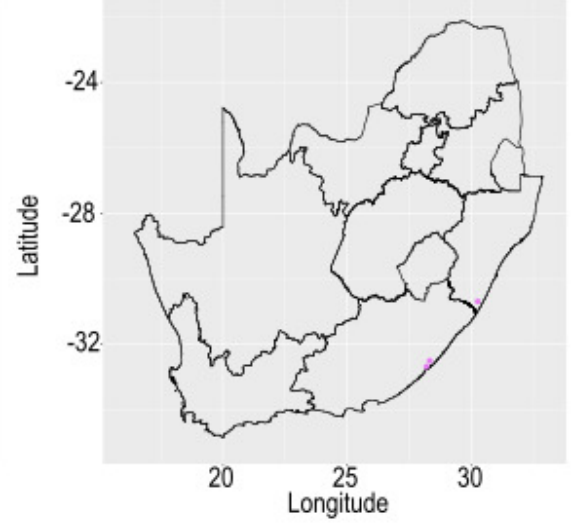


Figure 4

Phylogenetic relationships within Carex section Schoenoxiphium

(A) Maximum likelihood trees obtained from the RAxML analysis using a combined matrix of ETS, ITS, matK, and rps16 DNA regions (120 samples, 2,944bp). (B) Maximum likelihood trees obtained from the RAXML analysis using a RAD-seq matrix of (54 samples, $4,478,844$ bp). Numbers above branches corresponding to bootstrap values are shown (only if $>0.9$ ). Lateral colored squares indicate names of the clades. Inferred chromosome numbers (2n) are indicated for all counted species. See Figs. S1-S2 for expanded trees.

A

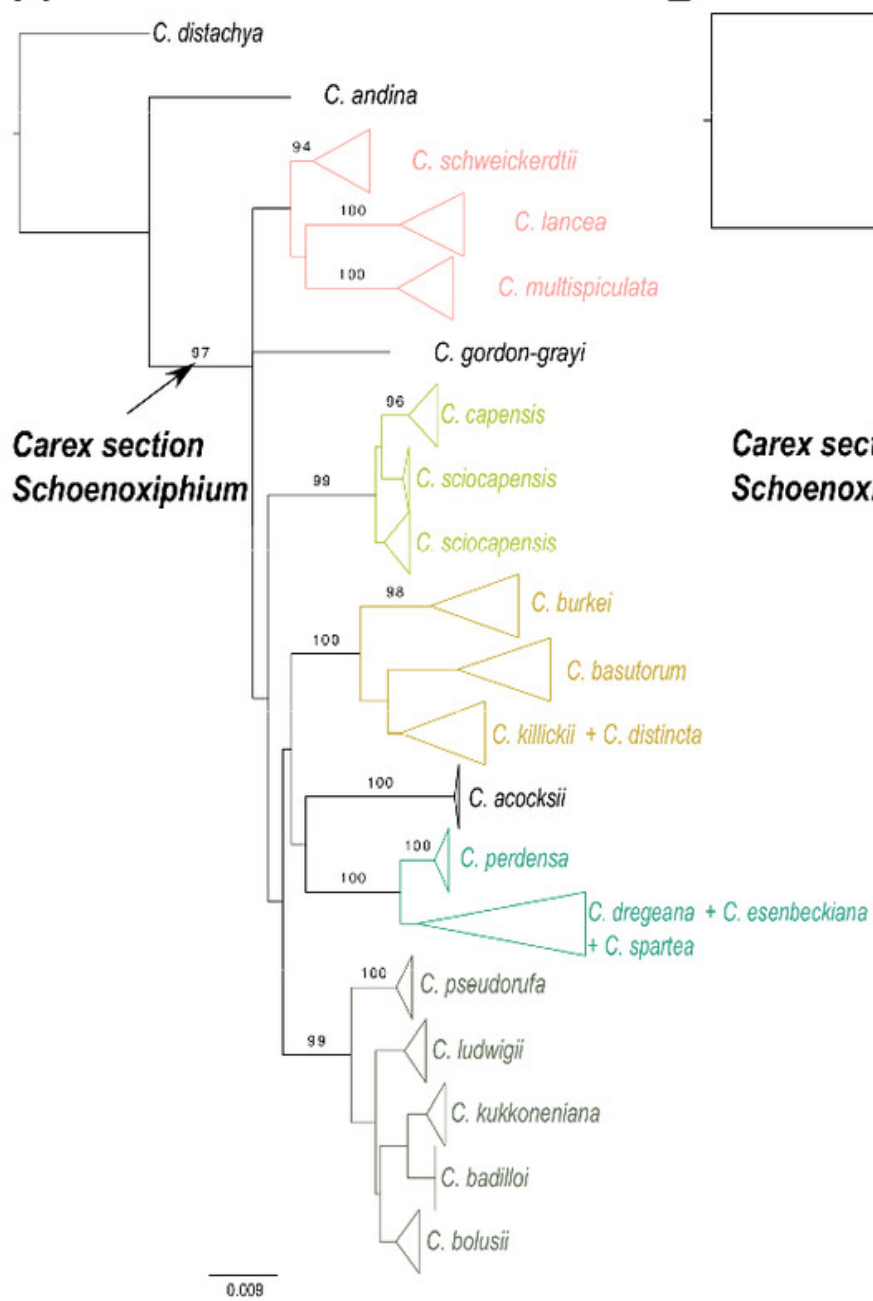

B






\section{Figure 5}

Chromosome counts for all the configurations found in Carex section Schoenoxiphium.

(A) C. schweickerdtii (57EMS12, 30"). (B) C. lancea (MM4544, 44"). (C) C. multispiculata (53EMS12, 1"'+29" $+1^{\prime}$ and 31", respectively). (D-F) C. burkei (83EMS12, 33"; 158SMB10, 35"; Clark51, 36"). (G-H) C. killickii (134SMB10, 1"'+34"; 77ML08, 36"). (I) C. capensis (Western Cape, $n=36)$. (J) C. sciocapensis (142JMC17bis, $n=34)$. (K) C. pseudorufa (59EMS12, 32"). (L) C. bolusii (42ML10, 18"). (M) C. badilloi (76EMS12a,b; $\mathrm{n}=17$ and 18, respectively). (N) C. ludwigii (78EMS12, $\mathrm{n}=17)$. (0) C. perdensa (74EMS12, 15"). (P-Q) C. spartea (MM4947, 16"; 70EMS12a, $n=17$ ). (R) C. uhligii (70UPO-K, 13"). (S-T) C. schimperiana (154SMB10, $n=12$; 183JMC17, $n=13$ ). (U) C. spartea $\times$ C. schimperiana (155SMB10, $n=12,13$ and 14 , respectively). (V) C. spartea $\times$ C. schimperiana (153SMB10, $n=15$ and 16, respectively). The symbols I, II and III represent univalent, bivalent and trivalent chromosome association, respectively. Scale bar at bottom right $=10 \mu \mathrm{m}$. 


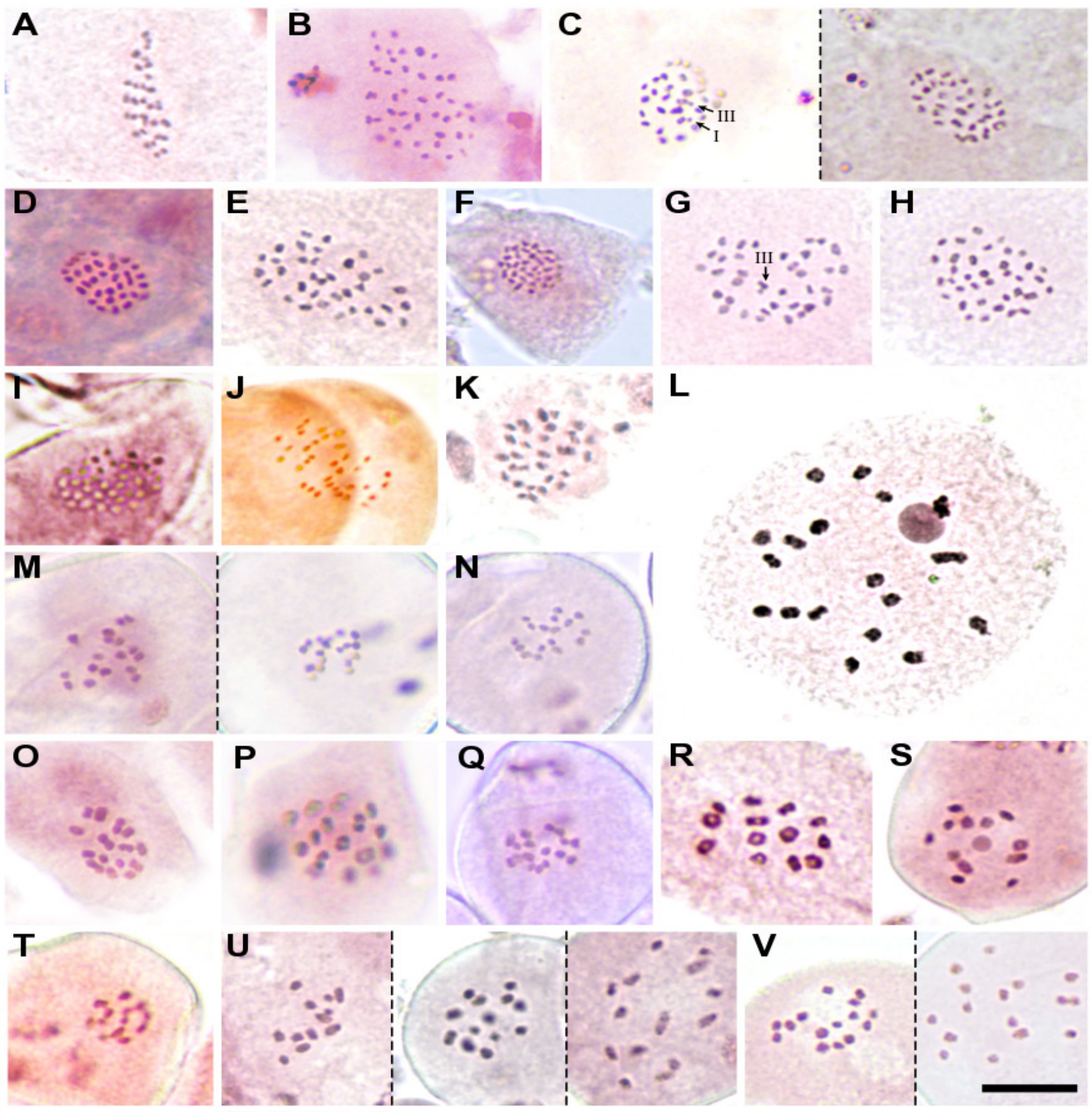


Figure 6

Distribution map of different species of Carex section Schoenoxiphium.

(A) C. acocksii. (B) C. badilloi. (C) C. basutorum. (D) C. bolusii. (E) C. burkei. (F) C. capensis.

(G) C. chermezonii. (H) C. distincta. Maps created with QGIS. 
A

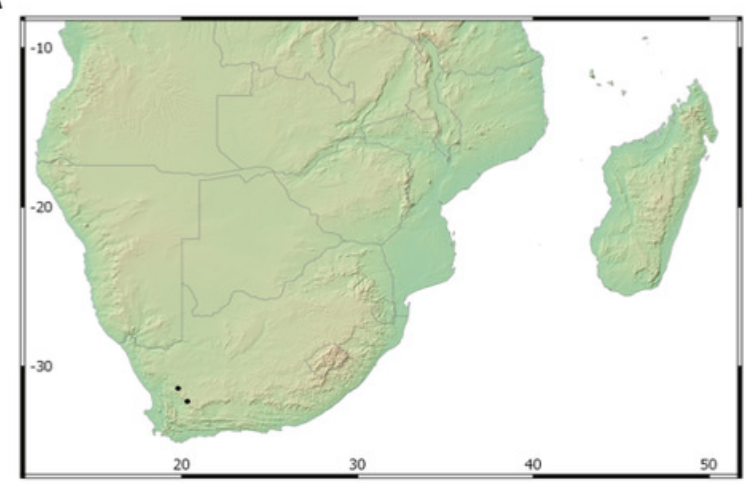

C



E

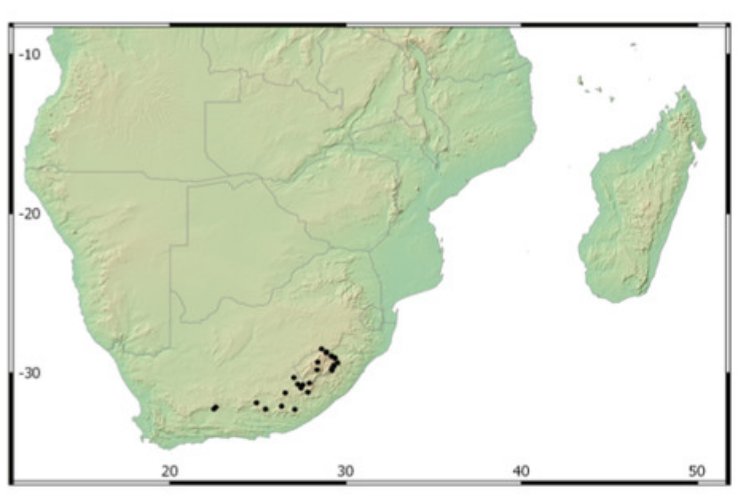

G

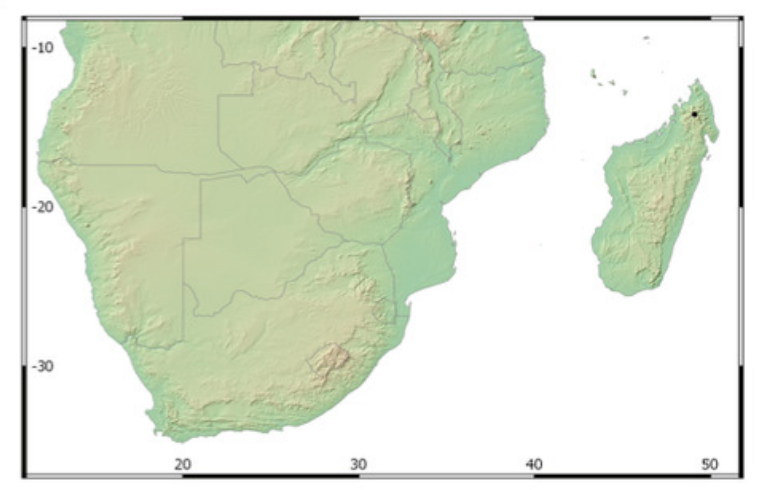

B

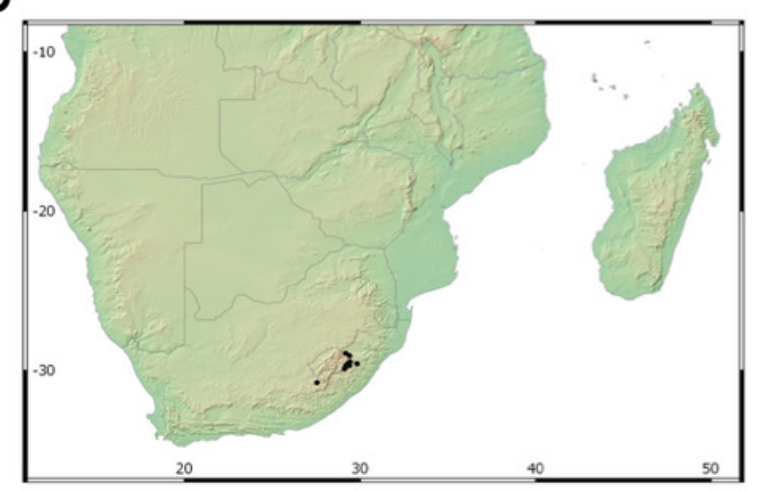

D

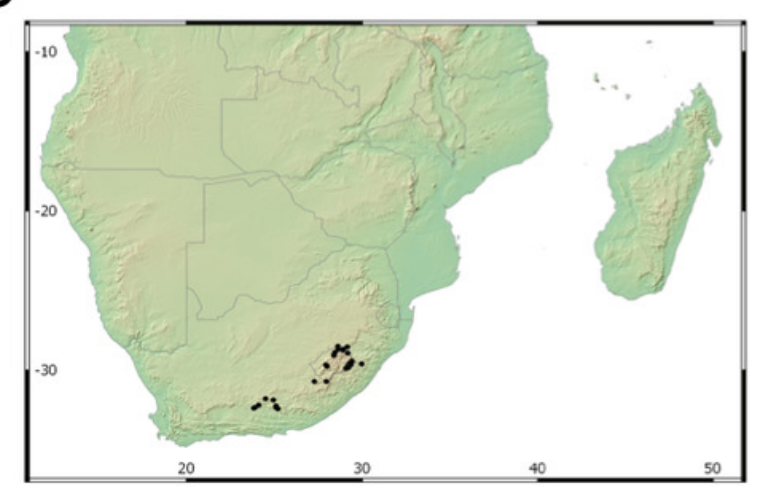

F

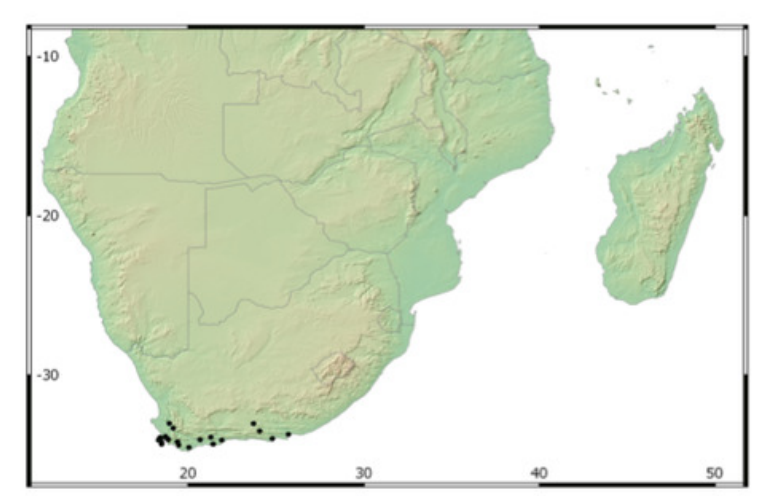

$\mathrm{H}$

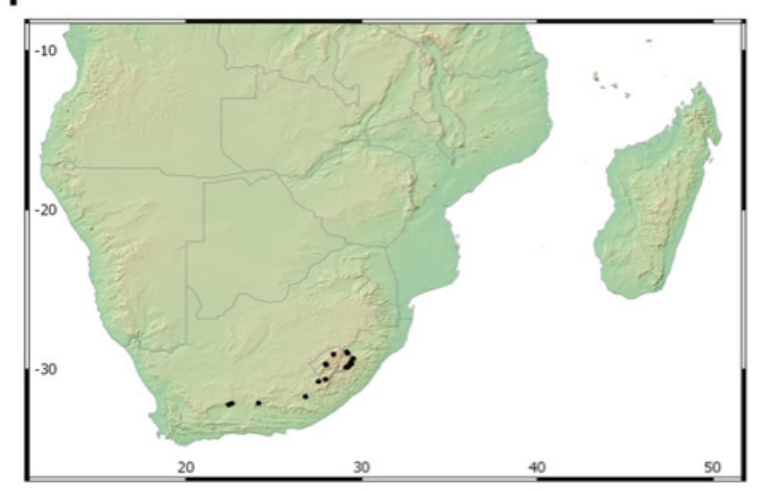


Figure 7

Illustration of Carex acocksii

(A) General aspect of the plant. (B) Inflorescence. (C) Female glume. (D) Male glume. (E) Utricle. (F) Achene. Illustration by M. Sánchez-Villegas. 

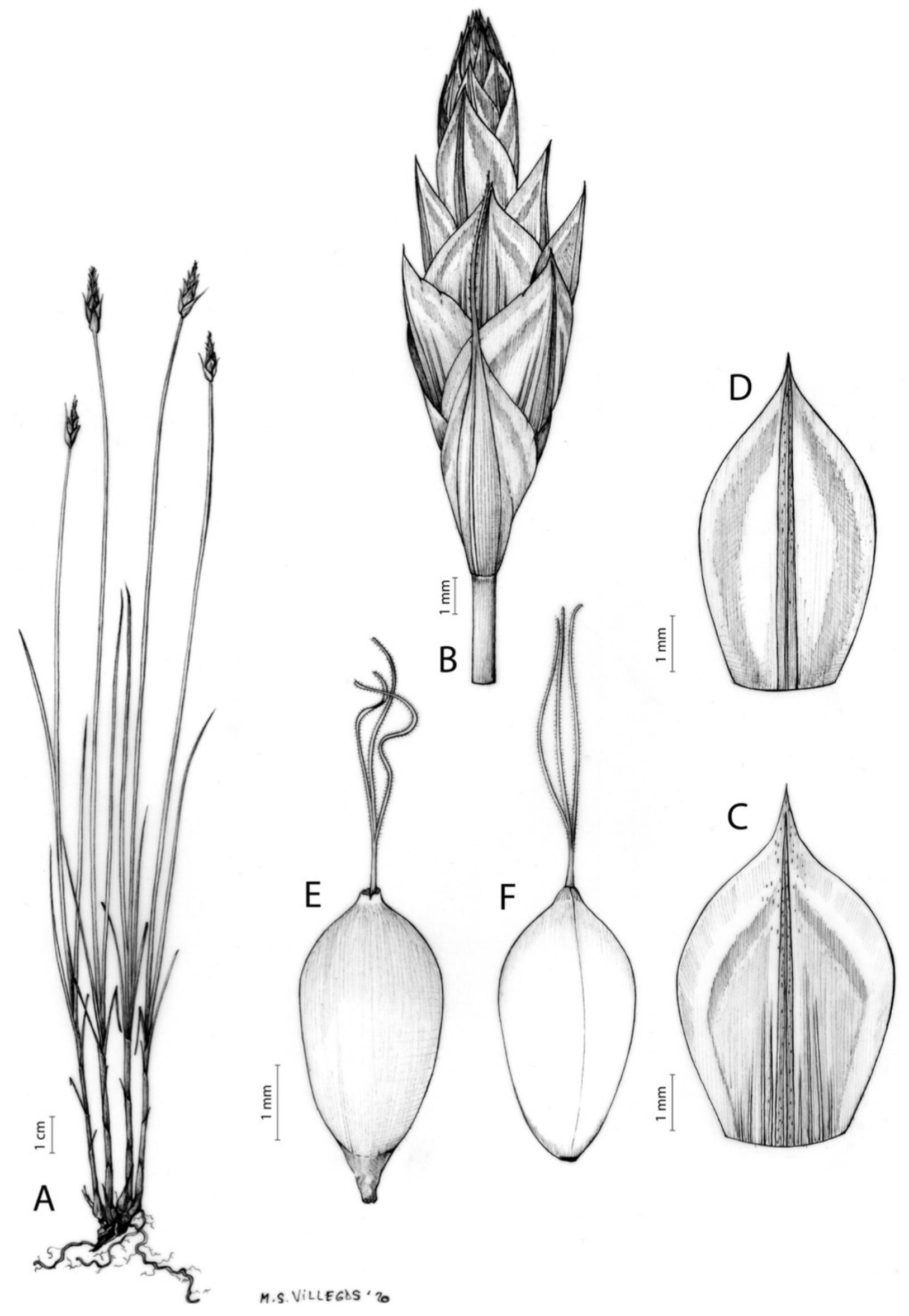

Peer) reviewing PDF | (2021:02:57694:1:1:NEW 25 Mar 2021) 
Figure 8

Morphology of different species of Carex section Schoenoxiphium

(A) C. acocksii. (B) C. badilloi. (C) C. basutorum. (D) C. bolusii. (E) C. burkei. (F) C. capensis.

(G) C. distincta. Photos by M. Luceño. 

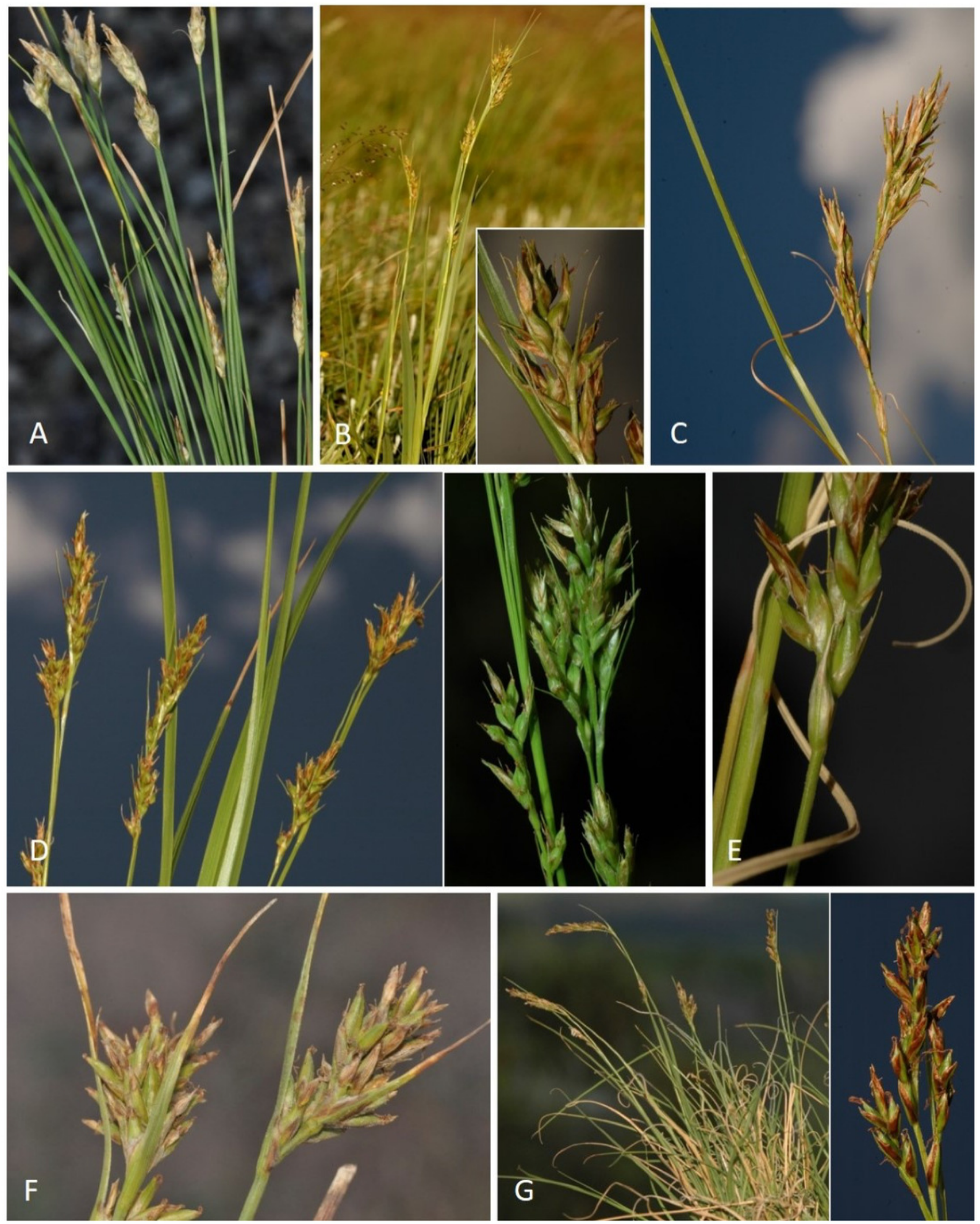
Figure 9

Illustration of Carex badilloi

A) General aspect of the plant. (B) Second order branch of the inflorescence. (C) Utriculiform cladoprohyll. (D) Male glume. (E) Female glume. (F) Unisexual utricle. (G) Achene. (H) Bisexual utricle after removing the male spikelet. Illustration by R. Tavera. 


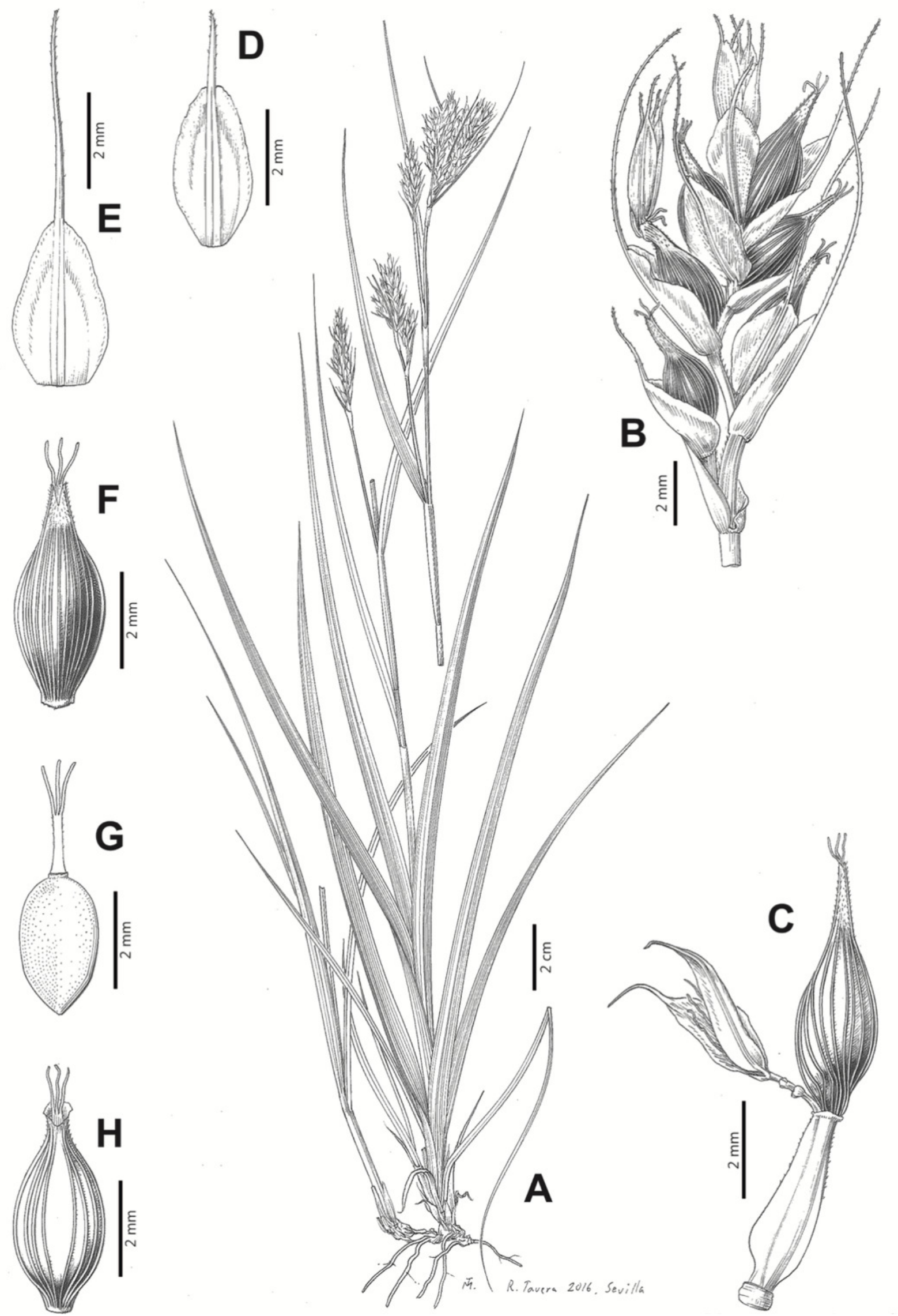

Peer] reviewing PDF | (2021:02:57694:1:1:NEW 25 Mar 2021) 


\section{Figure 10}

Illustration of Carex basutorum

(A) General aspect of the base of the plant and one fertile culm showing the inflorescence.

(B) Second order branch showing an utriculiform cladoprophyll. (C) Male glume. (D) Female glume. (E) Unisexual utricle. (F) Achene. Illustration by M. Sánchez-Villegas. 

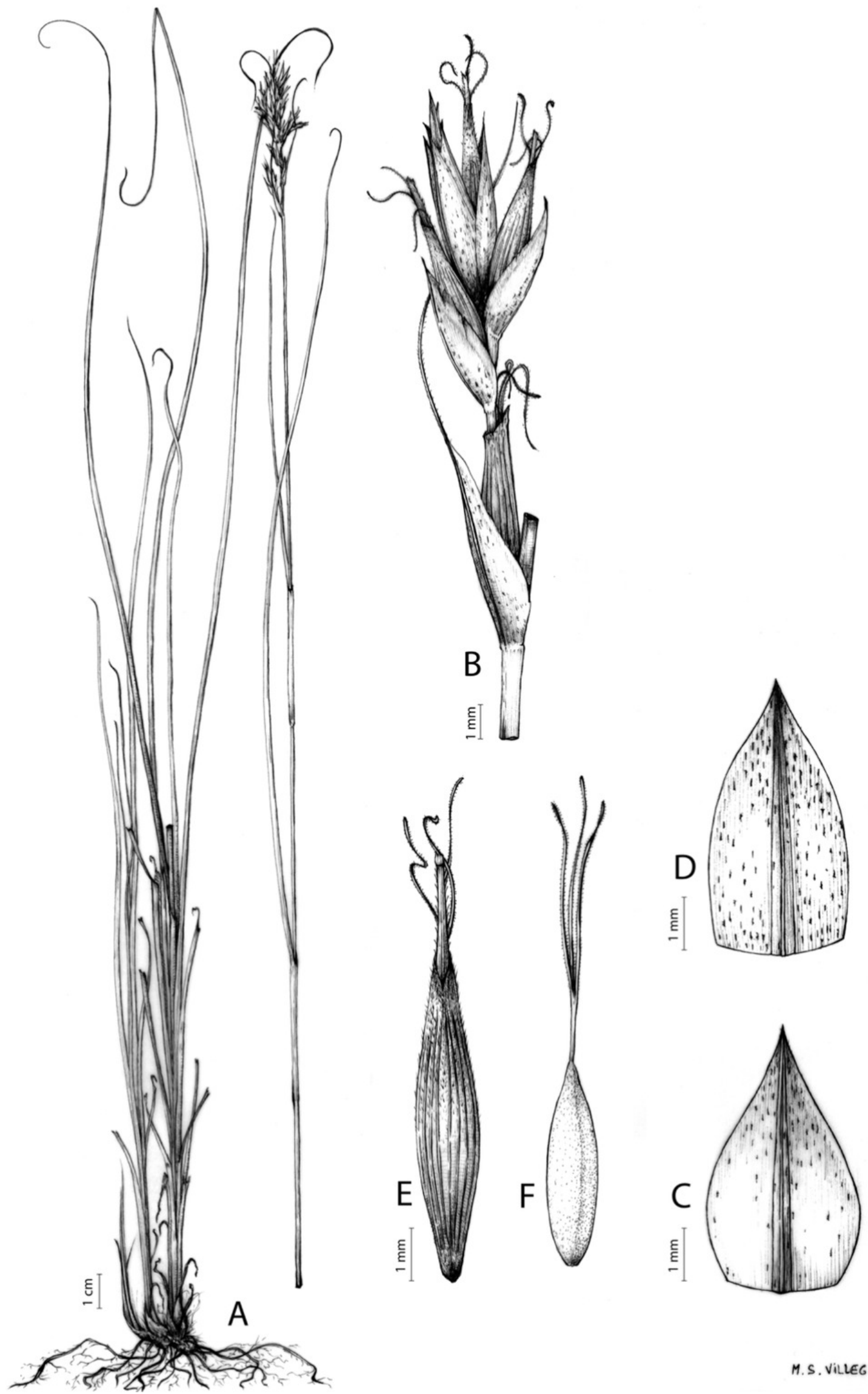

Peer) reviewing PDF | (2021:02:57694:1:1:NEW 25 Mar 2021) 


\section{Figure 11}

\section{Illustration of Carex bolusii}

(A) General aspect of the plant showing several fertile culms. (B) Second order branch of the inflorescence; (C-D) Utriculiform cladoprohylls. (E) Female glume. (F) Male glume. (G) Unisexual utricle. $(\mathrm{H})$ Achene. (I) Bisexual utricle after removing the male spikelet. Illustration by R. Tavera. 


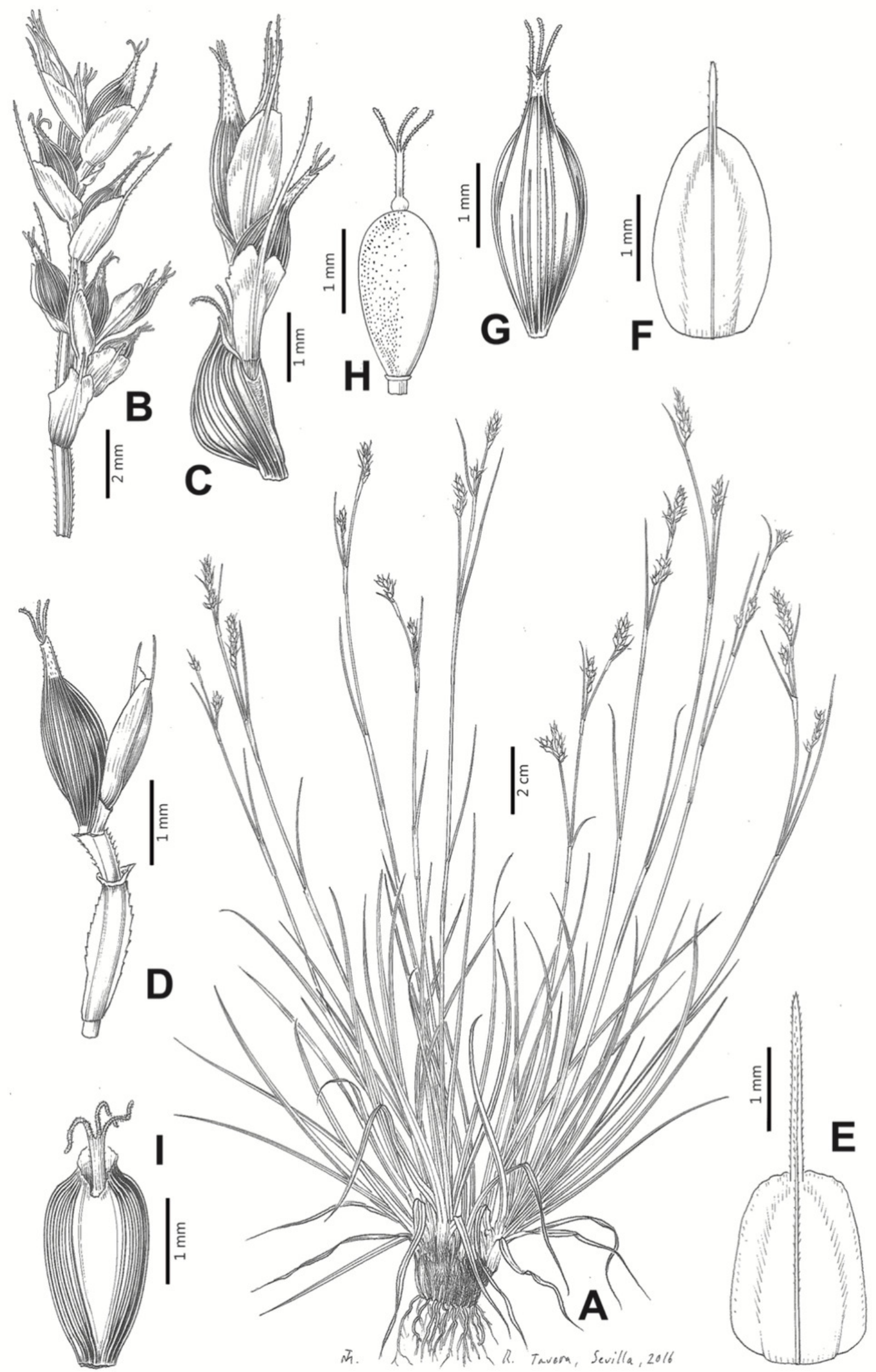


Figure 12

Illustration of Carex burkei

(A) General aspect of the plant. (B) Utriculiform cladoprophyll. (C) Female glume. (D) Male glume. (E) Unisexual utricle. (F) Achene. Illustration by M. Sánchez-Villegas. 





Figure 13

Illustration of Carex capensis

(A) General aspect of the plant showing two fertile culms. (B) Utriculiform cladoprophyll. (C) Female glume. (D) Male glume. (E) Unisexual utricle. (F) Achene. Illustration by M. SánchezVillegas. 

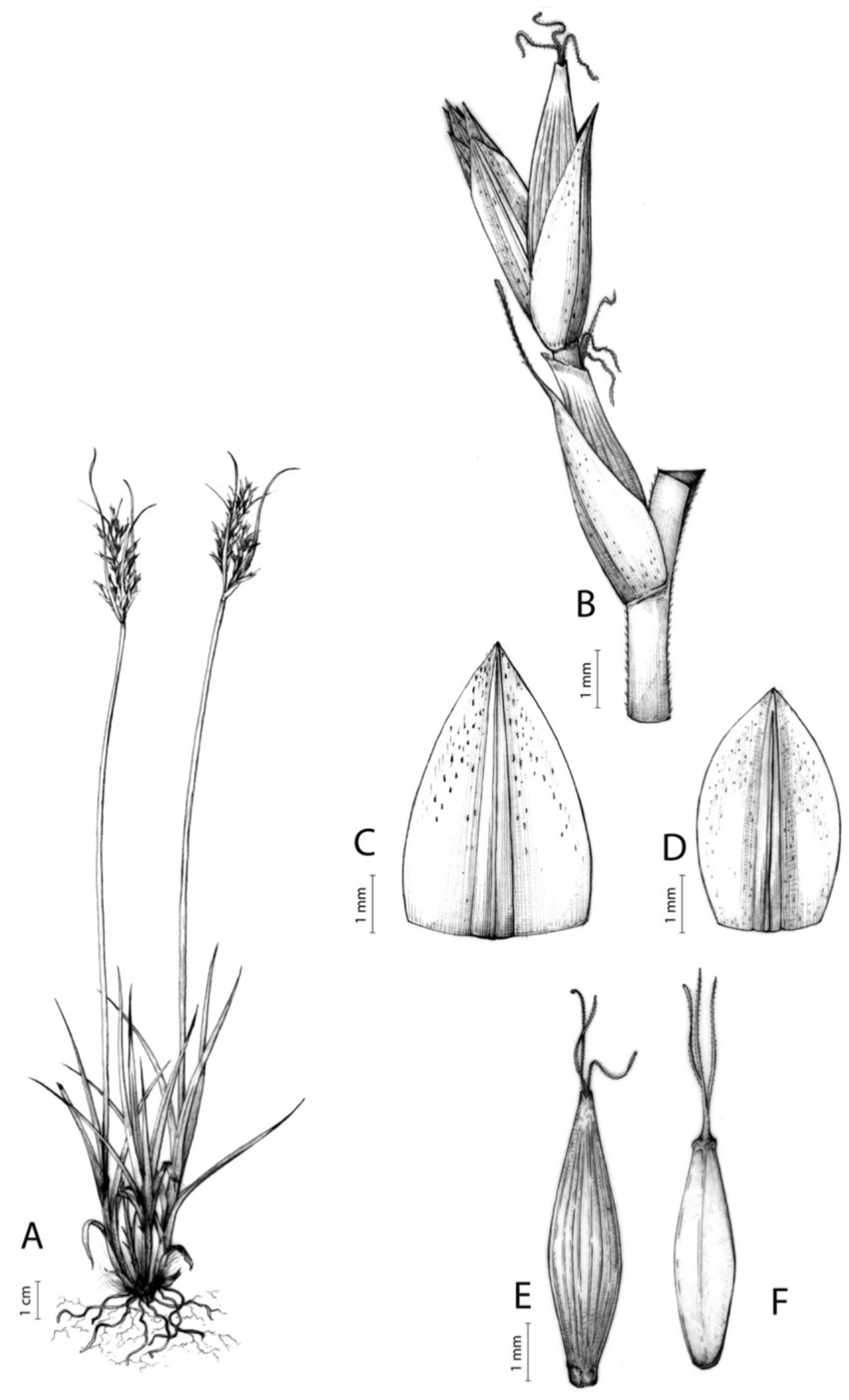

M. S. Villegas '20. 
Figure 14

Illustration of Carex distincta

(A) General aspect of two specimens. (B) Utriculiform cladoprophyll. (C) Female glume. (D) Male glume. (E) Unisexual utricle. (F) Achene. Illustration by M. Sánchez-Villegas. 


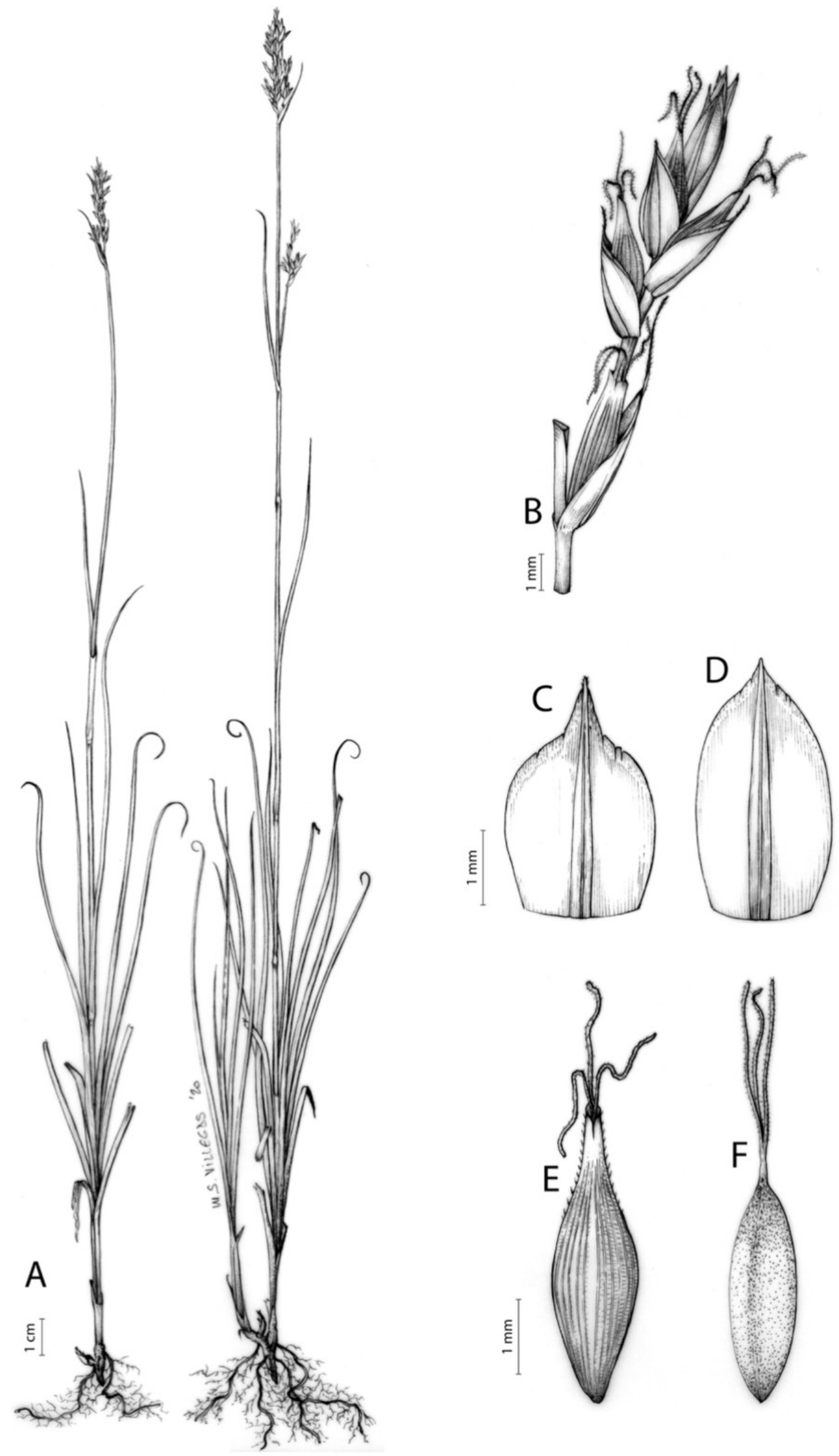

Peer) reviewing PDF | (2021:02:57694:1:1:NEW 25 Mar 2021) 


\section{Figure 15}

Distribution map of different species of Carex section Schoenoxiphium

(A) C. dregeana (red stars: references from Haines \& Lye (1983). black circles: studied

materials). (B) C. esenbekiana (C) C. gordon-grayii. (D) C. killickii. (E) C. kukkoneniana. (F) C. lancea. (G) C. ludwigii. Maps created with QGIS. 
A

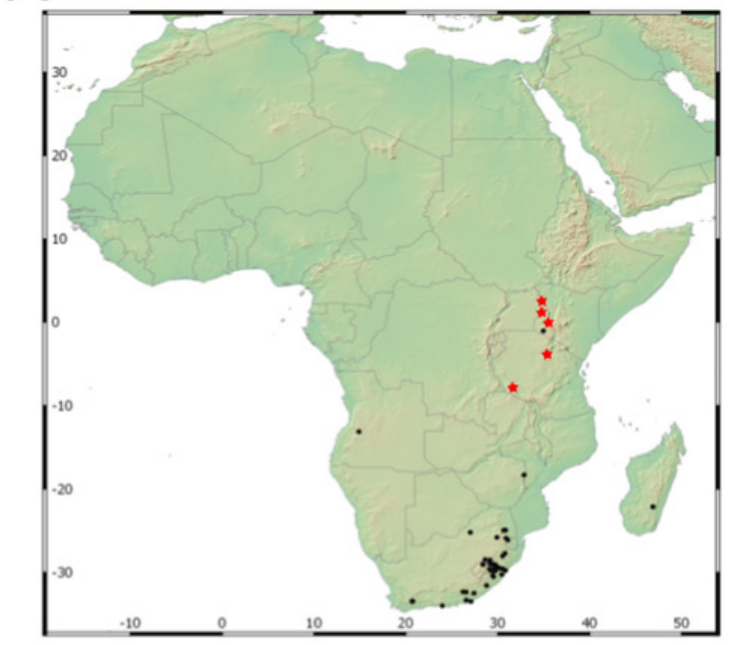

C

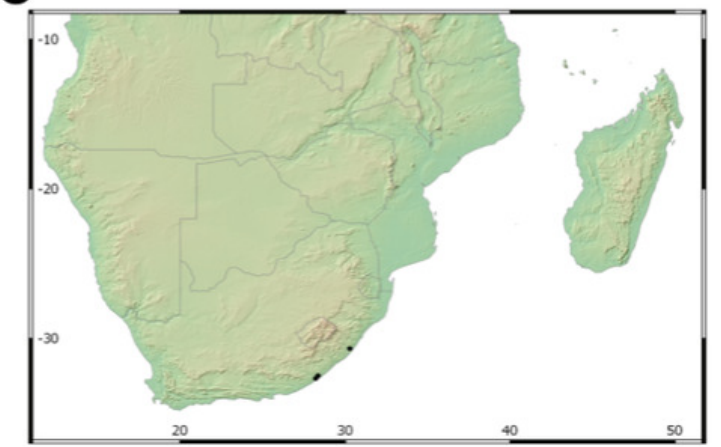

E

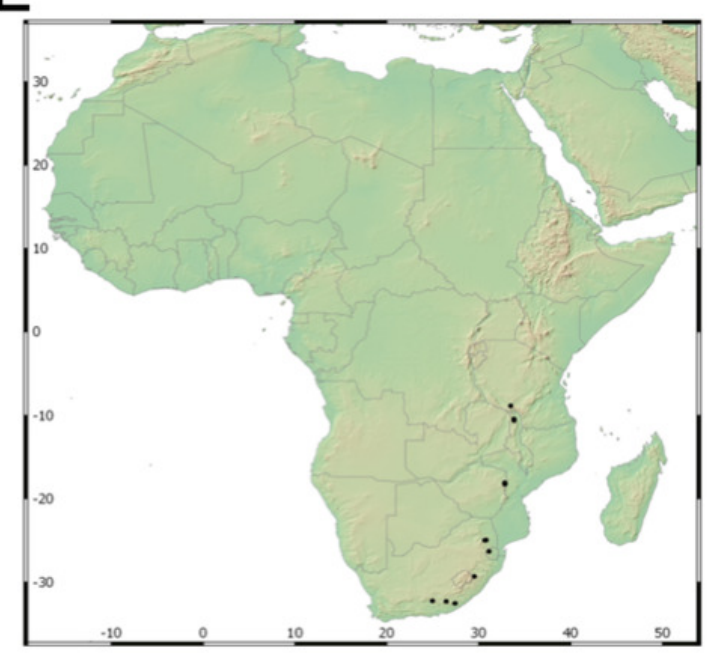

B

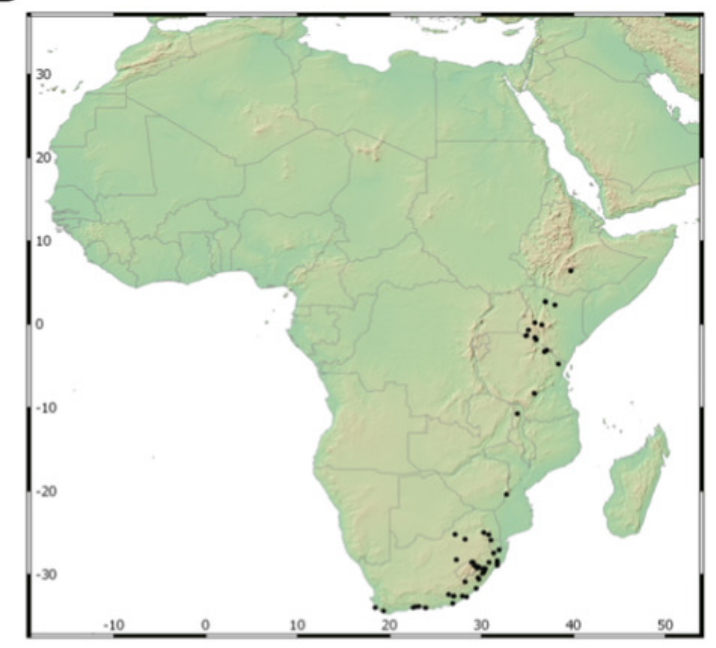

D

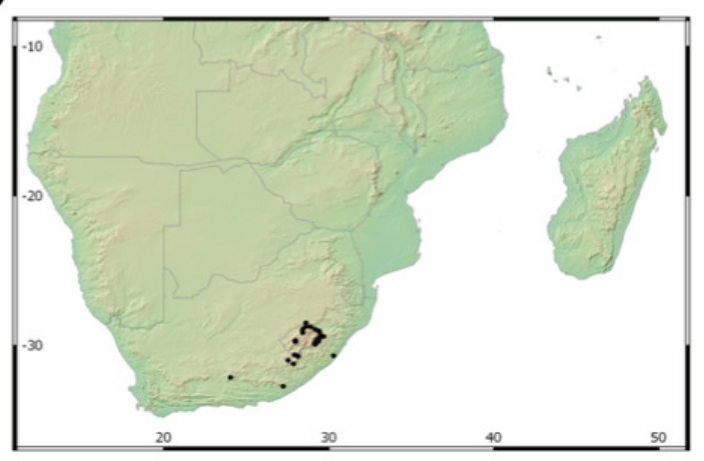

F

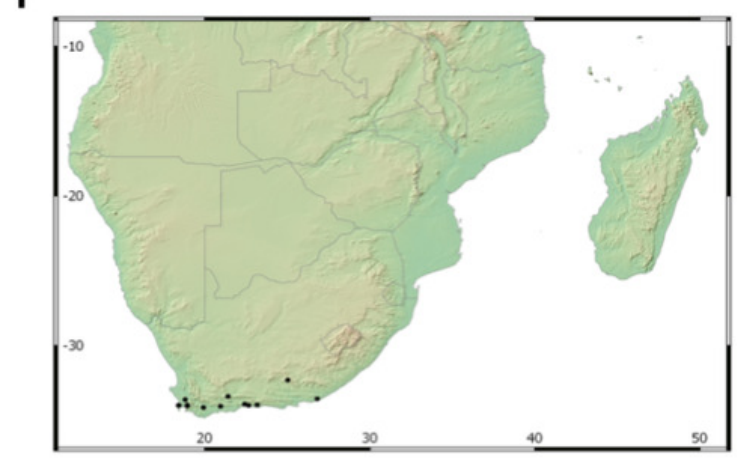

G

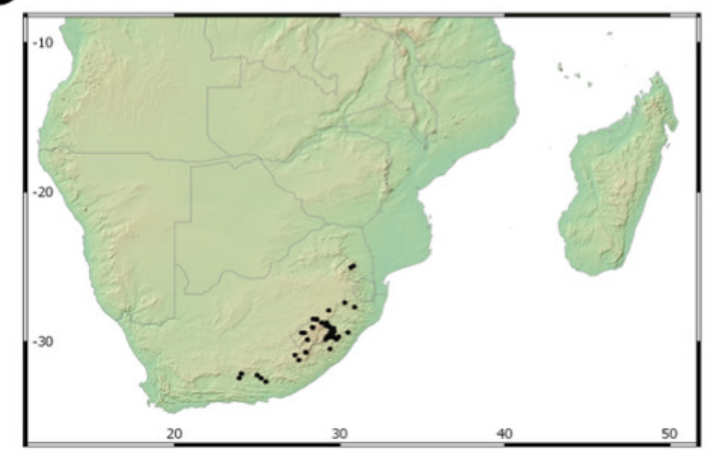


Figure 16

Illustration of Carex dregeana

(A) General aspect of the plant showing two fertile and one sterile culms. (B) Female glume.

(C) Male glume. (D) Unisexual utricle. (E) Achene. Illustration by M. Sánchez-Villegas. 


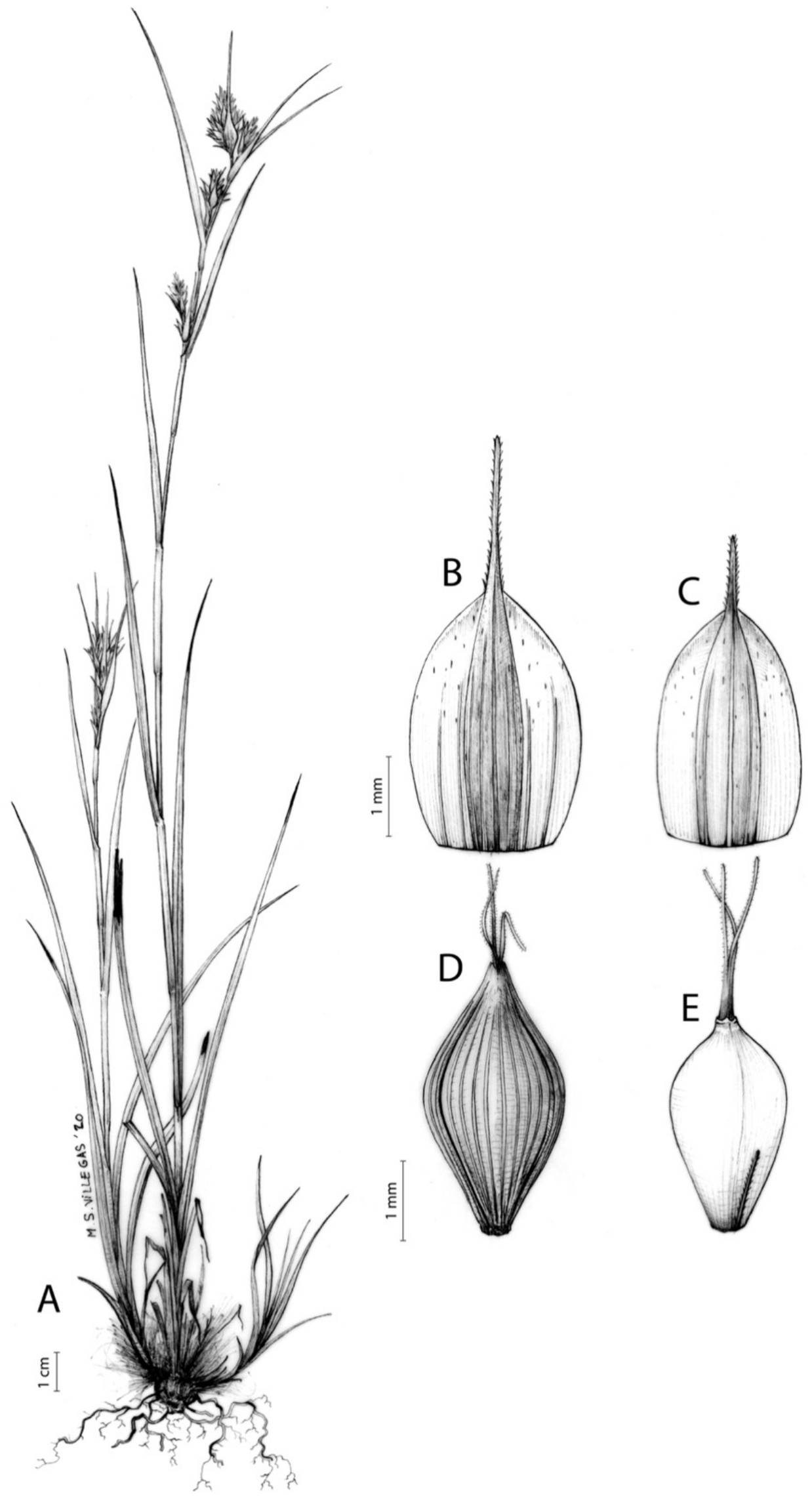

Peer] reviewing PDF | (2021:02:57694:1:1:NEW 25 Mar 2021) 
Figure 17

Morphology of different species of Carex section Schoenoxiphium

(A) C. dregeana. (B) C. esenbeckiana. (C) C. killickii. Photos by M. Luceño. 




\section{Figure 18}

Illustration of Carex esenbeckiana

(A) General aspect of the base of the plant and inflorescence. (B) Utriculiform cladoprophyll.

(C) Male glume. (D) Female glume. (E) Achene. (F) Unisexual utricle. (G) Fragment of a basal leaf. Illustration by M. Sánchez-Villegas. 


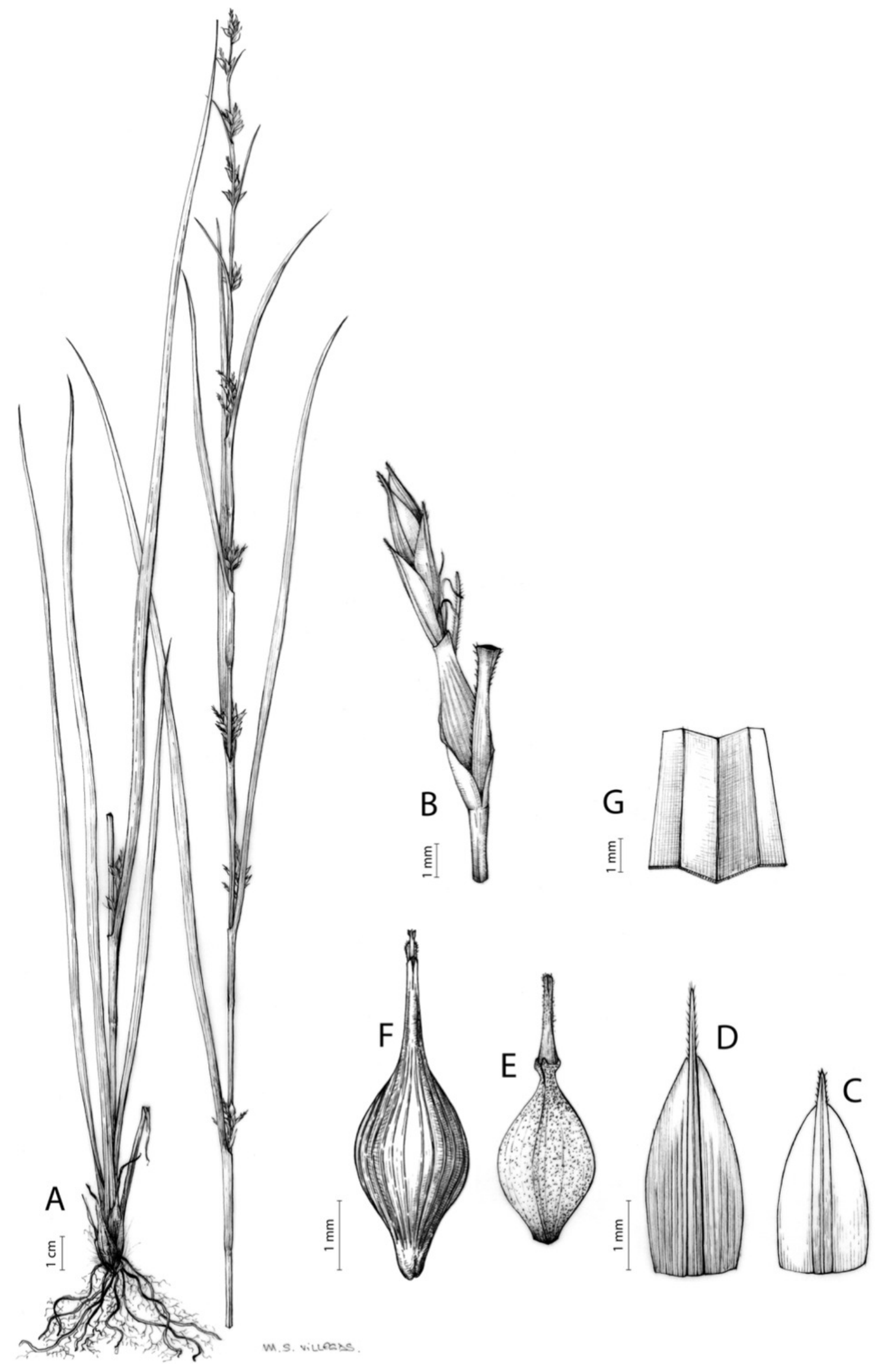

Peer] reviewing PDF | (2021:02:57694:1:1:NEW 25 Mar 2021) 


\section{Figure 19}

Illustration of Carex gordon-grayae

(A) General aspect of the base of the plant and inflorescence. (B) Utriculiform cladoprophyll.

(C) Female glume. (D) Male glume. (E) Unisexual utricle. (F) Achene. Illustration by M.

Sánchez-Villegas. 


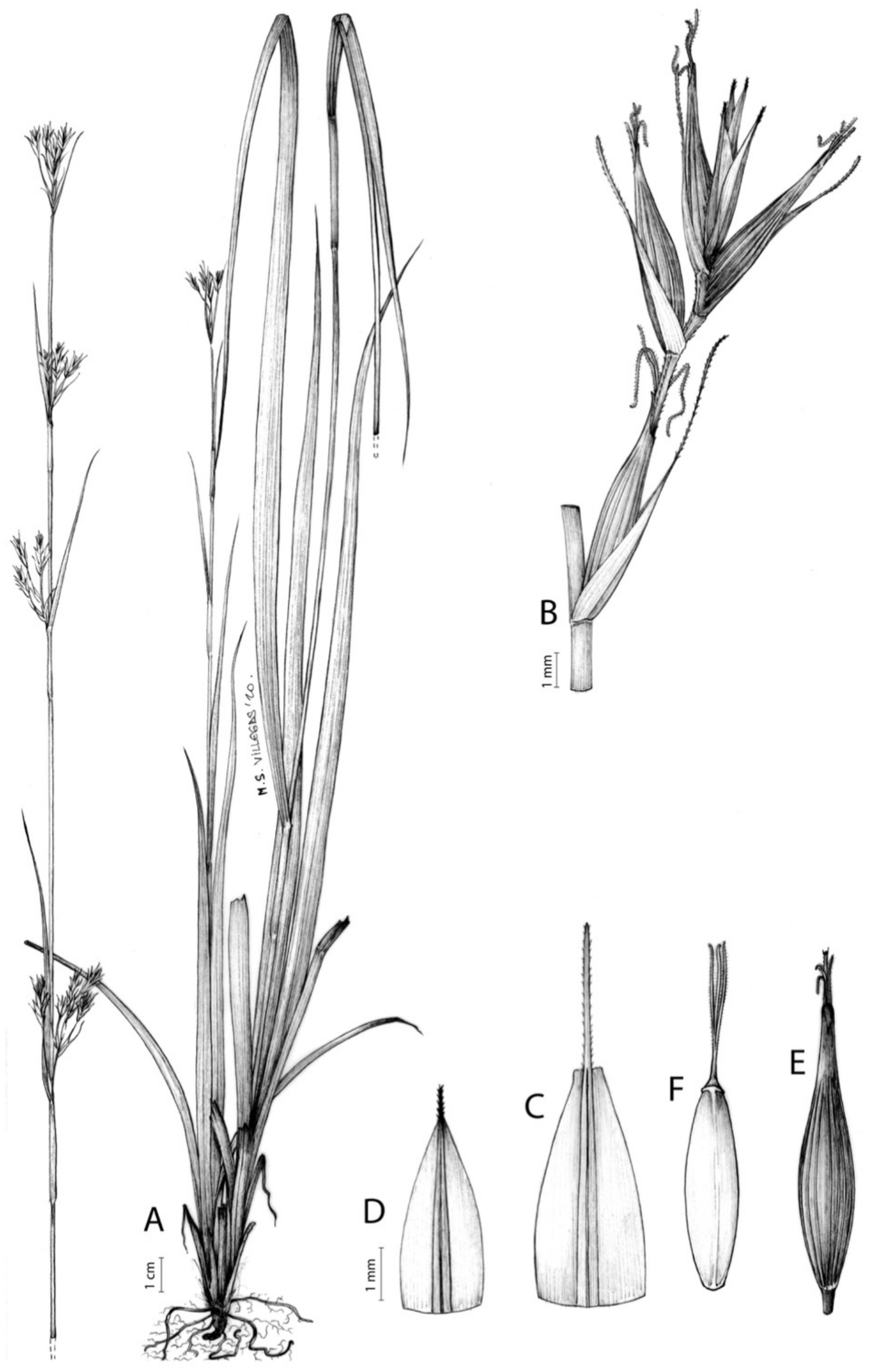

Peer) reviewing PDF | (2021:02:57694:1:1:NEW 25 Mar 2021) 
Figure 20

Holotype of Carex gordon-grayae

Photo of voucher NU-2643 deposited at University of Natal (South Africa). Photo by M.

Míguez. 







\section{Figure 21}

Illustration of Carex killickii

(A) General aspect of the common morphotype. (B) Utriculiform cladoprophyll. (C) Female glume. (D) Male glume. (E) Unisexual utricle of the common morphotype. (F) Achene. (G) General aspect of the summit morphotype. $(\mathrm{H})$ Unisexual utricle of the summit morphotype. (I) Inflorescence of the summit morphotype. Illustration by M. Sánchez-Villegas. 

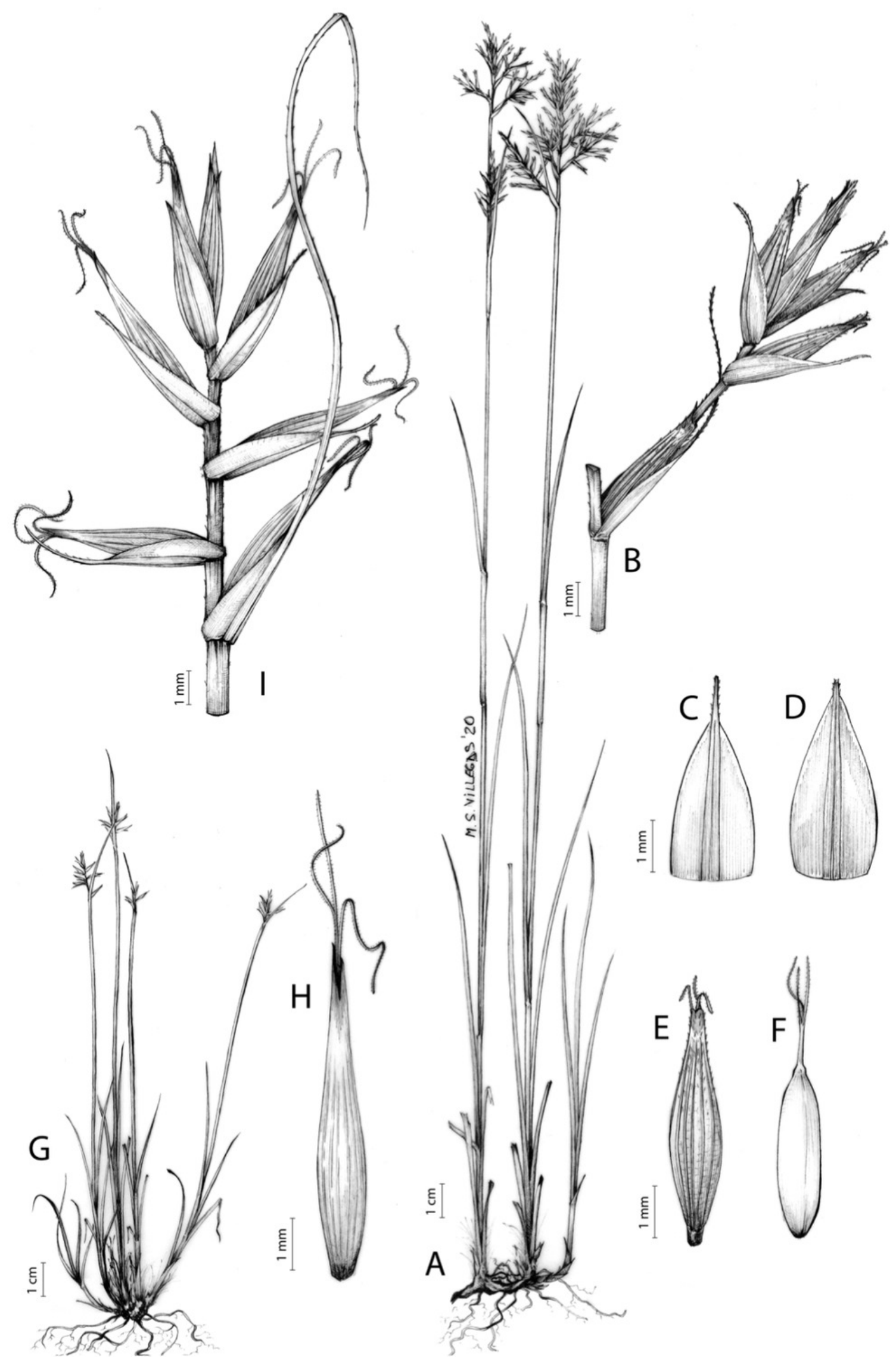
Figure 22

Illustration of Carex kukkoneniana

(A) General aspect of the plant and inflorescence. (B) Utriculiform cladoprophyll. (C) Female glume. (D) Male glume. (E) Unisexual utricle. (F) Achene. Illustration by M. Sánchez-Villegas. 





Figure 23

Illustration of Carex lancea

(A) General aspect of the base of the plant and intrescence. (B) Glumiform cladoprophyll axilating a male spikelet and three unisexual utricles. (C) Female glume. (D) Male glume. (E) Unisexual utricle. (F) Achene. Illustration by M. Sánchez-Villegas. 

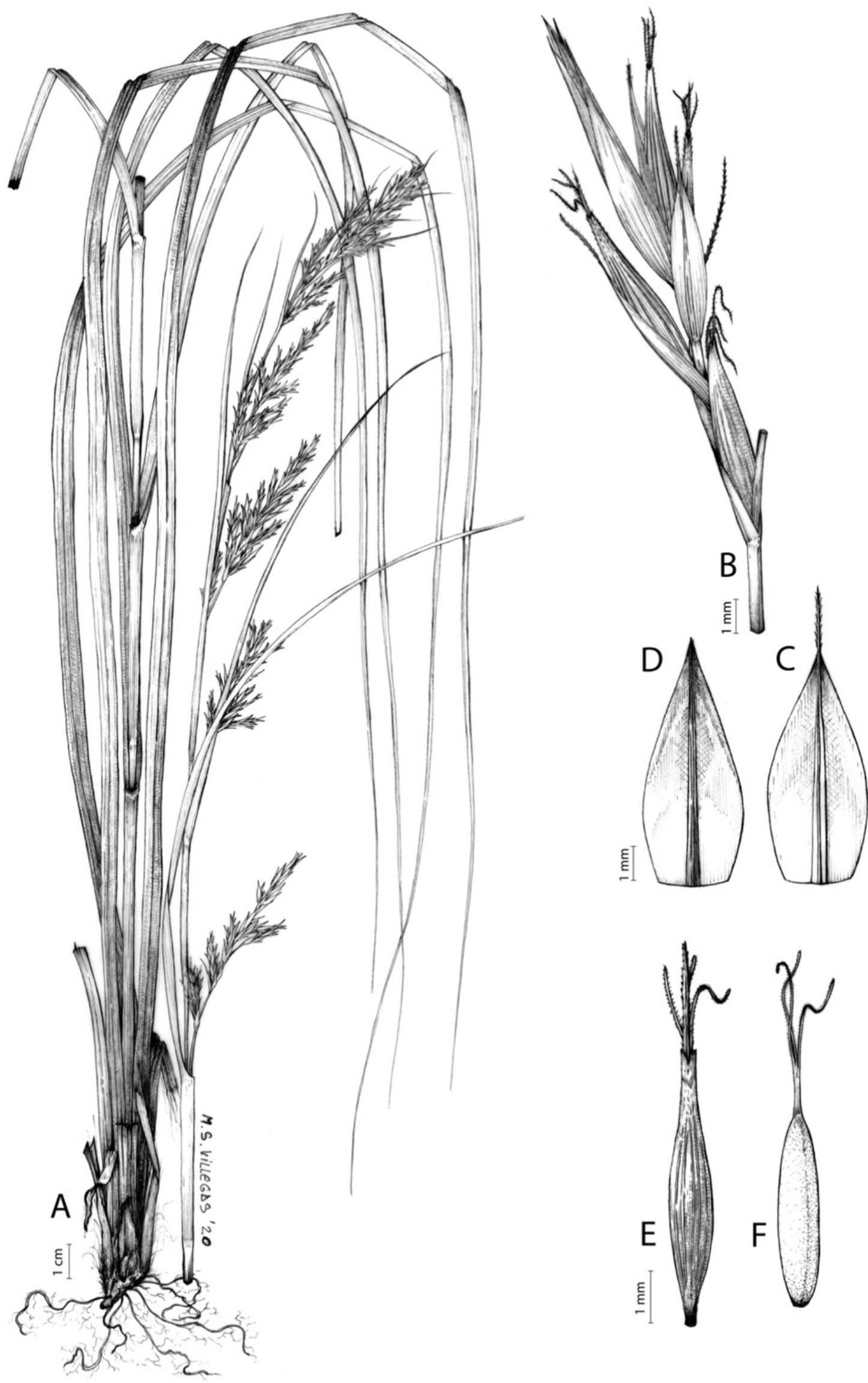
Figure 24

Morphology of different species of Carex section Schoenoxiphium

(A) C. lancea. (B) C. Iudwigii. (C) C. multispiculata. Photos by M. Luceño. 


Figure 25

Illustration of Carex ludwigii

(A) General aspect of a fertile culm showing five nodding partial inflorescences. (B) Utriculiform cladoprophyll. (C) Female glume. (D) Male glume. (E) Abaxial view of an unisexual utricle. (F) Lateral view of an unisexual utricle. (G) Achene. Illustration by M. Sánchez-Villegas. 


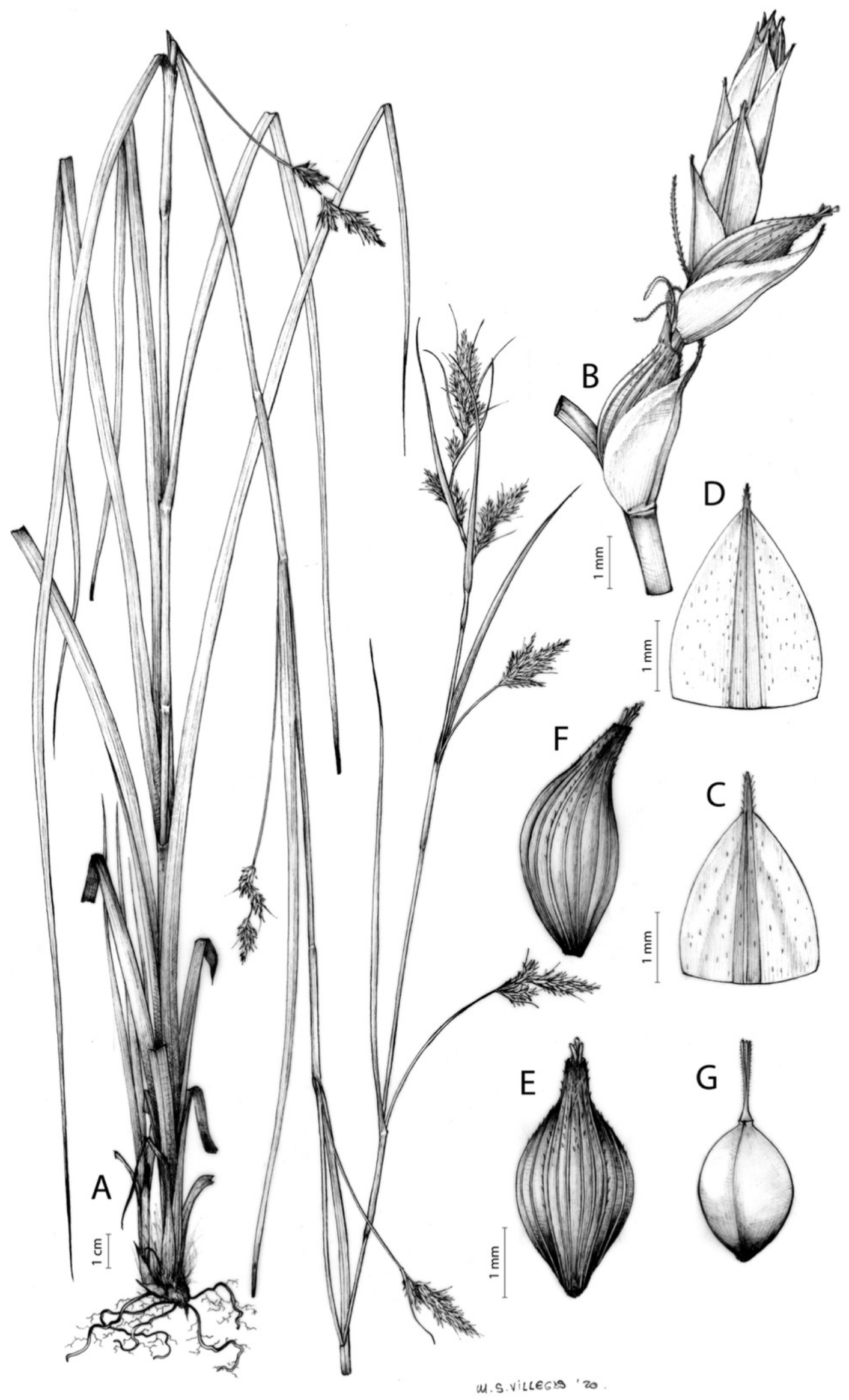


Figure 26

Distribution map of different species of Carex section Schoenoxiphium.

(A) C. multispiculata (B) C. perdensa. (C) C. pseudorufa. (D) C. schweickerdtii. (E) C. sciocapensis. (F) C. spartea. Maps created with QGIS. 
A



C

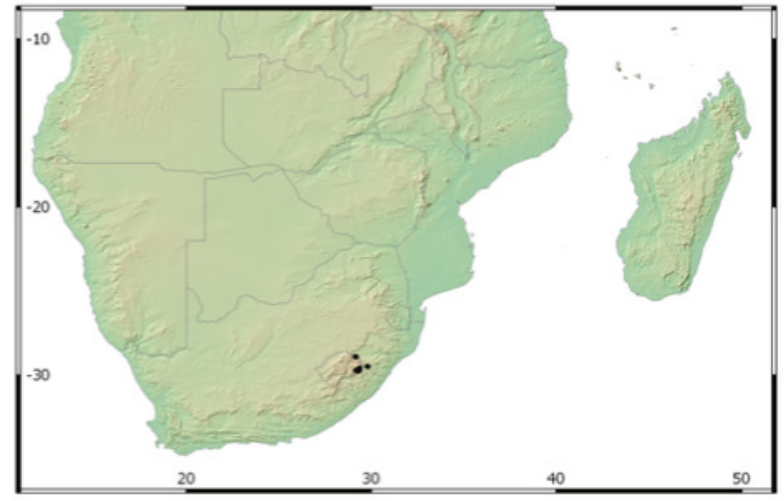

E



B



D

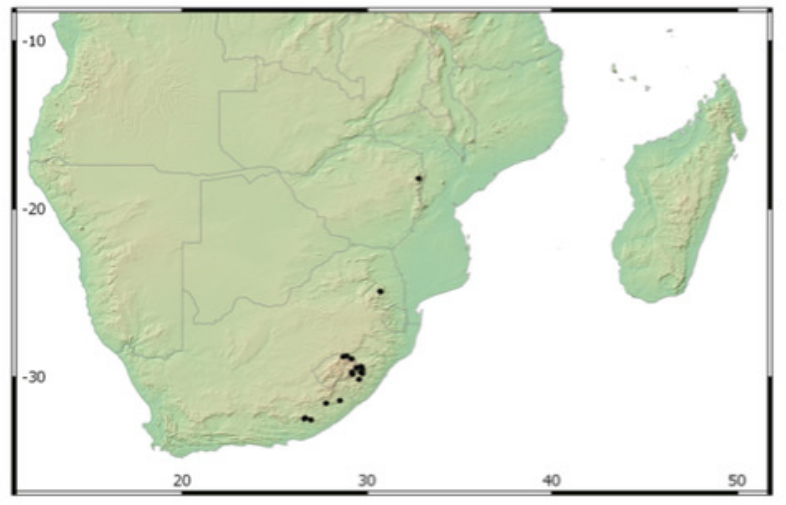

F

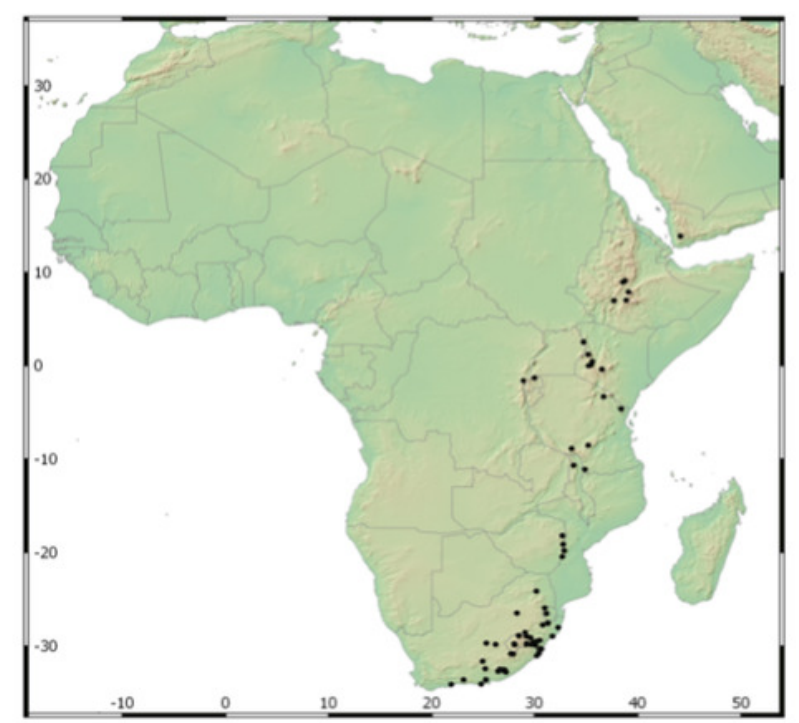


Figure 27

Illustration of Carex multispiculata

(A) General aspect of the base of the plant and inflorescence. (B) Utriculiform cladoprophyll.

(C) Female glume. (D) Male glume. (E) Unisexual utricle. (F) Achene. Illustration by M.

Sánchez-Villegas. 




Peer) reviewing PDF | (2021:02:57694:1:1:NEW 25 Mar 2021) 
Figure 28

Illustration of Carex perdensa

(A) General aspect of the plant. (B) Partial inflorescence. (C) Female glume. (D) Male glume.

(E) Unisexual utricle. (F) Achene. Illustration by M. Sánchez-Villegas. 

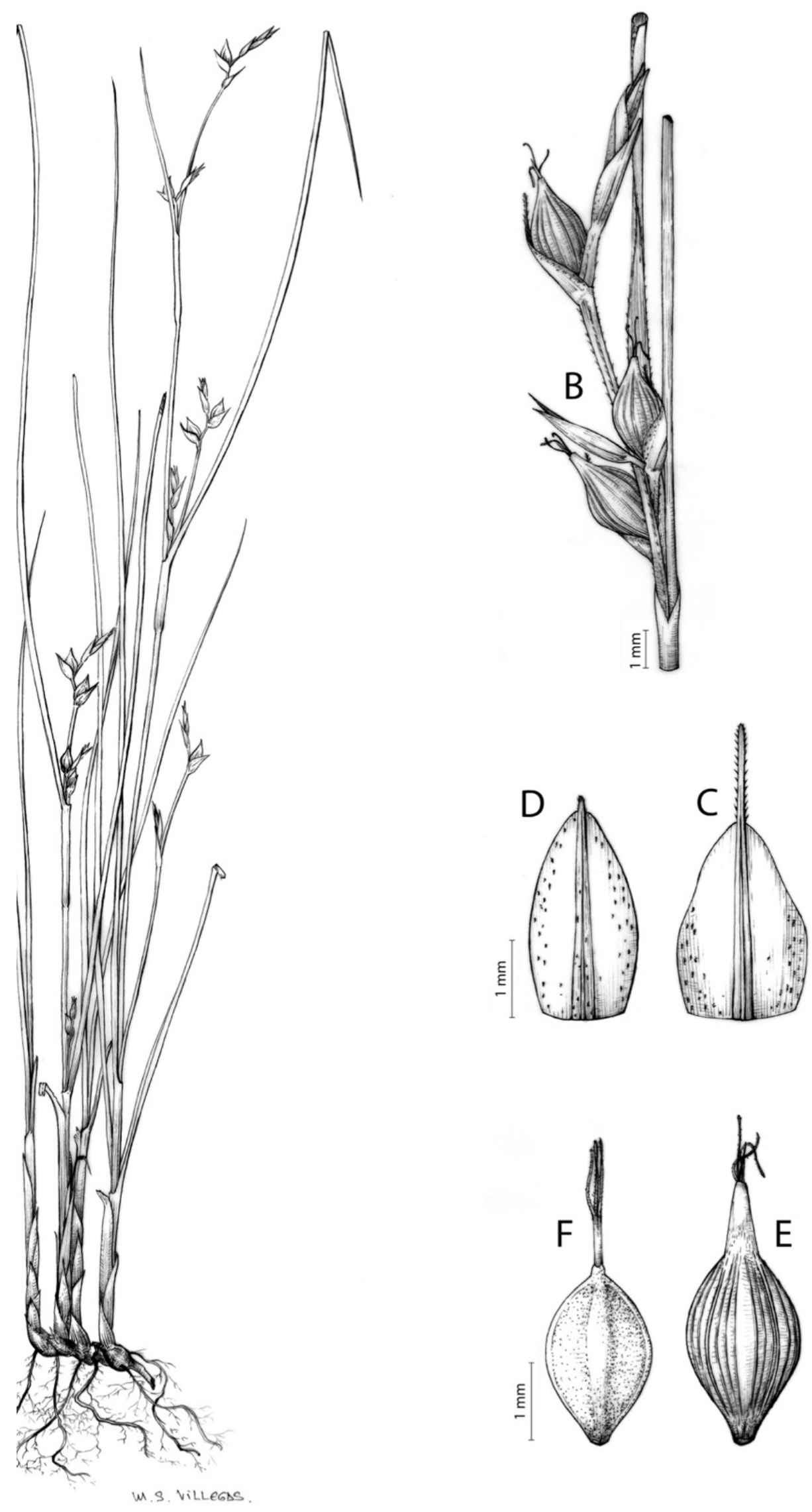

Peer) reviewing PDF | (2021:02:57694:1:1:NEW 25 Mar 2021) 
Figure 29

Morphology of di $\square$ erent species of Carex section Schoenoxiphium

(A) C. perdensa. (B) C. pseudorufa. Photos by M. Luceño. 

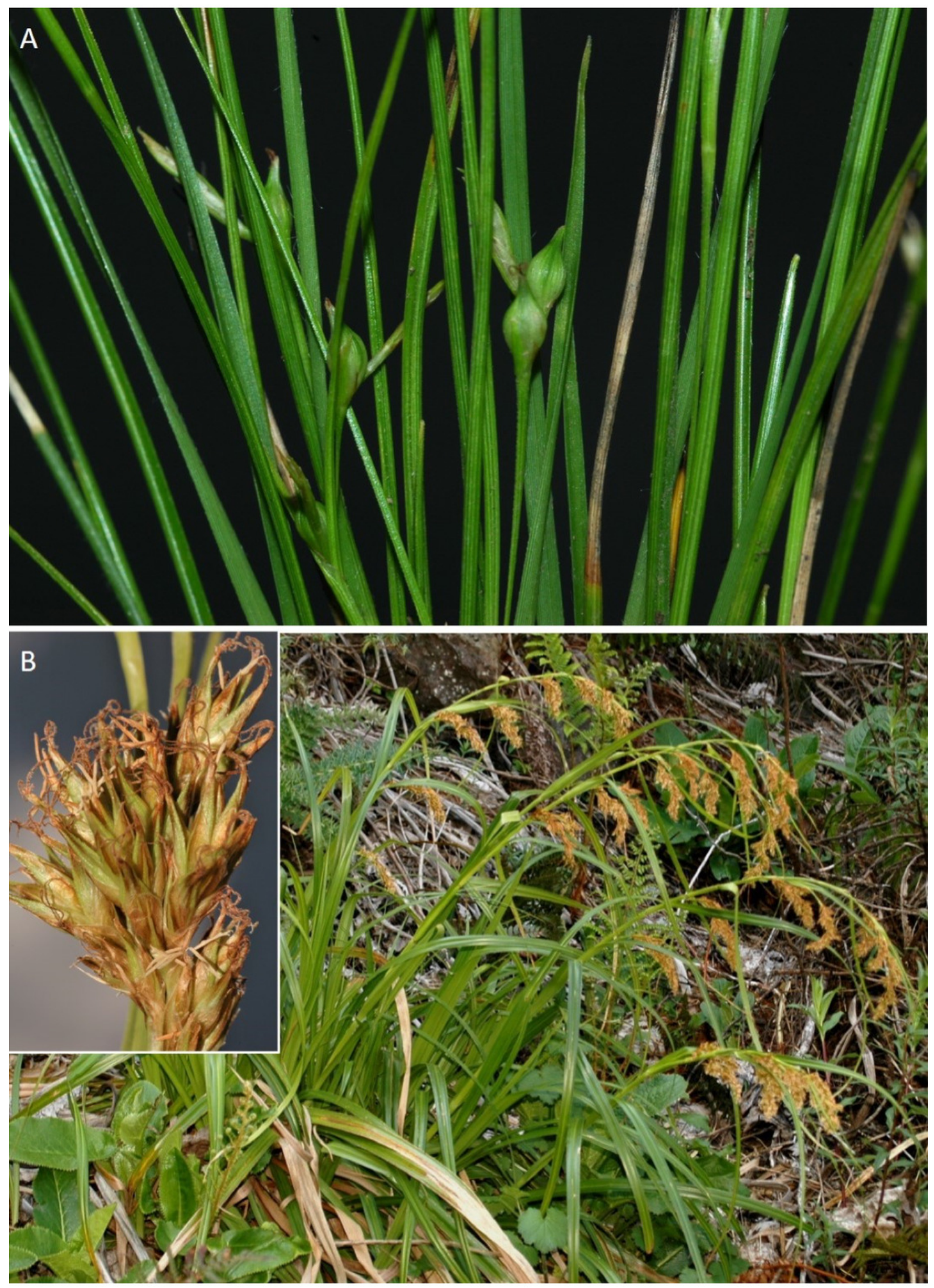
Figure 30

Illustration of Carex pseudorufa

(A) General aspect of the plant showing several nodding partial inflorescences. (B) Bisexual utricle. (C) Female glume. (D) Male glume. (E) Unisexual utricle. (F) Achene. Illustration by M. Sánchez-Villegas. 


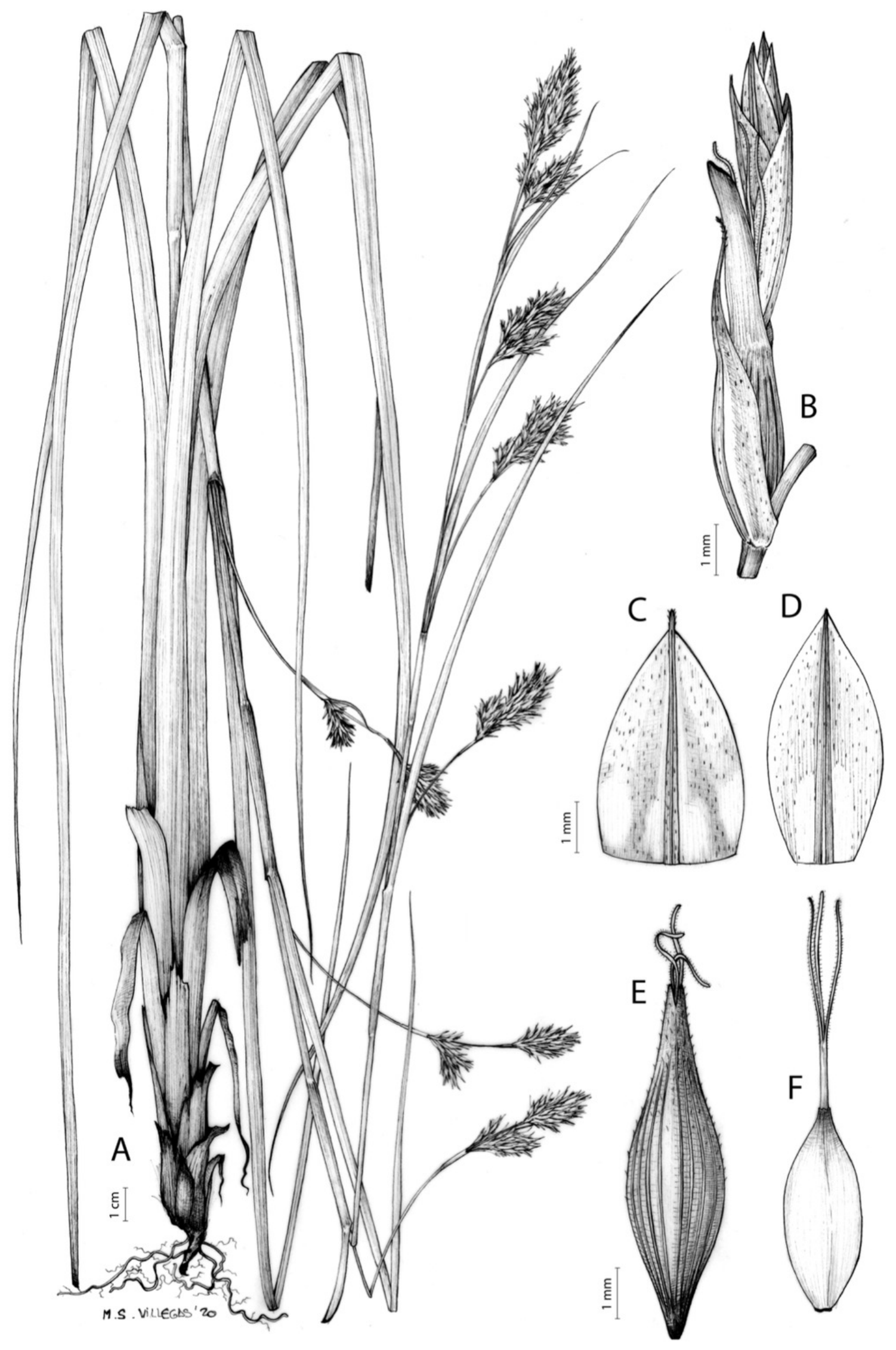


Figure 31

Illustration of Carex schweickerdtii

A) General aspect of the plant showing one mature fertile culm (left) and one young fertile culm (right). (B) Utriculiform cladoprophyll. (C) Female glume. (D) Male glume. (E) Unisexual utricle. (F) Achene. (G) Fragment of a leaf. Illustration by M. Sánchez-Villegas. 


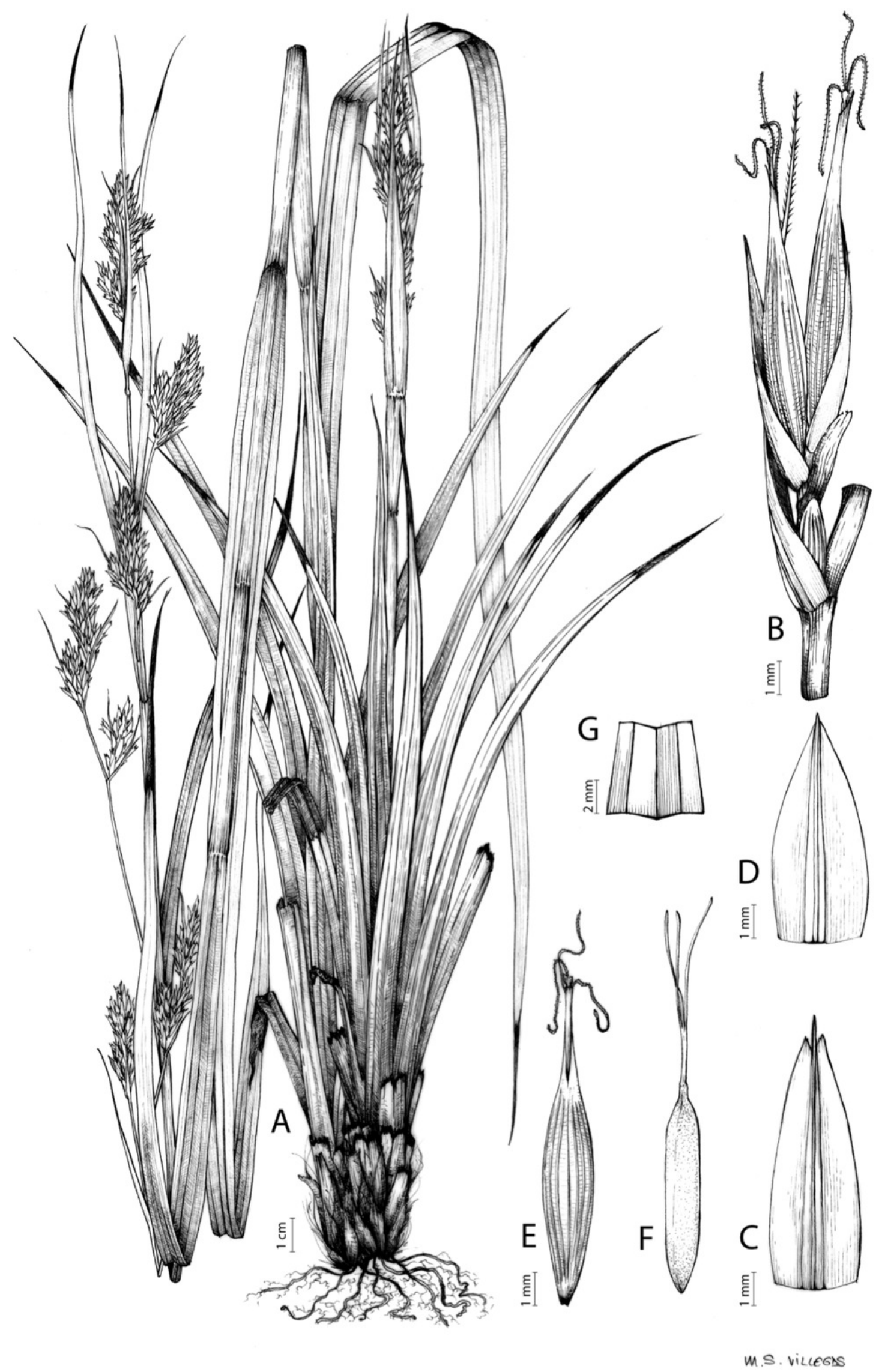


Figure 32

Morphology of different species of Carex section Schoenoxiphium

(A) C. schweickerdtii. (B) C. sciocapensis. (C) C. spartea. Photos by M. Luceño. 

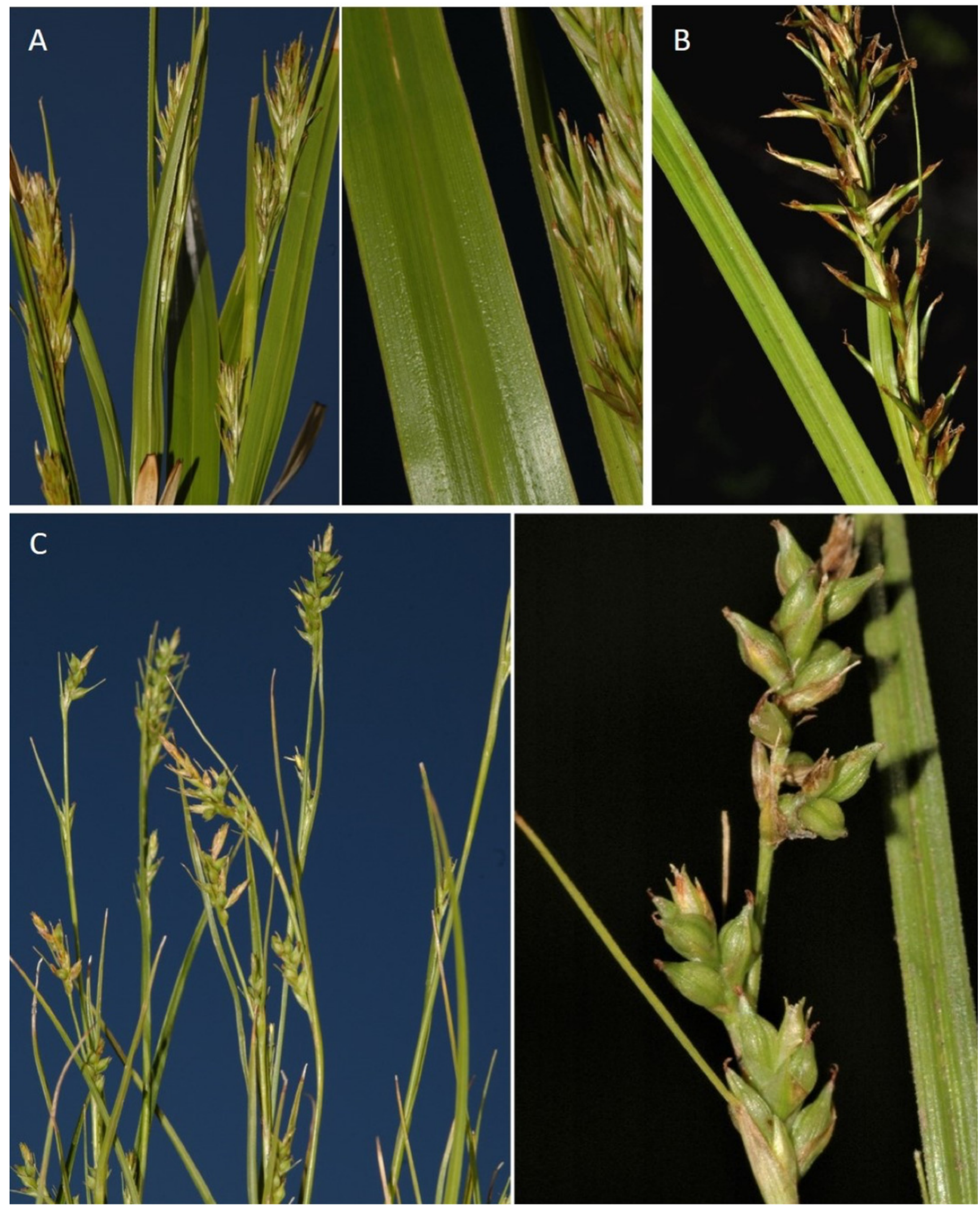
Figure 33

Illustration of Carex sciocapensis

(A) General aspect of the base of the plant and fertile culm showing the inflorescence. (B) Utriculiform cladoprophyll. (C) Female glume. (D) Male glume. (E) Unisexual utricle. (F) Achene. Illustration by M. Sánchez-Villegas. 


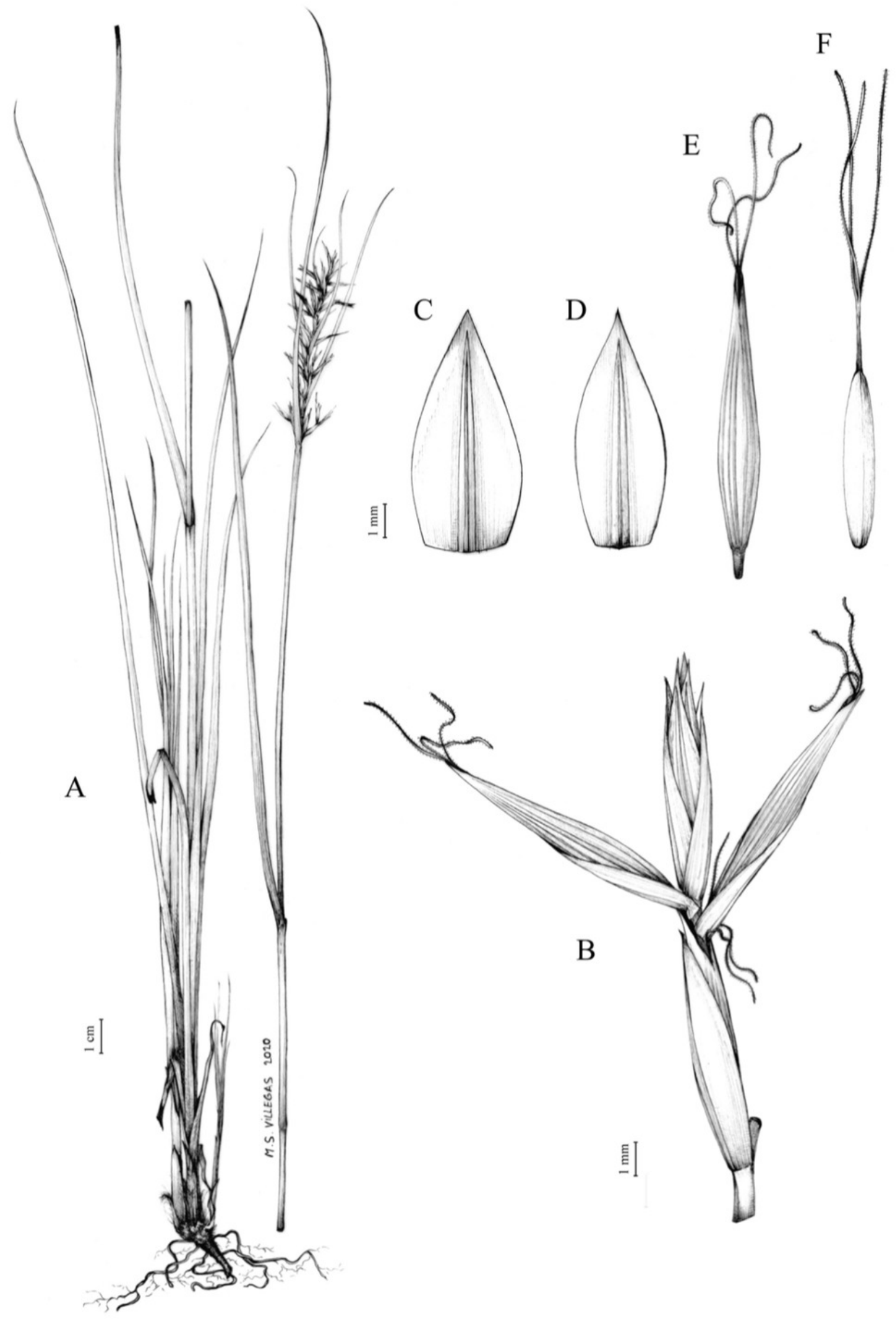

Peer) reviewing PDF | (2021:02:57694:1:1:NEW 25 Mar 2021) 
Figure 34

Illustration of Carex spartea

(A) General aspect of the plant showing a long rhizome internode, an sterile culm and two fertile culms. (B) Utriculiform cladoprophyll. (C) Female glume. (D) Male glume. (E) Unisexual utricle. (F) Achene. Illustration by M. Sánchez-Villegas. 

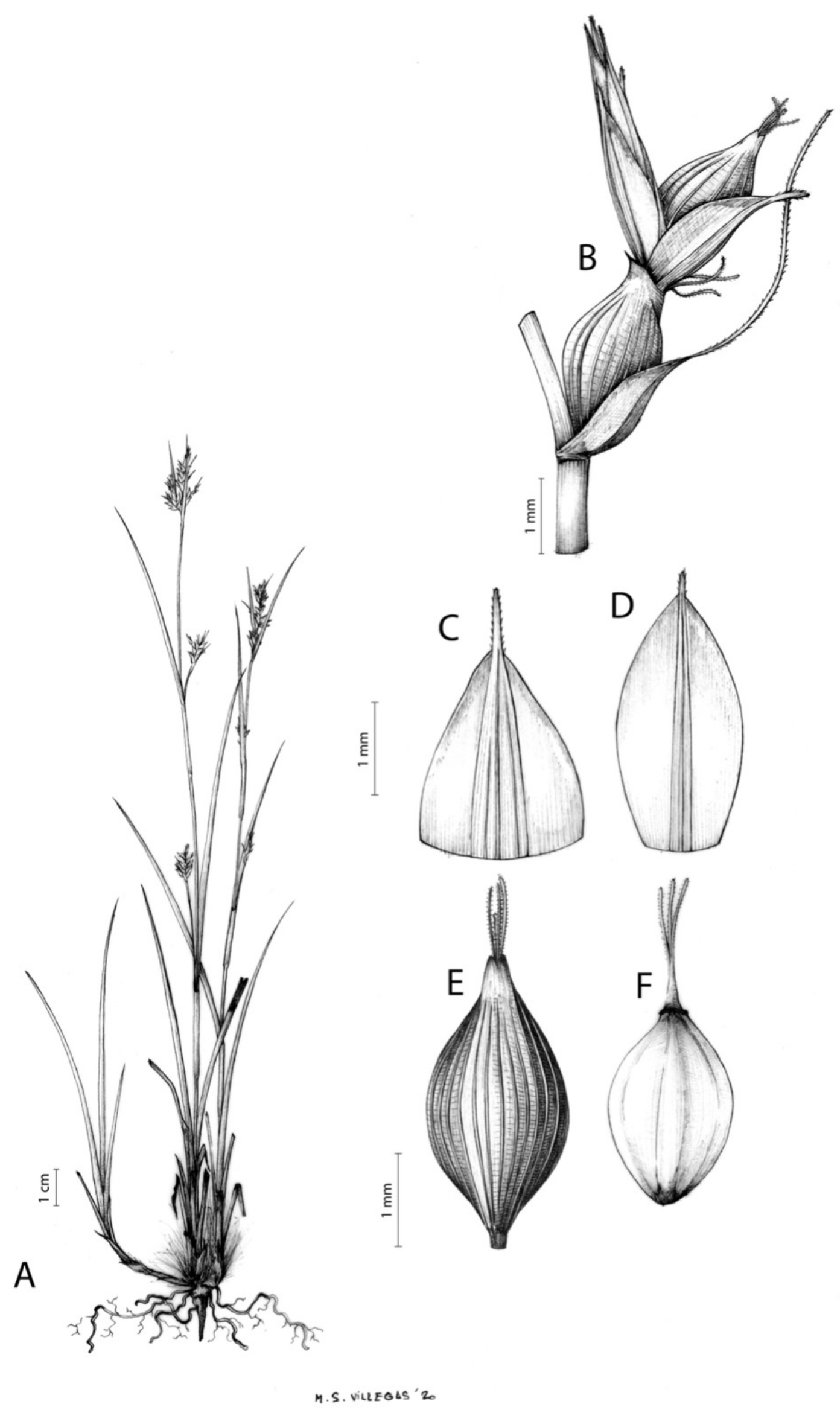

Peer) reviewing PDF | (2021:02:57694:1:1:NEW 25 Mar 2021) 